$\mathrm{KCP}-613-4253$

Distribution Category UC-706

$\mathrm{KCP}--61.3-4253$

DE91 001036

PHYSICAL FROPERTIES OF CONTAMINATED

TRICHLOROETHYLENE AND

$1,1,1$-TRI CHLOROETHANE

R. D. Holt

Published October 1990

Topical Report

R. D. Holt, Project Leader

Project Team:

C. R. Cooperrider

F. J. Kamler

Technical Communications

Kansas City Division

\title{
Allied-Signal Aerospace Company
}


PHYSICAL PROPERTIES OF CONTAMINATED TRICHLOROETHYLENE AND $1,1,1$-TRICHLOROETHANE

KCP-613-4253, Topical Report, Published October 1990

Prepared by R. D. Holt

The specific gravity, volume change, dielectric constant, dissipation factor, boiling point, and nonvolatile residue carryover during distillation was measured for various contamination levels of rosin in trichloroethylene and l,1,1-trichloroethane. Solvent stabilizers and the vapor pressure of solvents were examined.

The effects of unknown contamination in solvents from manufacturing departments were measured. The theoretical effects of oil contamination on the boiling point are discussed.

SW:Ijs

TRI/be 
CONTENTS

Section Page

SUMMARY. . . . . . . . . . . . . . . . . . . . 11

DISCUSSION • . . . . . . . . . . . . . . . . . . 13

SCOPE AND PURPOSE. . . . . . . . . . . . . . . . 13

ACTIVITY . . . . . . . . . . . . . . . . 13

Background . . . . . . . . . . . . . . . . 13

Pure Solvent and contaminant properties. . . . . . . 14

Solvent Stabilizers. . . . . . . . . . . . . 14

Specific Gravity . . . . . . . . . . . . . . 17

Volume Change. . . . . . . . . . . . . . . 24

Dielectric constant. . . . . . . . . . . . . 26

Dissipation Factor . . . . . . . . . . . . . 29

Boiling Point. . . . . . . . . . . . . . . 31

Nonvolatile Residue. . . . . . . . . . . . . 43

Vapor Pressure . . . . . . . . . . . . . . . . . 44

Eire Safety. . . . . . . . . . . . . . . 48

Health Safety. . . . . . . . . . . . . . . 4 49

ACCOMPLISHMENTS. • . . . . . . . . . . . . . . . . . 49

FUTURE WORK. . . . . . . . . . . . . . . 50

REFERENCES . . . . . . . . . . . . . . . . . 53 APPENDICES

A. ELECTRICAL PROPERTY MEASUREMENTS OF AS-RECEIVED AND ROSIN-CONTAMINATED TRICHLOROETHYLENE AND

1,1,1-TRICHLOROETHANE. . . . . . . . . . . 55

B. BOILING POINT MEASUREMENTS OF AS-RECEIVED AND

ROSIN-CONTAMINATED TRICHLOROETHYLEND AND

$1,1,1$-TRI CHLOROETHANE. . . . . . . . . . . . 


\section{ILLUSTRATIONS}

Figure

Page

Gas Chromatogram of Trichloroethylene As-Received, Distilled, and Undistilled...

2

Gas Chromatogram of 1,1,1-Trichloroethane As-Received, Distilled, and Undistilled...

Specific Gravity Versus Rosin Contamination Levels for $\operatorname{Trichloroethylene}$ and $1,1,1-\mathrm{Tr}$ ichloroethane at $25^{\circ} \mathrm{C}$. . . . . .

Volume Change Versus Rosin Contamination Levels for Trichloroethylene and

1,1,1-Trichloroethane at $25^{\circ} \mathrm{C}$. . . . . .

Dielectric Constant Versus Rosin Contamination Levels for Trichloroethylene and $1,1,1-T r i c h l o r o e t h a n e$ at $25^{\circ} \mathrm{C}$. . . . . .

Dissipation Factor Versus Rosin Contamination Levels for Trichloroethylene and 1,1,1-Trichloroethane... . . . . . .

Theoretical Boiling Point Versus Oil Contamination Levels for Trichloroethylene . . . . . . . . . . .

Theoretical Boiling Point Versus oil Contamination Levels for 1,1,1-Trichloroethane . . . . . . . . .

Boiling Point Change During Distillation of As-Received Trichzoroethylene . . . . . .

Boiling Point Change During Distillation of As-Received 1,1,1-Trichloroethane . . . .

Laboratory Apparatus for Boiling Point Measurements of Contaminated Solutions. . .

Boiling Point Versus Rosin Contamination Levels for Trichloroethylene. . . . . . . .

Boiling Point Versus Rosin Contamination Levels for 1,1,1-Trichloroethane. . . . . .

Nonvolatile Residue Carried over in the Distillation Process of Technical Grade Trichloroethylene and $1,1,1-T r i c h l o r o e t h a n e$ 


\section{TABLES}

Number

Page

1

Typical Properties of Trichloroethylene and 1,1,1-Trichloroethane. . . . . . . . .

Specifications for Reagent Grade and Technical

Grade Solverit. . . . . . . . . .

Typical Properties of Rosin. . . . . . . .

Stabilizer Packages of Trichloroethylene, $1,1,1-T r i c h l o r o e t h a n e$, and

Perchloroethylene. . . . . . . . . . .

Gas Chromatographic Measurements of Solvent Stabilizers and Impurities . . . . . . .

Specific Gravity and Volume Change of TCE and TCA at Various Contamination Levels by

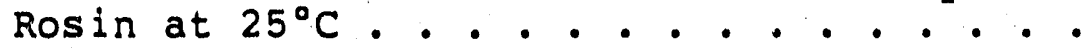

Dielectric Constant of Rosin-Contaminated Solvents . . . . . . . . . . . . . .

Theoretical Boiling Temperature for 5- to

30-Percent Oil-Contamination Levels of

Trichloroethylene and

1,1,1-Trichloroethane. . . . . . . .

Nonvolatile Carryover During Distillation of Contaminated Trichloroethylene and

1,1,1-Trichloroethane. . . . . . . . .

10 Nonvolatile Carryover During Distillation of Contaminated Solutions From Various Manufacturing Departments Compared With Vendor Chemicals . . . . . . . . . .

11 Antoine Constants for Trichloroethylene and 1,1,1-Trichloroethane. . . . . . . .

Solvent Density and PPM Level for Various Temperatures of Air . . . . . . . . . .

Health and Safety Data for Solvents. . . . . 
A-1 : Dissipation Factor and Capacitance Measurements of As-Received TCE and TCE Contaminated With Rosin. . . . . . . . . . . . . . . .

Dissipation Factor and Capacitance Measurements of As-Received TCA and TCA Contaminated With Rosin. . . . . . . . . . . . . . . .

A-3 Dissipation Factor and Capacitance Measurements of Solutions with Unknown Contamination Type . . . . . . . . . . . . . . .

B-1 Boiling Point Measurements of As-Received and Rosin-Contaminated TCE According to ASTM D 1078. . . . . . . . . . . . . .

B -2

Boiling Point Measurements of As-Received and Rosin-Contaminated TCA According to ASTM D 1078. . . . . . . . . . . .

$13-3$

Boiling Point Measurements of As-Received TCE an I TCA Using $250 \mathrm{~mL}$ of Solution . . . . .

B-4

Boiling Point Measurements of As-Received and Rosin-Contaminated TCE With the Thermometer in the Vapor Zone. . . . . . . . . . . .

Boiling Point Measurements of As-Received and Rosin-Contaminated TCE With the Thermometer in the Solution. . . . . . . . . . . . .

Boiling Point Measurements of As-Received and Rosin-Contaminated TCA With the Thermometer in the Vapor Zone . . . . . . . . . . . . . Rosin-Contaminated TCA with the Thermometer in the solution... . . . . . . . . . . 
The physical properties of trichloroethylene (TCE) and 1,1,1-trichloroethane (TCA) contaminated with rosin were characterized. The specific gravity, dielectric constant, dissipation factor, boiling point, and nonvolatile residue carryover during distillation were measured for various contamination level.s of rosin in TCE and TCA.

The boiling point of the solvents is affected more by the solvent stabilizers than by rosin at rosin contamination levels of less than 30 percent by weight. In the 35 and greater percentage contamination range, rosin has the dominant effect on the solution boiling point. Specific gravity changes sufficiently with contamination so that it can be used to measure the amount of rosin in the solvent. The dielectric constant of rosincontaminated TCE was discovered to be very constant over the entire range of contamination levels, 0 to 50 percent by weight. The dielectric constant of pure and contaminated TCA is significantly different from that of TCE. This difference can be used to easily and quickly identify an unknown solvent type for solvent waste recycling.

The data obtained on this project were essential to support the design of the new vapor-containing cleaning system; the system will meet the demands of new environmental and health restrictions and maintain the high level of cleaning needed on electronic assemblies. These data eliminated the unknowns in the area of contamination carryover during distillation and in physical property changes that could be monitored to indicate solvent contamination level.

The effects of unknown contamination in solvents from manufacturing departments were measured. This included measuring the boiling point, nonvolatile content, nonvolatile carryover during distillation, dissipation factor, and dielectric constant.

The effects of oil contamination on the boiling point were theoretically examined. Laboratory analysis of solvents contaminated with oils is an important effort that should be completed to support the cleaning of machined parts. No future work in characterization of contaminated solvents is planned as part of this project. 


\section{DISCUSSION}

\section{SCOPE AND PURPOSE}

The purpose of this project was to determine the physical properties of contaminated trichloroethylene (TCE) and 1,1,1-trichloroethane (TCA). This project was in support of the design of the new vapor-containing cleaning system to meet the demands of new environmental and health restrictions and maintain the high level of cleaning needed on electronic assemblies.

The scope of this project was limited to laboratory evaluation of rosin-contaminated solvents and a literature search for the effects of other contamination types. Two types of soldering flux were the cnly rosin sources investigated. The primary focus of this project was to provide data accurate enough to support the design of the new vapor-containing cleaning system. This work was accomplished during september and October 1988.

\section{ACTIVITY}

\section{Backoround}

The majority of electronic assemblies built at Allied-Signal Inc., Kansas City Division (KCD), are required by specification to be cleaned with chlorinated or fluorinated (chlorofluorocarbon) solvents. Evaluation of solvent cleaning has shown that TCE and TCA, which are chlorinated solvents, are the best solvents for removing flux and other organic contaminants found on electronic and mechanical assemblies. The coming severe restrictions or banning of fluorinated solvents (CFCs), - because of their detrimental effects on the ozone layer, make their use as cleaning agents less desirable. The toxicity and lowering of exposure limits on chlorinated solvents will restrict their use and require controlled cleaning techniques.

The need to continue to use these solvents to maintain adequate product cleanliness has prompted the design and development of a vapor-containing cleaning system. The initial goal for the cleaning system is to maintain the distilled solvent at a technical grade purity level. The ability to maintain the solvent at any specified quality level will be limited by the physical properties of the solvents and by the monitoring methods. The physical properties of contaminated solvents must be known before a cleaning system that distilis and recycles the solvent can be designed and built.

Theoretical analysis can estimate the amount of change in some properties of solvents with varying contamination levels, but the validity of any theoretical model must be established with labolatory data. Laboratory tests were performed at KCD to 
experimentally determine how the boiling point, specific gravity, volume, nonvolatile residue carried over auring distillation, dielectric constant, and dissipation factor change with different percent-by-weight levels of solder flux (rosin)contaminated solvent.

\section{Pure Solvent and Contaminant Properties}

The typical properties of TCE and TCA are given in Table 1. specifications for cleaning at $K C D$ typicaliy require reagent grade chlorinated solvents for spray cleaning applications and technical grade solvents for vapor-degreasing applications. The technical grade solvent specifications are similar to reagent grade solvents (Table 2 ).

The TCE used in all of the laboratory experiments in this report was from one 5-galion can of technical grade solvent. The TCA used in all the laboratory experiments was from one lot of: technical grade solvent supplied in 1 -galion glass containers.

Solder flux is the major contaminant on electronic assemblies. Flux is mainly rosin with isopropyl alcohol as a solvert carrier. Rosin is a solid separated from pine tree sap by distillation. The color of pure rosin is primarily a result of oxidation which turns it from water white clear to a dark brown." Ros in is 80-to 90-percent abeitic acid, with 10- to 15-percent pimaric acid. The boiling points of these resin acids are 250 and $282^{\circ} \mathrm{C}$, respectively.2 These resin acids and their isomers easily dissolve in chlorinated solvents, and this is the main reason why chlorinated solvents are so effective in removing rosin.

For soldering applications at $K C D$, flux rosin must meet three military specifications: MIL-F-14256, QQS-571, and LLL-R-626. The typical properties of this rosin are given in Table $3 .^{7}$ The rosin used in the experiments meets MIL-F-14256 specification as types $R$ and $R M A$. The solvent was removed by elevating the flux temperature to 80 to $90^{\circ} \mathrm{C}$ for 16 to 48 hours $\left(90^{\circ} \mathrm{C}\right.$ is well below the boiling point of the flux and rosin).

\section{Solvent Stabilizers}

Patents reveal that various solvent manufacturers use different stabilizers (Table 4 ). It is the purpose of stabilizers to keep the solvent from becoming acidic and from subsequent decomposition. The presence of these stabilizers would be expected to alter some of the physical properties of the solvent, especially the boiling point. The boiling point can be depressed or elevated according to Raoult's Law if the contaminant and solvent mixtures behave as ideal solutions. 
Table 1. Typical Properties of Trichloroethylene and $1,1,1-T r i c h l o r o e t h a n e$

\begin{tabular}{|c|c|c|}
\hline Properties & Tr1chloroethylere & 1,1,1-Tr1chloroethane \\
\hline Chemtcal Formula & $\mathrm{C}_{2} \mathrm{HC}^{1} \cdot 3$ & $\mathrm{C}_{2} \mathrm{H}_{3} \mathrm{Cl}_{3}$ \\
\hline Molecular Welght & 131.4 & 133.4 \\
\hline $\begin{array}{l}\text { Bo111ng Point at } \\
760 \mathrm{~mm} \mathrm{Hg}\end{array}$ & ${ }_{87} 7^{\circ} \cdot \mathrm{F}$ & $165^{\circ} \mathrm{F}^{\prime}$ \\
\hline Freezlng Point & $\begin{array}{l}-124^{\circ} \mathrm{F} \\
\quad-86.7^{\circ} \mathrm{C}\end{array}$ & $\begin{array}{l}-34^{\circ} \mathrm{F} \\
-37^{\circ} \mathrm{C}\end{array}$ \\
\hline $\begin{array}{l}\text { Specific Gravity at } \\
25 \cdot \mathrm{C}\end{array}$ & 1.456 & 1.300 to 1.32 .5 \\
\hline $\begin{array}{l}\text { Pounds per Ga1lon } \\
\text { at } 25^{\circ} \mathrm{C}\end{array}$ & 12.11 & 10.97 \\
\hline $\begin{array}{l}\text { Vapor Density } \\
\text { (air }-1.00)\end{array}$ & 4.53 & 4.55 \\
\hline $\begin{array}{l}\text { Speclfic Heat } \\
\quad\left(1 \mathrm{Btu} / 1 \mathrm{~b}^{\circ} \mathrm{F}-1 \mathrm{ca} 1 / \mathrm{g}^{\circ} \mathrm{C}\right)\end{array}$ & $0.22 \mathrm{Btu} / 1 \mathrm{~b}^{\circ} \mathrm{F}$ & $0.258 \mathrm{Btu} / 1 \mathrm{~b} \cdot \mathrm{F}$ \\
\hline $\begin{array}{l}\text { Heat of Vaporization } \\
\text { at Bo1ling Point } \\
\text { cal/g } \\
\text { Btu/1b }\end{array}$ & $\begin{array}{r}56.4 \\
101.6\end{array}$ & $\begin{array}{l}56.7 \\
102\end{array}$ \\
\hline $\begin{array}{l}\text { Solubility }(\mathrm{g} / 100 \mathrm{~g}) \text { at } \\
25^{\circ} \mathrm{C}, \mathrm{H}_{2} \mathrm{O} \text { In Solvent }\end{array}$ & 0.04 & 0.05 \\
\hline $\begin{array}{l}\text { Flash Point } \\
\text { Tag Open Cup, ASTM } \\
\text { Method D-1310 } \\
\text { Tag Closed Cup, ASTM } \\
\text { Method D-56 }\end{array}$ & $\begin{array}{l}\text { none } \\
\text { none }\end{array}$ & $\begin{array}{l}\text { none } \\
\text { none }\end{array}$ \\
\hline $\begin{array}{l}\text { Flammable Limits } \\
\text { (volume \% of solvent } \\
\text { In air) at } 25^{\circ} \mathrm{C} \\
\text { Lower Limit } \\
\text { Upper Limit }\end{array}$ & $\begin{array}{r}8.0 \\
10.0\end{array}$ & 75 \\
\hline
\end{tabular}

Gas chromatograms were made of as-received solvent, distilled solvent, and undistilled solvent (that is, solvent remaining in the flask after half of it was distilled). (See Table 5 and Figures 1 and 2.) The chromatograms identified most of the stabilizers in the solvents used in this study. Some stabilizers boiled out of solution quickly while others remained; this change in stabilizer concentration affects the boiling point of the solvent. 
Table 2. Specifications for Reagent Grade and'Technical Grade Solvent

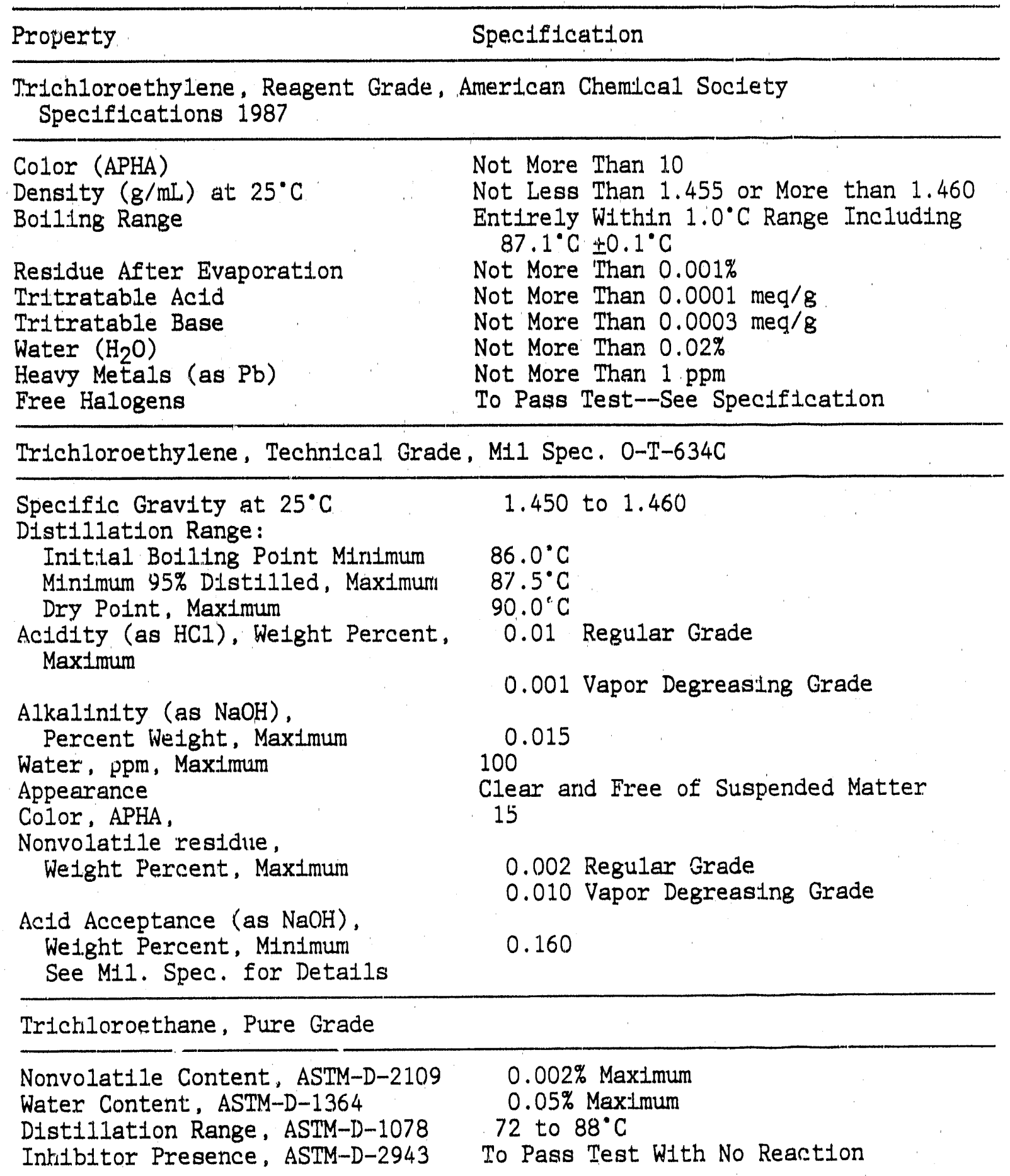


Table 2 Continued. Specifications for Reagent Grade and Technical Grade Solvent

\begin{tabular}{|c|c|}
\hline Property & Specification \\
\hline Trichloroethane, Technical Grade, & M11. Spec. 0-T-620C \\
\hline $\begin{array}{l}\text { Appearance } \\
\text { Color (Maxtmum) }\end{array}$ & $\begin{array}{l}\text { Clear and Free of Suspended Matter } \\
15 \text { Platinum Cobalt Units }\end{array}$ \\
\hline $\begin{array}{l}\text { Distillation Kange: } \\
\text { Inttial Boiling Point, } \\
\text { Minimum }\end{array}$ & $70^{\circ} \mathrm{C}$ \\
\hline $\begin{array}{l}\text { Dry Point, Maximum } \\
\text { Odor }\end{array}$ & $\begin{array}{l}88^{\circ} \mathrm{C} \\
\text { Characteristic Mild Sweet } \\
\text { No Residual Odor }\end{array}$ \\
\hline Water, ppm, Maxtmum & 100 \\
\hline $\begin{array}{l}\text { Acidity (as HC1), Weight Percent, } \\
\text { Maximum }\end{array}$ & 0.001 \\
\hline $\begin{array}{l}\text { Alkalinity (as } \mathrm{NaOH}), \text { Percent } \\
\text { Weight, Maximum }\end{array}$ & 0.015 \\
\hline $\begin{array}{l}\text { Nonvolatile Matter, Percent, } \\
\text { Maximum }\end{array}$ & 0.0101 \\
\hline Corrosion of Aluminum Alloy & $\begin{array}{l}\text { No Pitting, Etching, or } \\
\text { Discoloration }\end{array}$ \\
\hline $\begin{array}{l}\text { Specific Gravity at } 25^{\circ} \mathrm{C} \text {. } \\
\text { See M11. Spec. for Detalls. }\end{array}$ & 1.284 to 1.324 \\
\hline
\end{tabular}

Past studies at KCD have shown that stabilizers for TCE contain butylene oxide and cyclohexene oxide for vapor degreasing and solvent recycling. Cyclohexene oxide tends to stay in the sump where the stabilizer is needed the most, whereas most of the butylene oxide is easily carried over into the distillate during distillation.

\section{Specific Gravity}

Specific gravity measurements were made on TCE and TCE at various rosin-contamination levels between 0 and 50 percent by weight. The measurements were made at $25^{\circ} \mathrm{C}$ following ASTM D 2111-85, method $B$, using hydrometers $129 \mathrm{H}$ through $133 \mathrm{H}$. The data are presented in Table 6 and graphed in Figure 3. The change in specific gravity with rosin in solution fits a straight line in the 0.- to 30-percent range for TCE and TCA. Using a simple least squares fit, the equations describing this change are 
Table 3. Typical Properties of Rosin*

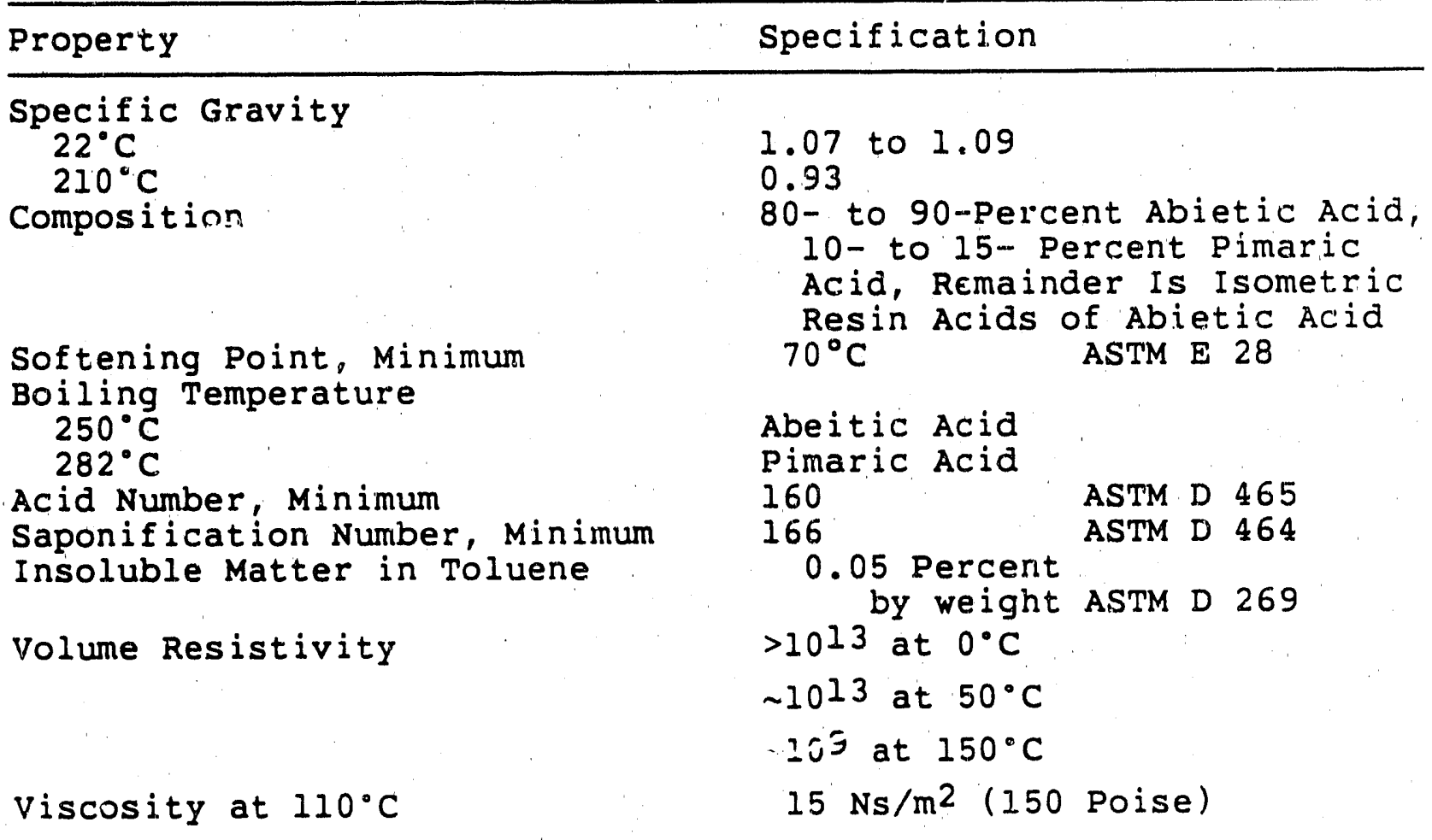

*Data from military specifications MIL-F-14256, QQS-571, $L L L-R-626$, and reference 7 .

Sg $($ solution $)=m \cdot$ wz. $+b$,

where

$m=-0.4738$ and $b=1.4505$ for $T C E$,

$m=-0.2791$ and $b=1.3124$ for $T C A$, and

Wo $(<30 \%)$ is the weight percent of rosin in the solution.

According to this least squares fit equation, the specific gravities of TCE and TCA at a zero rosin concentration are 1.4505 and 1.3124 , respectively. This is very close to the measured values of 1.4520 and 1.3130 . These clean solvent specific gravity values are within the technical grade requirements.

The ranges of specific gravity for technical grade solvents are 1.450 to 1.460 for TCE and 1.284 to 1.324 for TCA. The specific gravity could be used to measure the amount of contamination in the sump to within \pm 1.2 weight-percent of rosin contamination of TCE and within \pm 0.8 weight-percent of rosin contamination of TCA. 
Table 4. Stabilizer Packages of Trichloroethylene, $1,1,1-T r i c h l o r o e t h a n e$, and Perchloroethylene

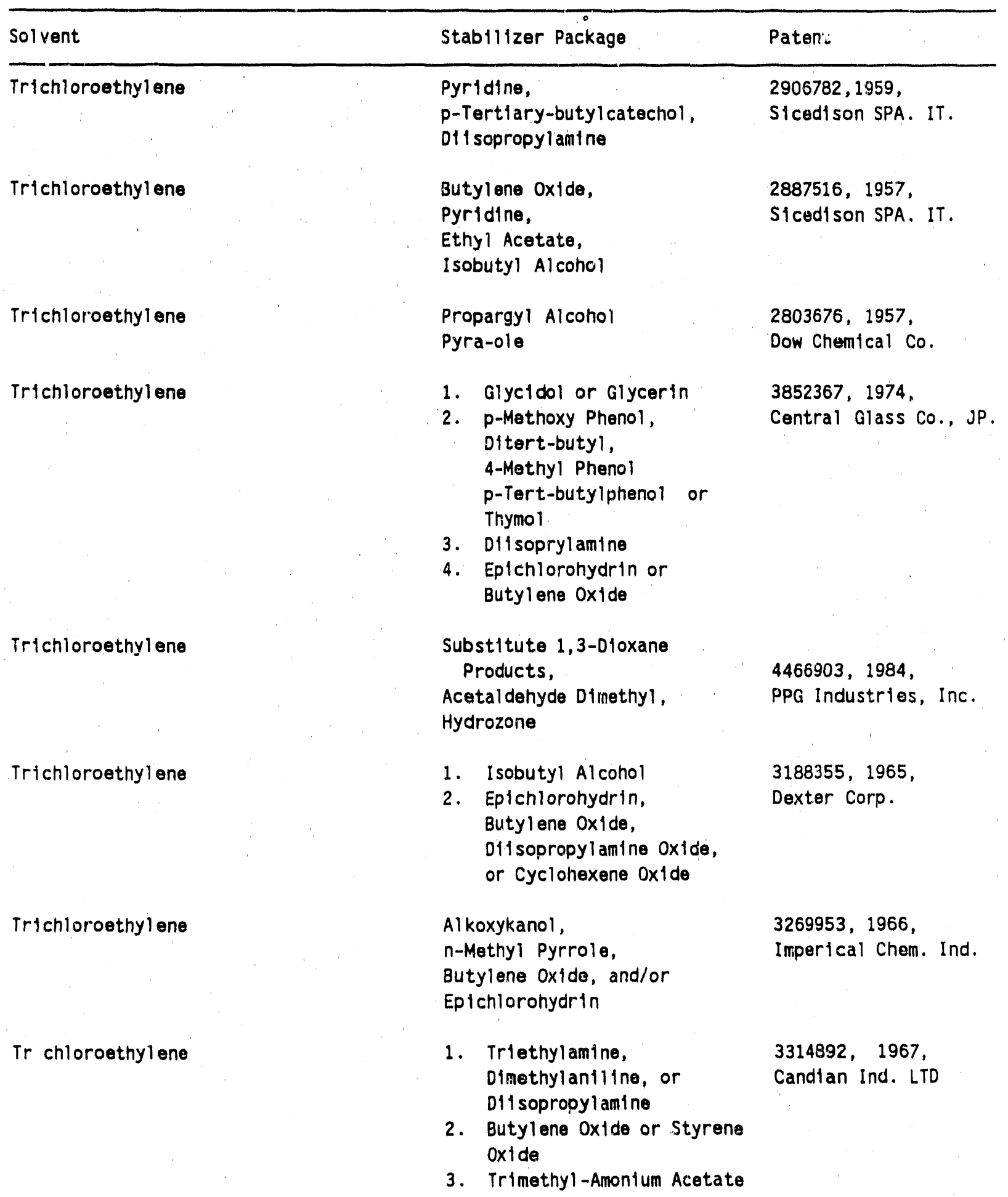


Table 4 Continued. Stabilizer Packages of Trichloroethylene, $1,1,1-$ Trichloroethane, and Perchloroethylene

\begin{tabular}{|c|c|c|}
\hline Solvent & Stabllizer Package & Patent \\
\hline Trichloroethylene & $\begin{array}{l}\text { Ethyl Acetate, } \\
\text { Acetonitrlie, or Pytazine } \\
\text { n-Methyl Pyriole }\end{array}$ & $\begin{array}{l}\text { 4368338, 1983, } \\
\text { Dow Chemical Co. }\end{array}$ \\
\hline Trichloroethylene & $\begin{array}{l}\text { 1. Cyclohexene oxide } \\
\text { 2. Butylene oxide } \\
\text { 3. n-propanol } \\
\text { and two unknown compounds }\end{array}$ & $\begin{array}{l}\text { Lab Analysis, Ref. } 39 . \\
\text { Sample from } \\
\text { PPG Industries, Inc. }\end{array}$ \\
\hline Trichloroethylene & $\begin{array}{l}\text { 1. Butylene oxide } \\
\text { 2. Epichlorohydrin } \\
\text { 3. Ethyl acetate } \\
\text { 4. n-propylamine } \\
\text { and three unknown compounds }\end{array}$ & $\begin{array}{l}\text { Lab Analyst's, Ref. } 39 . \\
\text { Sample From } \\
\text { Dow Chemical Co. }\end{array}$ \\
\hline 1,1,1-Trichloroethane & $\begin{array}{l}\text { 1,4-Dioxane, } \\
\text { Butylene Oxide, } \\
\text { 3-Butyn-1-01, } \\
\text { Ethy1, or I sopropyl Nitrate }\end{array}$ & $\begin{array}{l}4394284,1963 \\
\text { Dow Chemical Co. }\end{array}$ \\
\hline 1,1,1-Trichloroethane & $\begin{array}{l}\text { 1,4-Dioxane, } \\
\text { Nitromethane, } \\
\text { 1,2-Butylene Oxide, } \\
\text { 1,2-Epoxy Hexane }\end{array}$ & $\begin{array}{l}916129,1963 \text {, } \\
\text { Dow Chemical Co. }\end{array}$ \\
\hline 1,1,1-Trichloroethane & $\begin{array}{l}\text { 1,4-Dioxane, } \\
\text { Sec-butyl Al cohol, } \\
\text { 1,2-Butylens Oxide, } \\
\text { 1,2-Epoxy Hexane }\end{array}$ & $\begin{array}{l}916129,1963 \text {, } \\
\text { Dow Chemical Co. }\end{array}$ \\
\hline 1,1,1-Trichloroethane & $\begin{array}{l}\text { 1,4-Dioxane, } \\
\text { N1tromethane, } \\
\text { 1,2-Butylene Oxide }\end{array}$ & $\begin{array}{l}\text { Lab Analysts, Ref. } 39 . \\
\text { Sample from } \\
\text { Dow Chemical Co. } \\
\text { Like Pat.\# } 916129 .\end{array}$ \\
\hline Perchloroethylene & Tert-butyl Glycidyl Ether & $\begin{array}{l}\text { Lab Analysis, Ref. } 39 \\
\text { Sample from } \\
\text { Dow Chemical co. }\end{array}$ \\
\hline Perchloroethylene & $\begin{array}{l}\text { 1-(1-methy } 1-1 \text { - }- \text {-pyrrol-2yl })- \\
\text { Ethanone and Cyclohexene }\end{array}$ & $\begin{array}{l}\text { Lab Analysis, Rer. } 39 . \\
\text { Sample from } \\
\text { PPG Industrles, Inc. }\end{array}$ \\
\hline
\end{tabular}


Table 5. Gas Cromatographic Measurements of Solvent Stabilizers and Impurities

\begin{tabular}{|c|c|c|c|}
\hline \multirow{2}{*}{$\begin{array}{l}\text { Stabilizer, Impurities, } \\
\text { or Solvent }\end{array}$} & \multicolumn{3}{|c|}{ Percent in Solution* } \\
\hline & As-Recoived & Distilled & Undistilled \\
\hline \multicolumn{4}{|l|}{ Trichloroethylene } \\
\hline $\begin{array}{l}\text { 1. Butylene Oxide } \\
\text { 2. 1,1,1-Trichloroethane } \\
\text { 3. 1,1,2-Trichloroethane } \\
\text { 4. 1,1,2-Trichloroethylene } \\
\text { 5. Unknowns }\end{array}$ & $\begin{array}{l}0.50 \\
0.022 \\
0.099 \\
96.24 \\
3.14\end{array}$ & $\begin{array}{c}0.78 \\
0.089 \\
0.046 \\
95.41 \\
3.67\end{array}$ & $\begin{array}{l}0.22 \\
0.015 \\
0.15 \\
98.89 \\
0.72\end{array}$ \\
\hline Sum (Numbers 1-5) & 100.001 & 99.945 & 99.995 \\
\hline \multicolumn{4}{|l|}{$1,1,1$-Trichloroethane } \\
\hline $\begin{array}{l}\text { 1. Cyclohexane } \\
\text { 2. Butylene Oxide } \\
\text { 3. 1,3-Dioxolane } \\
\text { 4. 1,1,2-Trichloroethylene } \\
\text { 5. Secondary Butanol }\end{array}$ & $\begin{array}{l}0.0049 \\
0.32 \\
0.84 \\
0.0087 \\
0.97\end{array}$ & $\begin{array}{l}0.0088 \\
0.38 \\
0.95 \\
0.0074 \\
1.12\end{array}$ & $\begin{array}{l}0.0046 \\
0.25 \\
0.75 \\
0.013 \\
0.80\end{array}$ \\
\hline $\begin{array}{l}\text { 6. 1,4-Dioxane } \\
\text { 7. 1,2-Dichloroethane } \\
\text { 8. Nitramethane } \\
\text { 9. Nitroethane } \\
\text { 10. 1,1,1-Trichloroethane }\end{array}$ & $\begin{array}{l}0.91 \\
0.12 \\
0.57 \\
0.0047 \\
96 . ? 5\end{array}$ & $\begin{array}{l}0.32 \\
0.11 \\
0.77 \\
0.0027 \\
96.34\end{array}$ & $\begin{array}{l}1.50 \\
0.13 \\
0.34 \\
0.0063 \\
96.21\end{array}$ \\
\hline Sum (Numbers 1-10) & 99.9983 & 100.0089 & 100.0039 \\
\hline
\end{tabular}

The rosin contamination level could be determined to within a 0.5 -percent accuracy if the clean solvent specific gravity is known. Other contaminants in the sump can affect the accuracy of rosin weight estimation, but specific gravity measurements should still provide a good estimate of the rosin contamination level.

The change in specific gravity of a pure substance with temperature can be calculated by using the following equation:

$\mathrm{Sg}(t)=a\left(t-25^{\circ} \mathrm{C}\right)+\mathrm{Sg}\left(25^{\circ} \mathrm{C}\right)$,

where $a$ is the thermal coefficient of density.' Pure TCE and TCA have a thermal coefficient of density of 0.001649 and 0.001657 , respectively. The thermal coefficient of density of 


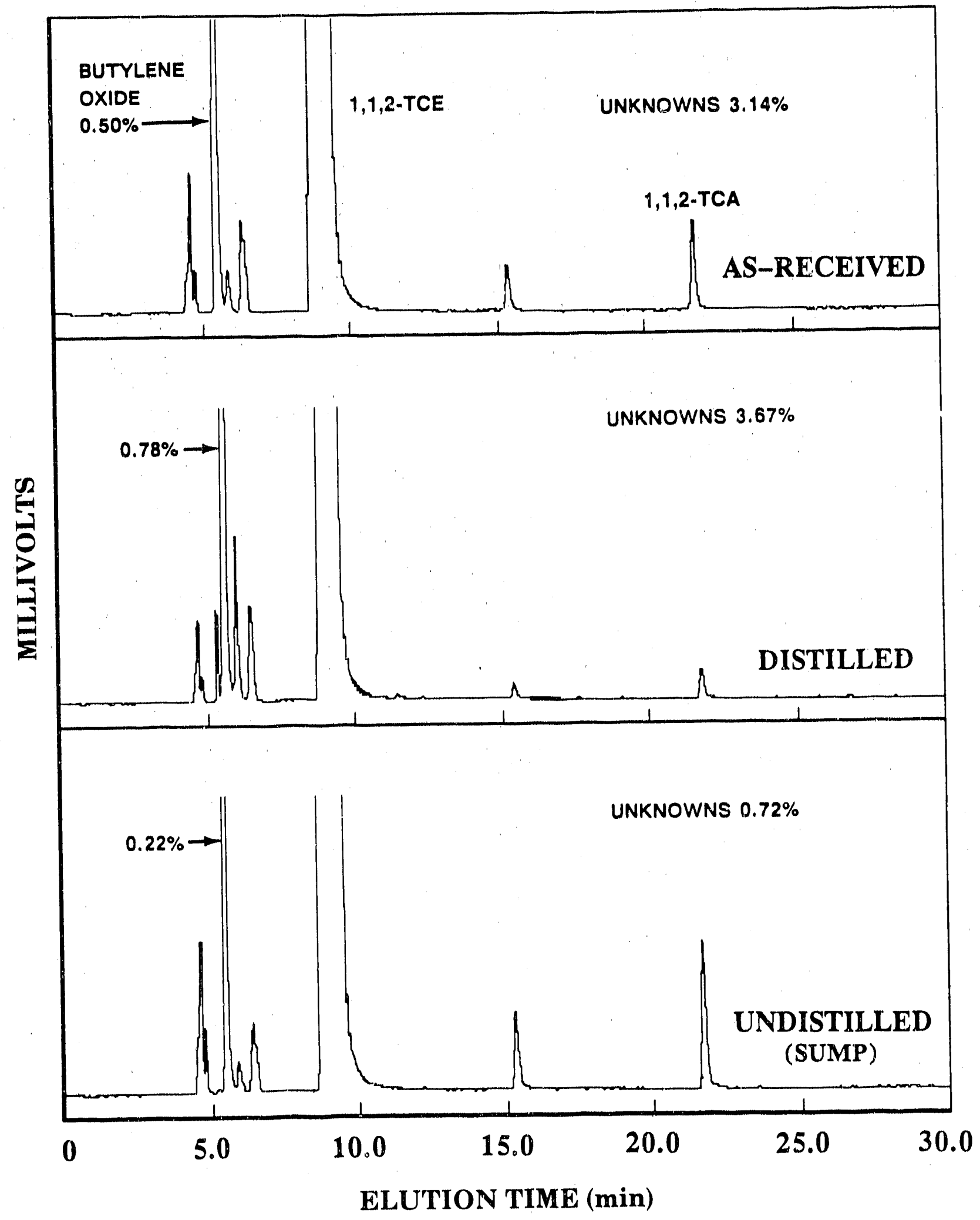

Figure 1. Gas Chromatogram of Trichloroethylene As-Received, Distilled, and Undistilled 


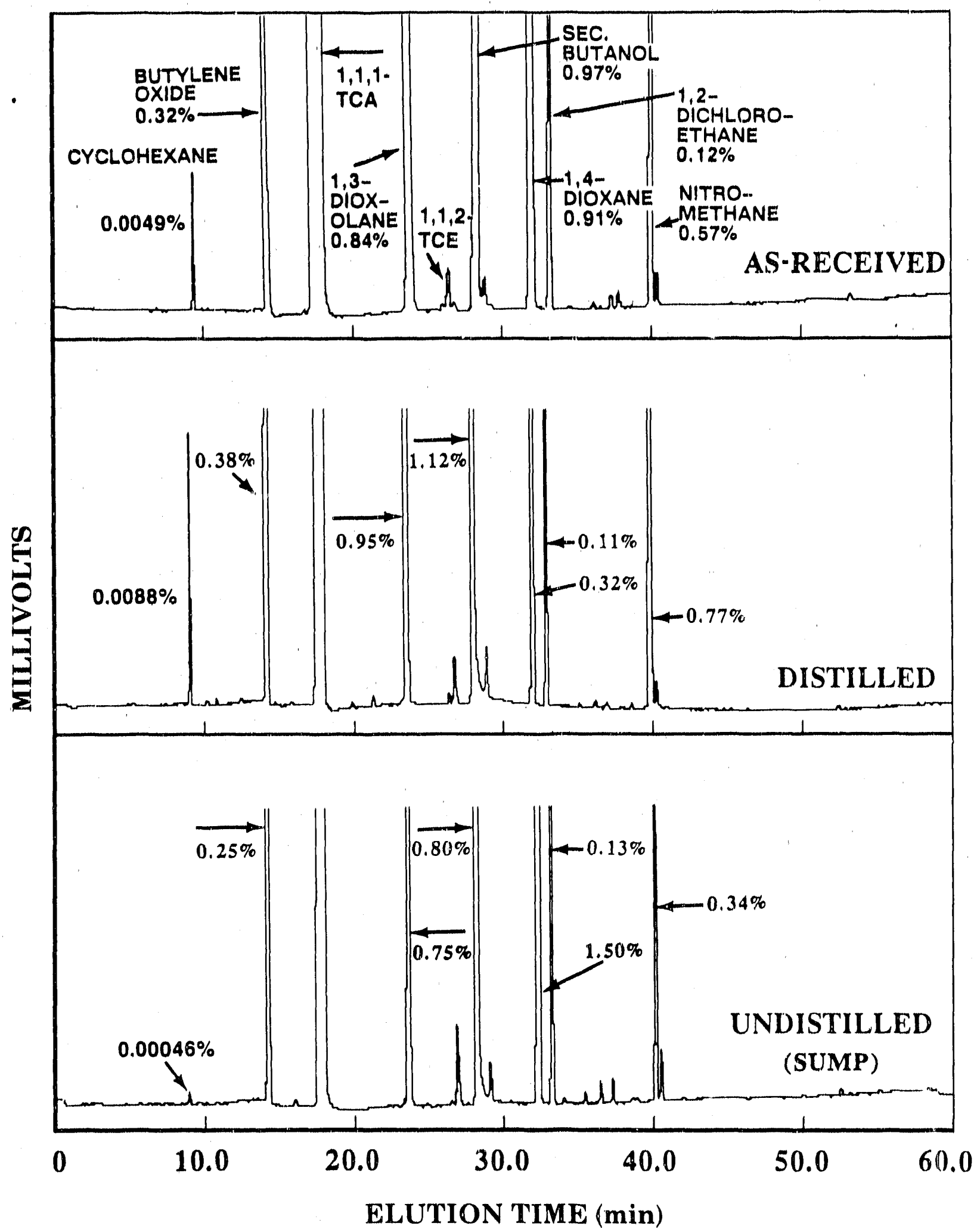

Figure 2. Gas Chromatogram of 1,1,1-Trichloroethane As-Received, Distilled, and Undistilied 
Table 6. Specific Gravity and volume Change of TCE and TCA at Various Contamination Levels by Rosin at $25^{\circ} \mathrm{C}$

\begin{tabular}{|c|c|c|c|c|c|c|}
\hline \multirow[b]{2}{*}{$\begin{array}{l}\text { Rosin } \\
\text { Coritamiriation } \\
\text { Leve1 (percent } \\
\text { by welght) }\end{array}$} & \multicolumn{3}{|l|}{ TCE } & \multicolumn{3}{|l|}{ TCA } \\
\hline & $\begin{array}{l}\text { Speciftc } \\
\text { Gravity }\end{array}$ & $\begin{array}{l}\text { Rosin* } \\
\text { Source }\end{array}$ & $\begin{array}{l}\text { Volume } \\
\text { Change } \\
\text { (percent) }\end{array}$ & $\begin{array}{l}\text { Speciflc } \\
\text { Gravity }\end{array}$ & $\begin{array}{l}\text { Rosint } \\
\text { Source }\end{array}$ & $\begin{array}{l}\text { Volume } \\
\text { Change } \\
\text { (percent) }\end{array}$ \\
\hline $\begin{array}{r}0 * * \\
5.0 \\
10.0 \\
15.0 \\
20.0\end{array}$ & $\begin{array}{l}1.452 .0 \text { \# } \\
1.4245 \\
1.4012 \\
1.3772 \\
1.3519\end{array}$ & $\begin{array}{l}-- \\
197 \\
197 \\
197 \\
197\end{array}$ & $\begin{array}{c}0 \\
7.30 \\
15.14 \\
24.04 \\
34.26\end{array}$ & $\begin{array}{l}1.3130 \text { 非 } \\
1.2973 \\
1.2825 \\
1.2686 \\
1.2602\end{array}$ & $\begin{array}{l}- \\
A \\
A \\
A \\
A\end{array}$ & $\begin{array}{c}0 \\
6.54 \\
13.75 \\
21.76 \\
30.24\end{array}$ \\
\hline $\begin{array}{l}25.0 \\
30.0 \\
30.0 \\
40.0 \\
50.0\end{array}$ & $\begin{array}{l}1.3298 \\
1.3101 \\
1.3132 \\
1.2663 \\
1.2437\end{array}$ & $\begin{array}{r}1544 \\
1544 \\
197 \\
1544 \\
197\end{array}$ & $\begin{array}{l}45.59 \\
58.33 \\
57.96 \\
91.11 \\
133.5\end{array}$ & $\begin{array}{l}1.2408 \\
1.2274 \\
1.2309 \\
1.2042 \\
1.2036\end{array}$ & $\begin{array}{l}\text { B } \\
B \\
A \\
B \\
A\end{array}$ & $\begin{array}{c}41.09 \\
52.82 \\
52.39 \\
81.73 \\
118.2\end{array}$ \\
\hline
\end{tabular}

*This column indicates the flux from which the rosin was obtained. The alcohol carrier solvent was removed by evaporation at 80 to $90^{\circ} \mathrm{C}$.

**Indilcates as-recelved technical grade solvent.

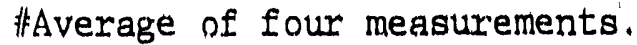

非Average of six measurements.

The percent of volume change values were calculated from the measured changes in specific gravity by the following equat: Ion which is derlved in the text.

$\%$ Volume Change $-\left[\frac{1}{1-W \%}\right]\left[\frac{S_{g}(O \%)}{S g(W \%)}\right]-1$

rosin is -0.000798 based on the two data points from Table 3 . A rigorous equation relating the individual coefficient densities to that of a mixture was not found. Comparison of the coefficients suggests that the coefficient for a solution would be less than that of pure solvent for TCE or TCA.

\section{Volume Change}

The change in volume with percent-by-weight contamination can be calculated from the specific gravity measurements. The initial volume of the solvent, $v i$, is given by

$V i=\frac{S w}{S g(0 q)}$, 


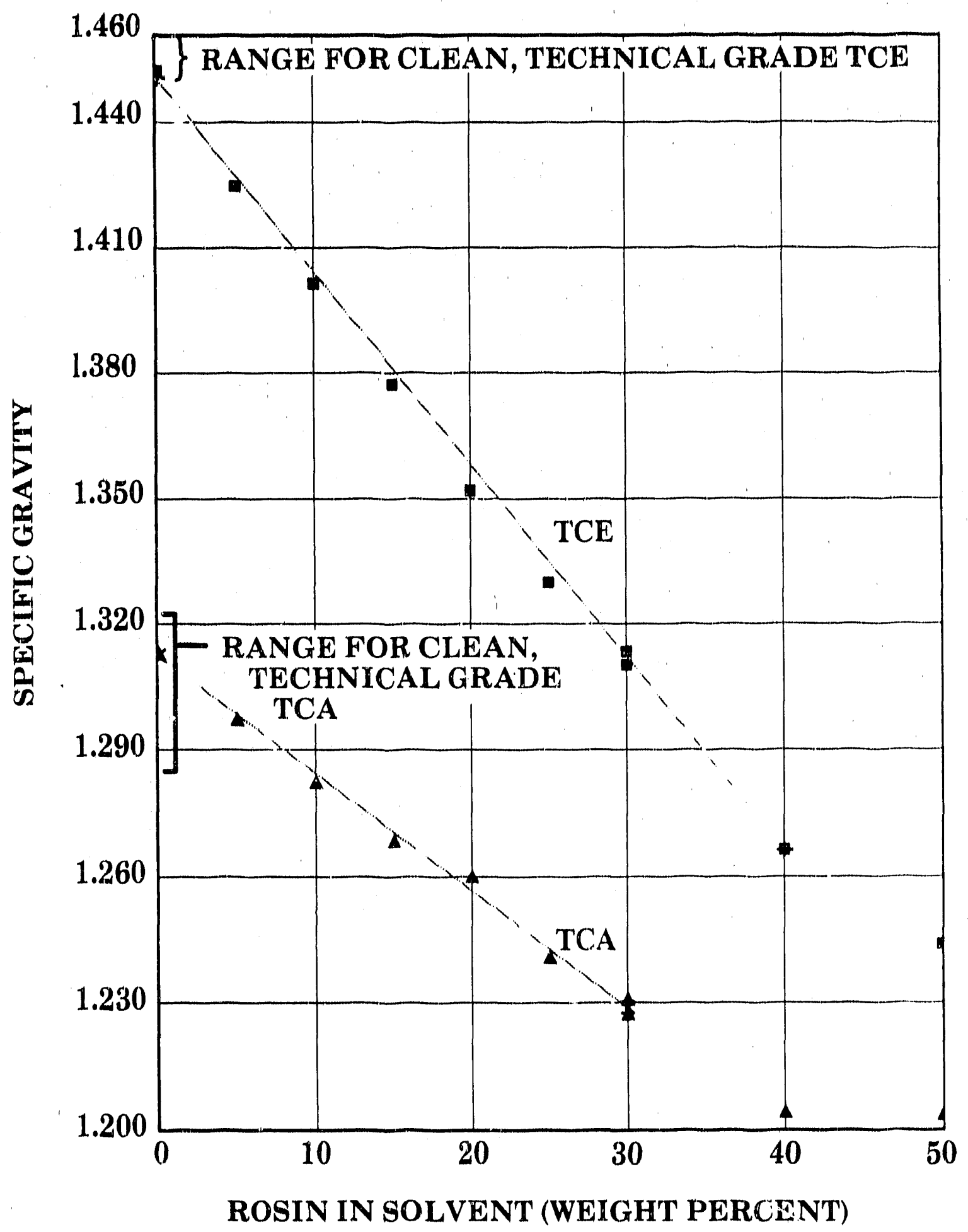

Figure 3. Specific Gravity Versus Rosin Contamination Levels for I'richloroethylene and 1,1,1-Trichloroethane at $25^{\circ} \mathrm{C}$ 
where Sw is the weight of the pure solvent and $\mathrm{Sg}(0 q)$ is the specific gravity of the solvent with 0 percent, by $w$ ight, contamination. The volume at some contamination level $\mathrm{W} \%$ is given by

$v(W z)=\frac{[S w+R w]}{S g(w z)}$,

where Rw is the weight of the rosin in solution. The contamination level Wo is given by

$\mathrm{W} z=\frac{\mathrm{RW}}{[\mathrm{SW}+\mathrm{RW}]}$.

The percent volume caused by a contamination of the solvent by rosin is then given by

$$
\begin{aligned}
\operatorname{dV}(W q) & =\frac{[V(W q)-V i]}{V i} \\
& =\left[\frac{[S w+R w]}{S g(W q)}-\frac{S w}{S g(O q)}\right] \frac{S g(0 z)}{S w} \\
& =\left[\frac{1}{I-W q}\right]\left[\frac{S g(0 q)}{S g(W q)}\right]-1 .
\end{aligned}
$$

This equation is as accurate as the equation modeling the specific gravity, which is a function of weight percent. The results of these calculations are given in Table 6 and graphed in Figure 4 .

\section{Dielectric Constant}

The dielectric constant, $K$, of a material is a measure of the way in which a medium responds to an electric field. It is easiest to think of the dielectric constant in terms of the capacitance increase caused by filling a parallel plate capacitor with a material of dielectric constant $K$. The capacitance of a parallel plate capacitor is given by

$C=\frac{K \in A}{d}$,

where $e$ is the permittivity of free space, $A$ is the area of the plates, $d$ is the distance between plates, and fringe effects are neglected. 


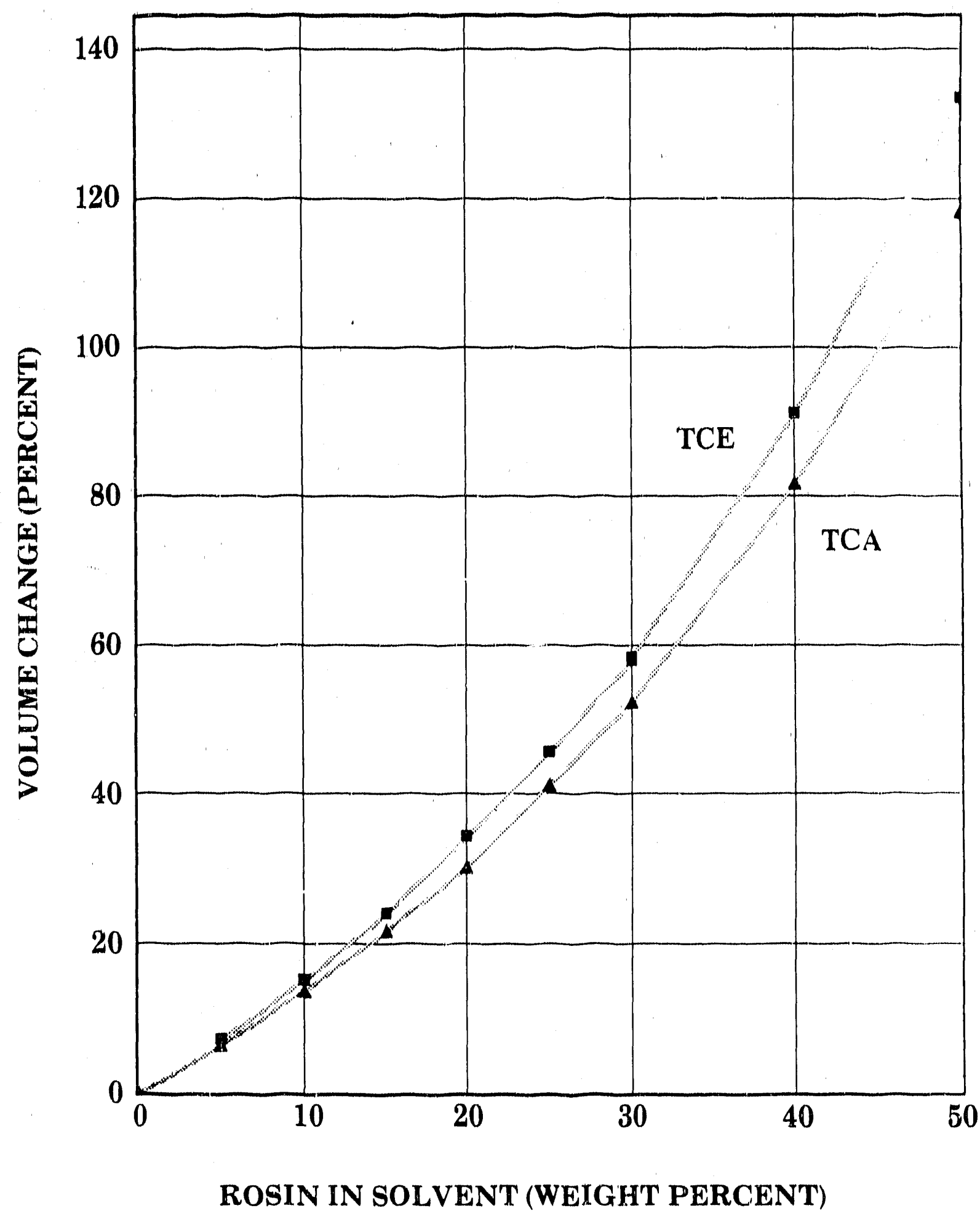

Figure 4. Volume Change Versus Rosin Contamination Levels for Trichloroethylene and $1,1,1-\operatorname{Tr} i c h l o r o e t h a n e$ at $25^{\circ} \mathrm{C}$ 
The dielectric constants of contaminated solutions were measured by using a guarded-ring parallel-plate capacitor and making capacitance measuremerits. Capacitance measurements were made using a capacitance test cell and an automatic capacitance bridge. The test cell had a micrometer adjustment with 0.001 -inch markings for the parallel plate spacing and had a guard ring to eliminate fringe effects. The parallel plate was 2.0 inches in diameter with a 0.2 -inch-wide circumferential guard ring. The capacitance bridge was accurate to \pm 1 percent for the capacitance values measured. All measurements were made at room temperature. Capacitance measurements were made at $10 \mathrm{kHz}$, $100 \mathrm{kHz}$, and $1 \mathrm{MHz}$, with a few measurements at $1 \mathrm{kHz}$. Capacitance measurements were made at spacings of $0.050,0.100$, $0.150,0.200$, and 0.250 inch between the parallel plates. The measurements can be found in Appendix $A$ of this report. The dielectric constant. was calculated by using the equation

$\mathrm{K}=\frac{\mathrm{C}_{\mathrm{e}}}{\mathrm{Ca}}$,

where $C e$ is capacitance of the test cell filled with the solution and $\mathrm{Ca}$ is the capacitance of the test cell filled only with air. The results of the calculations are summarized in Table 7 and graphed in Figure 5.

The dielectric constant of reagent grade TCA is 6.44 , about 0.7 below the measured dielectric value of technical grade TCA. The dielectric constant of reagent grade TCE is 4.42 , very close to the measured dielectric value of technical grade TCE. The difference in the values of TCA may be caused by the stabilizers in I'CA and the impurities in the technical grade solvent.

Measurements at $1 \mathrm{MHz}$ and the 0.050 -inch spacing were slightly higher than other measurements and were not included in the averages presented in Table 7 . The dielectric constant measurements at any rosin contamination level of TCE or TCA were essentially constant from $1 \mathrm{kHz}$ to $1 \mathrm{MHz}$ for all spacings of the parallel plates. The dielectric constant measurements for TCA were constant from $1 \mathrm{kHz}$ to $100 \mathrm{kHz}$ but increased slightly at $1 \mathrm{MHz}$ for all plate spacings. The difference in the solution's dielectric constant between using rosin from the two fluxes was less than 2 percent (see the 30-percent by weight contamination level data in Table 7).

The change in dielectric constant of TCE and TCA is not significant enough to provide an accurate determination of the rosin concentration in solvent for small changes in containination level. It is remarkable how consistent the dielectric constant of TCE remained over the large range of rosin contamination levels, This consistency could be used to quickly and inexpensively distinguish between contaminated solutions of TCE 
Table 7. Dielectric Constant of Rosin-Contaminated Solvents

\begin{tabular}{|c|c|c|c|c|}
\hline \multirow{3}{*}{$\begin{array}{l}\text { Contamlnation } \\
\text { Level As-Recelved } \\
\text { (percent by welght) }\end{array}$} & \multicolumn{4}{|c|}{ Dielectric Constant (Average of Measured Values) } \\
\hline & \multicolumn{2}{|l|}{ TCE } & \multicolumn{2}{|l|}{ TCA } \\
\hline & $1 \mathrm{kHz}$ to $100 \mathrm{kHz}$ & $1 \mathrm{MHz}$ & $1 \mathrm{kHz}$ to $100 \mathrm{kHz}$ & $1 \mathrm{MHz}$ \\
\hline $\begin{array}{l}0.00 \text { (a) } \\
0.00 \text { (b) } \\
0.05 \\
0.1 \\
0.5\end{array}$ & $\begin{array}{l}3.4684 \\
3.4950 \\
3.4682 \\
3.4690 \\
3.4731\end{array}$ & $\begin{array}{l}3.4755 \\
3.5012 \\
3.4749 \\
3.4768 \\
3.4805\end{array}$ & $\begin{array}{l}7.1840 \\
7.2203 \\
7.2127 \\
7.2182 \\
7.1946\end{array}$ & $\begin{array}{l}7.2374 \\
7.2699 \\
7.2634 \\
7.2686 \\
7.2434\end{array}$ \\
\hline $\begin{array}{l}1.0 \\
3.0 \\
5.0 \\
10 \\
15\end{array}$ & $\begin{array}{l}3.4735 \\
3.4861 \\
3.4969 \\
3.5290 \\
3.5484\end{array}$ & $\begin{array}{l}3.4816 \\
3.4930 \\
3.5049 \\
3.5358 \\
3.5549\end{array}$ & $\begin{array}{l}7.1676 \\
7.0559 \\
6.8940 \\
6.6728 \\
6.4213\end{array}$ & $\begin{array}{l}7.2034 \\
7.1075 \\
6.9407 \\
6.7160 \\
6.4586\end{array}$ \\
\hline $\begin{array}{l}20 \\
2.5 * \\
30 \star \\
30 \\
40 \star\end{array}$ & $\begin{array}{l}3.5926 \\
3.6134 \\
3.6259 \\
3.5810 \\
3.6396\end{array}$ & $\begin{array}{l}3.5998 \\
3.6175 \\
3.6281 \\
3.5876 \\
3.6395\end{array}$ & $\begin{array}{l}6.3555 \\
6.0561 \\
5.8508 \\
5.7741 \\
5.5325\end{array}$ & $\begin{array}{l}6.3860 \\
6.0815 \\
5.8795 \\
5.8002 \\
5.5183\end{array}$ \\
\hline $50 \star$ & 3.6126 & 3.6138 & 4.7426 & 4.6570 \\
\hline
\end{tabular}

(a) Solution measured on October $11,1988$.

(b) Solution measured on November 5, 1988; same lot and container as in (a). The capacitance measuring bridge was recalibrated between the two measurements; this may account for the difference in measured values of Identical solutions.

* Solutions with asterisk were contaminated with rosin from Flux B. A11 other solutions were contaminated with rosin from Flux A.

and TCA. The usual method of distinguishing contaminated TCE and TCA solutions requires time-consuming laboratory analysis.

\section{Dissipation Factor}

Dissipation factor is a measure of the power loss when a material is used as a dielectric in a capacitor. The losses are caused by microscopic mechanical effects resulting from the forces caused by the varying electrical field and from resistive losses in the dielectric. The dissipation factor, sometimes called the loss tangent, is defined as the ratio of the real impedance divided by the complex impedance of the dielectric.'.

The dissipation factor was measured using the same equipment and procedure as was used for measuring the dielectric constant. The data are in Appendix $B$ and are presented graphically in Figure 6 . 


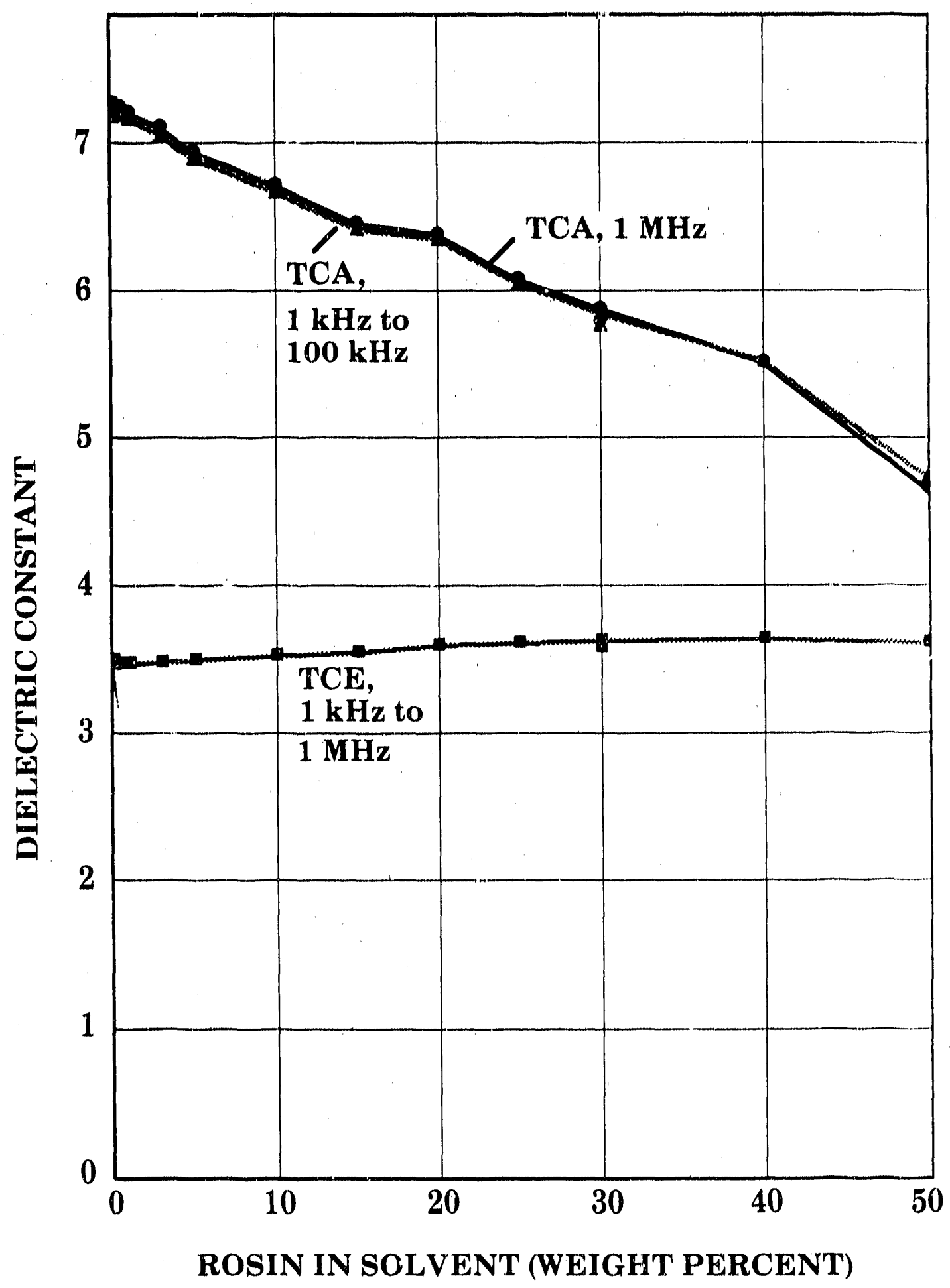

Figure 5. Dielectric Constant Versus Rosin Contamination Levels for Trichloroethylene and 1,1,1-Trichloroethane at $25^{\circ} \mathrm{C}$ 
The dissipation factor of pure and contaminated TCE and TCA varied inversely proportional to frequency. At any frequency, the dissipation factor did change significantly in the 0 - to 5 -percent by weight concentration level of rosin (see Figure 6). These data show that by measuring the dissipation factor one may monitor the very low level concentration of rosin in TCA. Unfortunately, the rapid change in dissipation factor for TCE does not occur until. after the 3-percent contamination level is reached. Combined measurement of the dissipation factor and dielectric constant may be the easiest and quickest way to monitor the contamination level at various concentration levels.

\section{Boiling Point}

For the purposes of this discussion, the boiling point is the measured temperature of the vapor zone as stated in ASTM D 1078-86, "Distillation Range of Volatile Organic Liquids," or it can be the measured temperature in the vapor zone (or in the solution) for some other described laboratory setup. According to the technical grade specifications (Table 2), the solvent boiling point for TCE must be $86^{\circ} \mathrm{C}$ minimum $\left(186.8^{\circ} \mathrm{F}\right)$, and for TCA, the boiling point must be $70^{\circ} \mathrm{C}$ minimum $\left(158^{\circ} \mathrm{F}\right)$. There is no specification upper limit on the initial boiling temperature of technical grade TCE or TCA, but there is a distillation range specified and it will be used to specify the boiling point limits.

The boiling point of any solvent would be expected to change with contamination according to Raoult's law for ideal solutions and with deviations from Raoult's law for nonideal solutions. In an ideal. solution, the intermolecular attractions between solvert molecules and solute molecules are the same as the intermolecular attractions between molecules of pure solute or pure solvent. ${ }^{21}$ only by experimental methods can one readily determine if some contamination will interact with the solvent as an ideal solution and how the boiling point will be altered by that contamination.

\section{Boiling Point, Oil Contamination}

A brochure on vapor degreasing by Dow Chemical gives boiling points of oil-contaminated solvents in a 0 - to 80-percent by weight contamination level. The graphs and data were apparently based on an earlier published paper which was a theoretical analysis and were not based on actual measurements.22 The oils considered in the theoretical analysis were a mineral lard oil, a sulfochlorinated-lard oil, and a sulfurized-lard oil. The theoretical data from 0 - to 30 -percent contamination are given in Table 8 and Figures 7 and 8 .

The assumption made in the theoretical model is that the mixtures of solvent and oils behave as ideal solutions. If this assumption for oils and solvents is erroneous, all the 


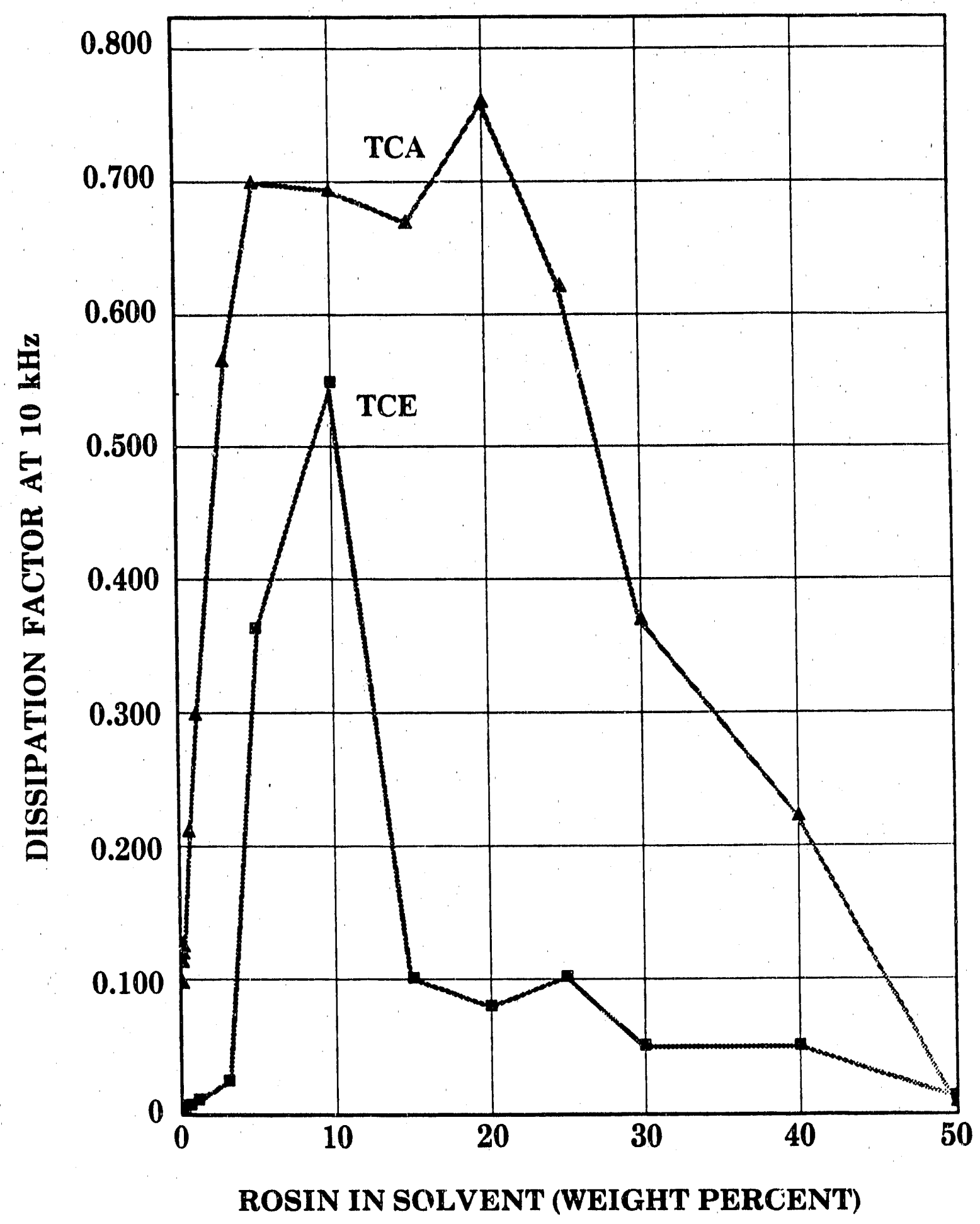

Figure 6. Dissipation Factor Versus Rosin Contamination Levels for Trichloroethylene and 1,1,1-Trichloroethane 
Table 8. Theoretical Boiling Temperature for 5- to 30-Percent Oil-Contamination Levels of Trichloroethylene and $1,1,1-\operatorname{Tr}$ ichloroethane

\begin{tabular}{|c|c|c|c|c|}
\hline \multirow[b]{2}{*}{ Solvent } & \multirow{2}{*}{$\begin{array}{l}\text { Contamination } \\
\text { (percent } \\
\text { by volume) }\end{array}$} & \multicolumn{3}{|c|}{$\begin{array}{l}\text { Calculated Boiling } \\
\text { Point }\left({ }^{\circ} \mathrm{C}\right) *\end{array}$} \\
\hline & & Oil A & Oil B & Oil C \\
\hline Trichloroethylene & $\begin{array}{r}5 \\
10 \\
15 \\
20 \\
30\end{array}$ & $\begin{array}{l}87.4 \\
87.9 \\
88.5 \\
89.1 \\
90.6\end{array}$ & $\begin{array}{l}87.4 \\
88.0 \\
88.6 \\
89.3 \\
90.9\end{array}$ & $\begin{array}{l}87.3 \\
87.8 \\
88.3 \\
88.9 \\
90.2\end{array}$ \\
\hline $1,1,1$-Trichloroethane & $\begin{array}{r}5 \\
10 \\
15 \\
20 \\
30\end{array}$ & $\begin{array}{l}75.3 \\
75.9 \\
76.6 \\
77.3 \\
79.0\end{array}$ & $\begin{array}{l}75.4 \\
76.0 \\
76.7 \\
77.4 \\
79.2\end{array}$ & $\begin{array}{l}75.3 \\
75.8 \\
76.4 \\
77.1 \\
78.6\end{array}$ \\
\hline
\end{tabular}

*Contaminants :

Oil $A$ is a mineral-lard oil.

Oil $B$ is a sulfochlorinated-lard oil.

Oil $C$ is a sulfurized $\pi$ neral oil.

conclusions are invalid. In addition, the theoretical analysis did not include the effects of the solvent stabilizers on the boiling point temperature.

Boiling Point, Stabilizers in Solution

Solvent stabilizers are expected to affect the boiling point of a solvent. During distillation, the concentration of stabilizer components in the solvent would change unless the mixture is a true azeotrope. Boiling point temperature measurements were made of the solution according to ASTM D 1078. ASTM D 1078 requires that the measuring thermometer be in the vapor zone above the boiling solution and not in the solution. The data can be found in Appendix $B$ and are graphed in Figures 9 and 10. The approximately $1^{\circ} \mathrm{C}$ difference in temperature measurements between the $100-\mathrm{mL}$ and $250-\mathrm{mL}$ solutions is attributed to the change in height of the thermometer above the boiling solvent.

Boiling Point, Rosin Contamination

The electronic assembly manufacturing departments at KCD would have solder flux, not oil, as the major contaminant in a 


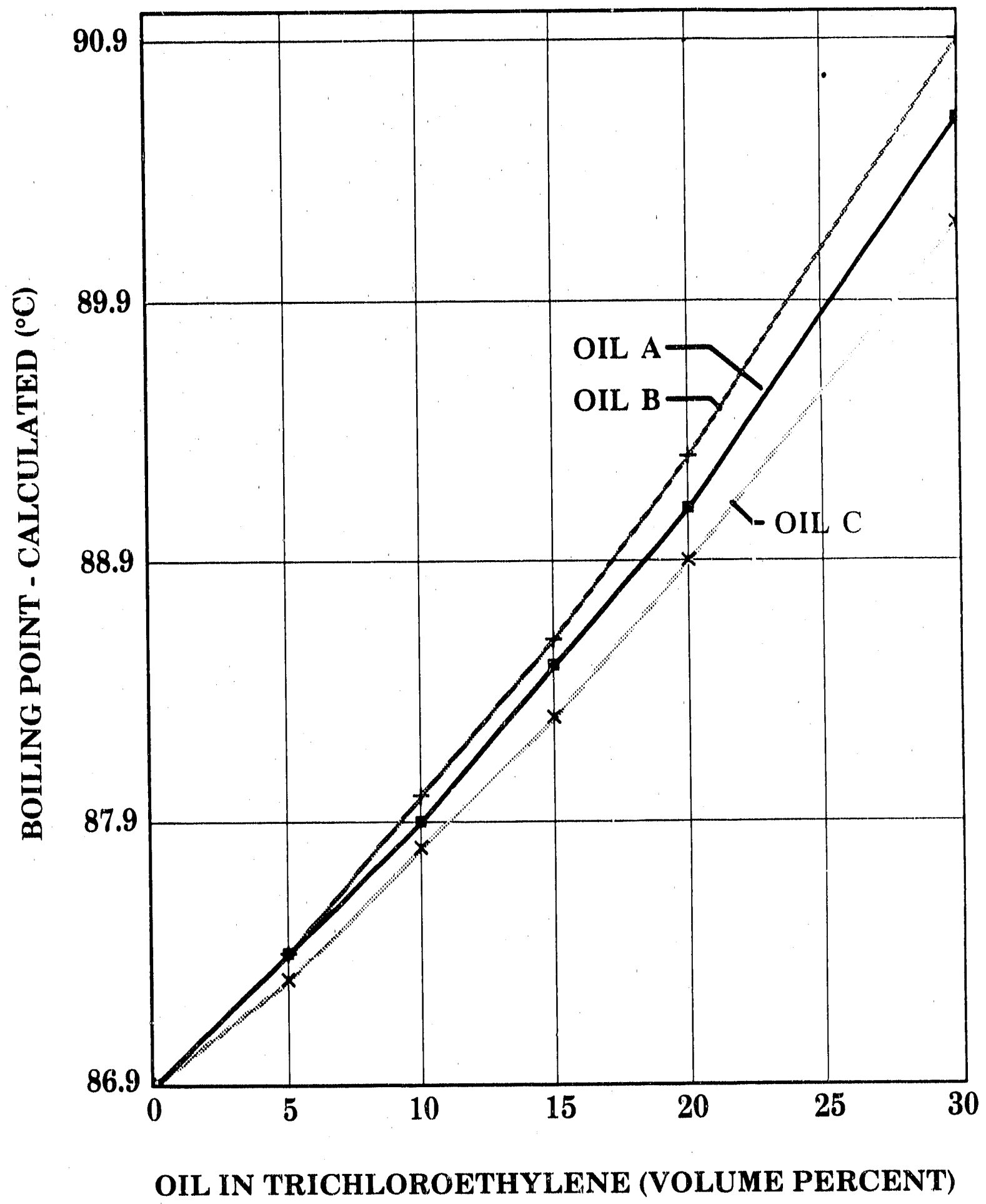

Figure 7. Theoretical Boiling Point Versus Oil Contamination Levels for Trichloroethylene 


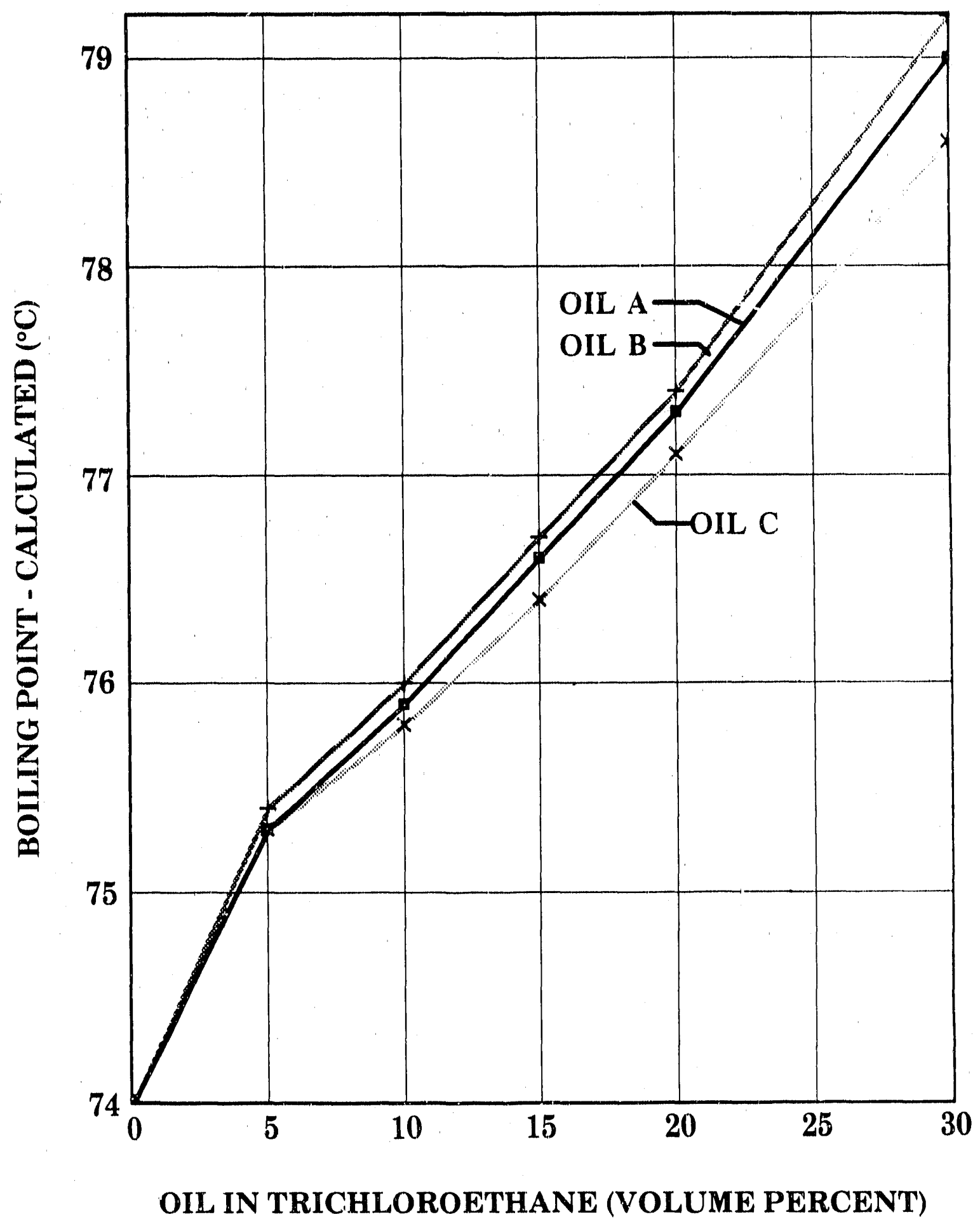

Figure 8. Theoretical Boiling Point Versus oil Contamination Levels for 1,1,1-Trichloroethane 


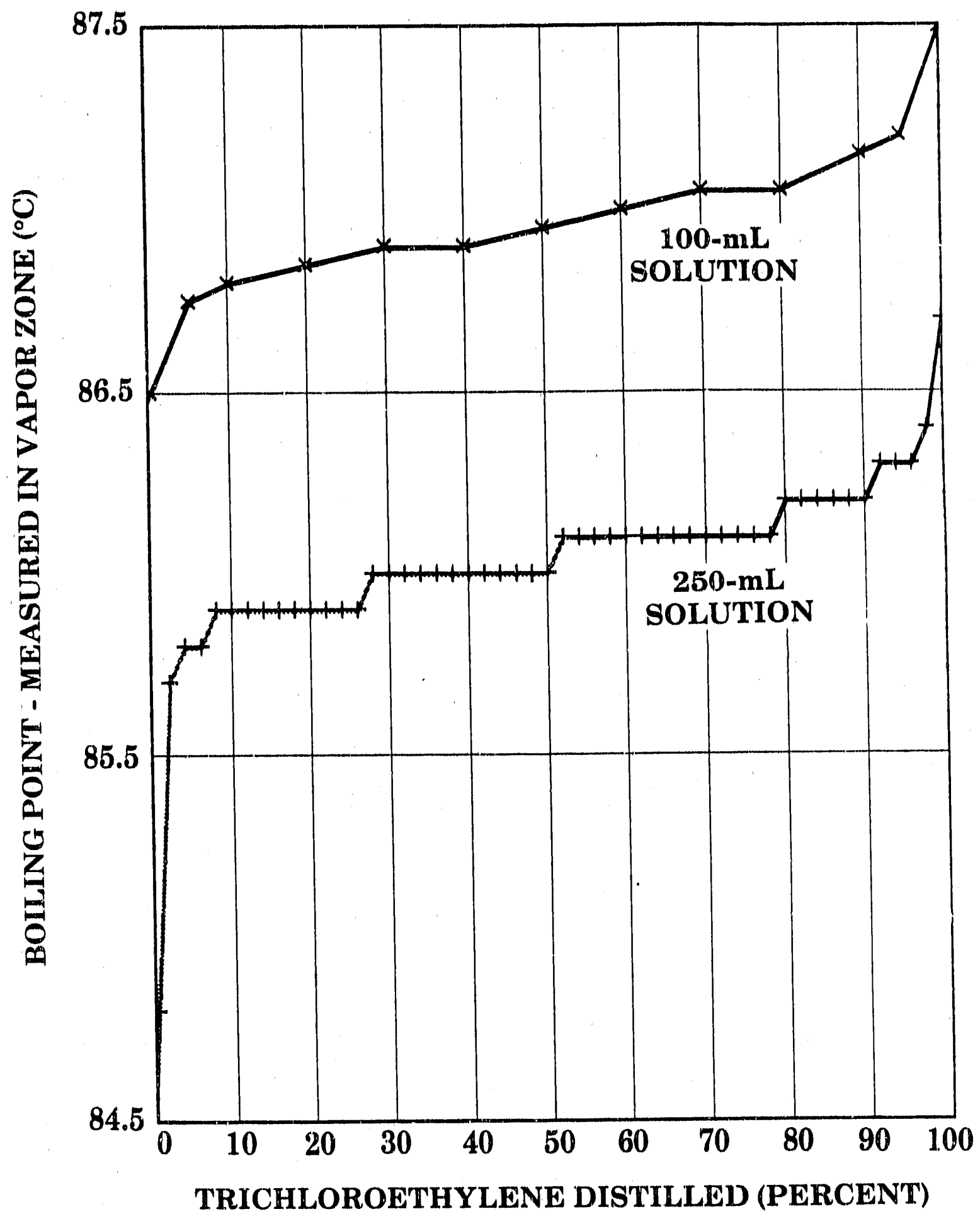
Figure 9. Boiling Point Change During Distillation of
As-Received Trichloroethylene 


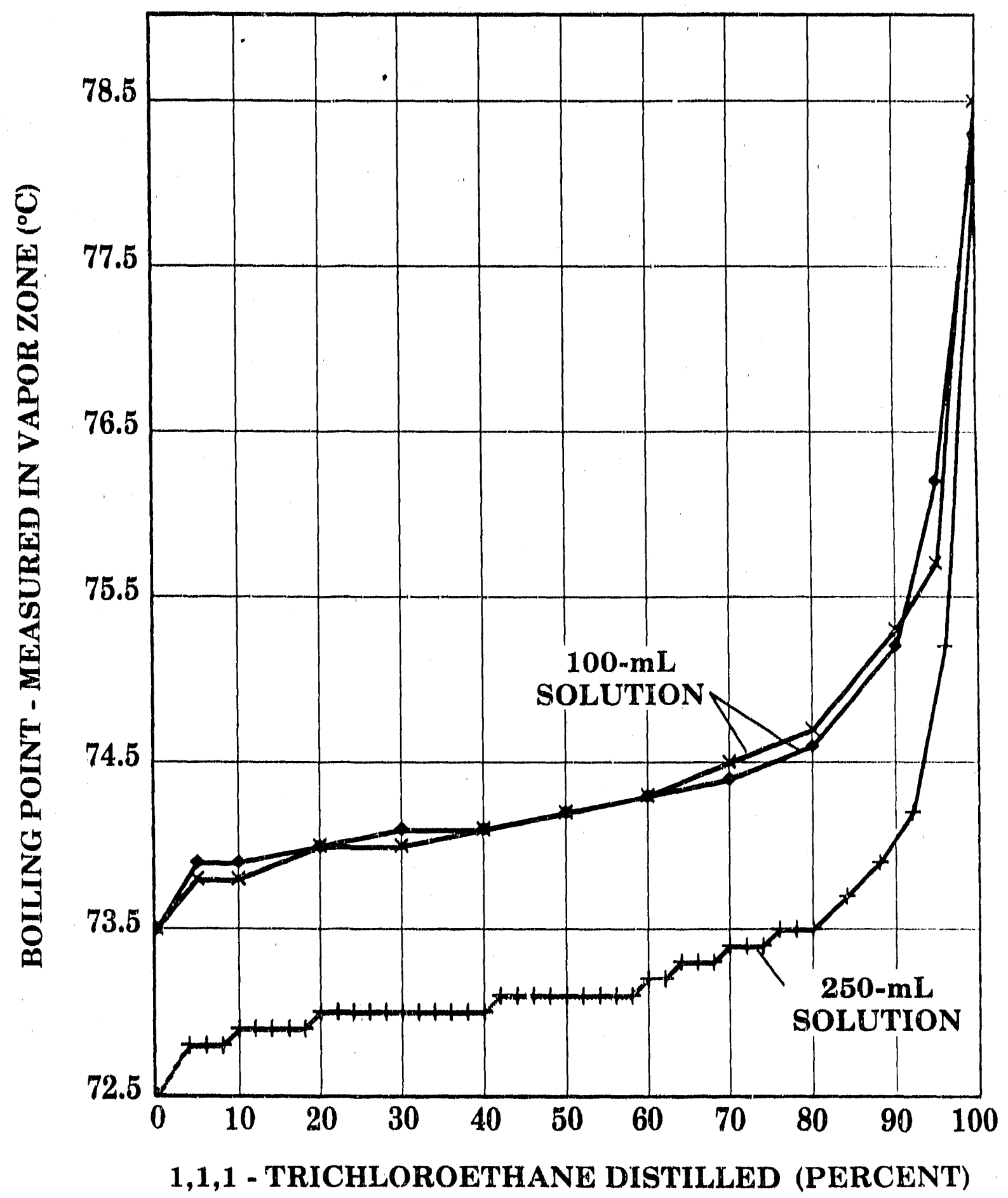

Figue 10. Boiling Point Change During Distillation of As-Received 1,1,1-Trichloroethane 
distillation sump. This would be typical for most electronic cleaning applications at KCD. Flux is mainiy rosin ( 80 to $90 \%$ abeitic acid, with 10 to $15 \%$ pimaric acid) diluted with alcohol. ${ }^{13}$ The boiling points of these acids are 250 and $282^{\circ} \mathrm{C}$, respectively, which is much higher than either solvent; consequently," the rosin may be considered as a nonvolatile solute.

Two soldering fluxes were the sources of rosin for the boiling point contamination studies. The flux was placed in an oven at 80 to $90^{\circ} \mathrm{C}$ for 16 to 48 hours to drive of isopropyl alcohol, which was the solvent carrier. Solder flux $A$ is 36 -percent rosin by weight, and solder flux B is purchased at KCD under a specification requiring flux with 50 -percent rosin by weight.

Solder fluxes also contain activators to aid in the removal of oxides from metal surfaces. The type of activator, amount of activator, and equivalent chlorine ion content of flux activators for many fluxes can be found in a report on solder fluxes and perhaps in flux material safety data sheets. For flux $A$, the activator is triethanolamine hydrochloride, and for $f$ lux $B$, the activator is dimethylamine hydrochloride. The activators produce an equivalent chlorine content in these fluxes at 0.03 and 0.16 percent by weight of the rosin for fluxes and $B$, respectively.

In preparation of the contaminated solutions, rosin was observed to dissolve easily in TCE and TCA at rosin weight levels of 20 percent and less. The rosin dissolved more quickly in TCE than TCA at all contamination levels. At higher levels, the solutions had to set overnight, and at the 40 - and 50 -percent levels, the solution had to be hedted to get all the rosin to dissolve. once the rosin dissolved, the rosin did not readily come out of solution at 40 -percent and lower concentration levels. At the 50-percent level, there was a small amount of thick syrup-like residue on the glass walls after cooling to room temperature.

Initial efforts to measure the boiling point of rosincontaminated solutions followed the ASTM D 1078 procedure, which measures the temperature in the solvent vapors above the boiling solution. This method gave inconsistent results. The ASTM D 1078 procedure is designed for measuring the boiling points of pure chemicals and has severe limitations if applied to contaminated solutions.

The vapor pressure of a solution with nonvolatile and nonideal solute as the contamination varies according to how many solvent molecules per unit volume are in solution. This is because the bolling temperature and vapor pressure of the solvent in a 
solution is altered by the molar fraction of the solute in solution. The greater the quantity of nonvolatile solute, the lower the molar fraction and the lower the vapor pressure at a given temperature. To reach a bolling point, the temperature of the solution must increase to the point where the vapor pressure of the diluted solution equals the atmospheric pressure. To measure the bolling point of contaminated solutions, the temperature probe must be in the solution, not above it as is the common laboratory practice for pure chemicals.

Rosin is a nonvolatile contarnination that is a nonideal solute in TCE and TCA. A modified ASTM method (F'igure 11) was used to measure the boiling points of the contaminated solutions. As the solvent is distilled, the contamination level of the solution increases. The contamination level at any point can be calculated from the known amount of rosin in solution, the initial amourit of solvent in the flask, and the amount of solvent distilied. The solution volume was $500 \mathrm{~mL}$ initialiy. The temperature was measured with a thermocouple in the solution as the solvent was being distilled. The thermocouple was $120 \mathrm{~mm}$ lower than the mercury thermometer and at about the $50 \mathrm{~mL}$ of solution level. The temperature measurements are given in Appendix $B$ and are graphed in Figures 12 and 13 . Only the initial concentration and twice initial concentration temperature measurements are graphed in Figures 12 and 13 .

In all tests, the boiling point of as-recelved material started lower than the bolling point of pure solvent. This was caused by the presence of stabilizers in the solution, which also did not behave as true azeotropes. Some stabilizers bolled out of solution quickly while others remained. This is evident from the gas chromatograms (see Figures 1 and 2 and Table 5). These stabilizers were the main influence altering the solvent boiling point if the rosin-contamination level was at less than 30 -percent by weight. Above 35-percent by weight rosin contamination, the bolling point was significantly affected by the rosin in solution. Based on these data, the temperature of the boiling solution could be used to determine the rosin contamination level in the 35- to 50-percent by weight contamination range; corrections for atmospheric pressure changes would need to be made to any temperature measurement.

Boiling Point, Atmospheric Effects

The boiling point of any solution is directly related to the vapor pressure of the solution and the atmospheric pressure. As the atmospheric pressure changes, the boiling point will also change. The change in boiling point, dT, caused by a change in atmospheric pressure from standard pressure $(760 \mathrm{~mm} \mathrm{Hg})$, is given by the equation

$d T=L(273.3+T)(760-P)$, 


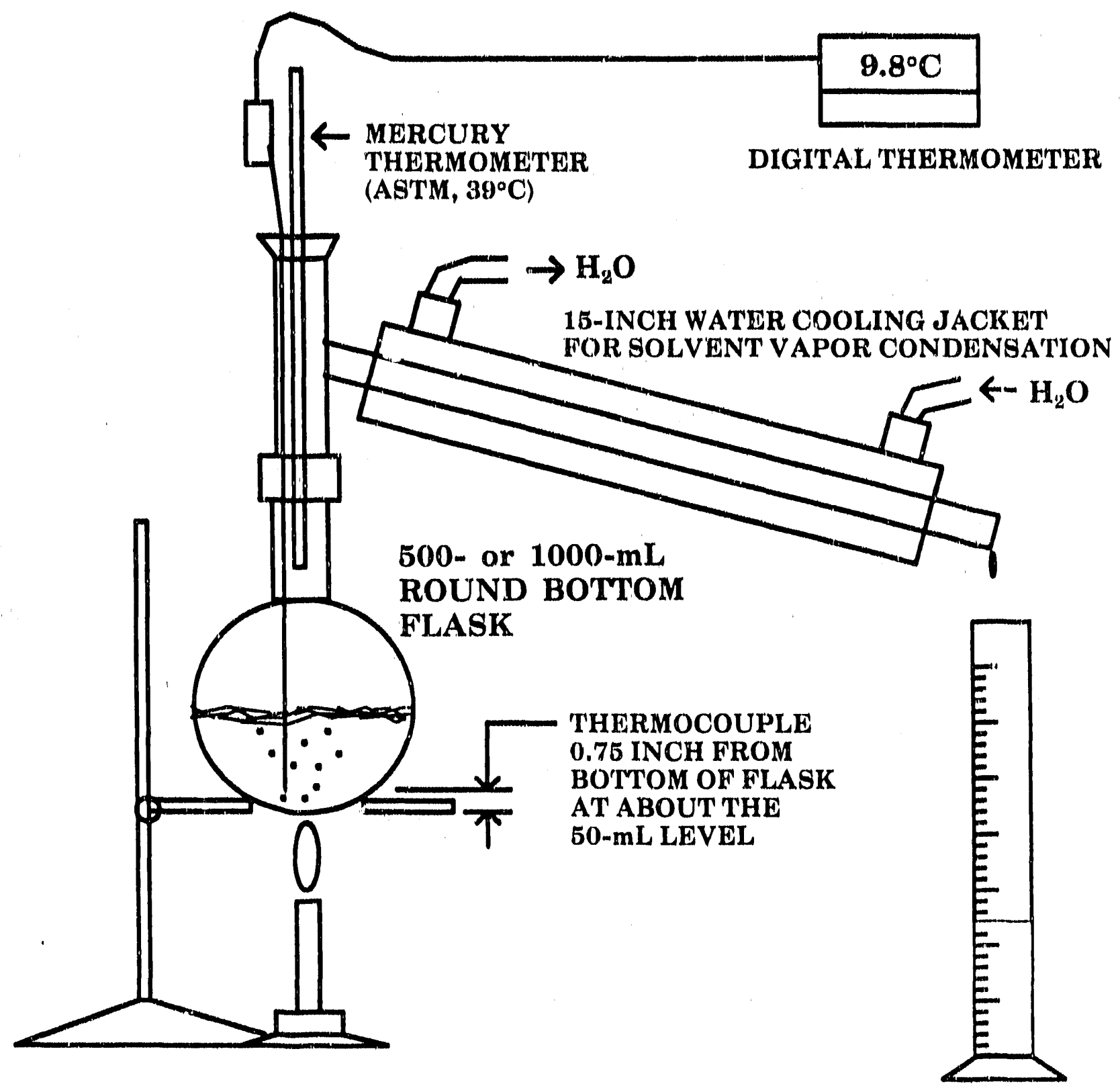

Figure 11. Laboratory Apparatus for Boiling Point Measurements of Contaminated Solutions

where $L$ is the gas constant for the solvent (about 0.00012 ), $T$ is the observed boiling point in degrees Celsius, and $P$ is the atmospheric pressure in $\mathrm{mm} \mathrm{Hg}$ at which $\mathrm{T}$ was measured.' The change in boiling point with pressure is sometimes more simply given as 


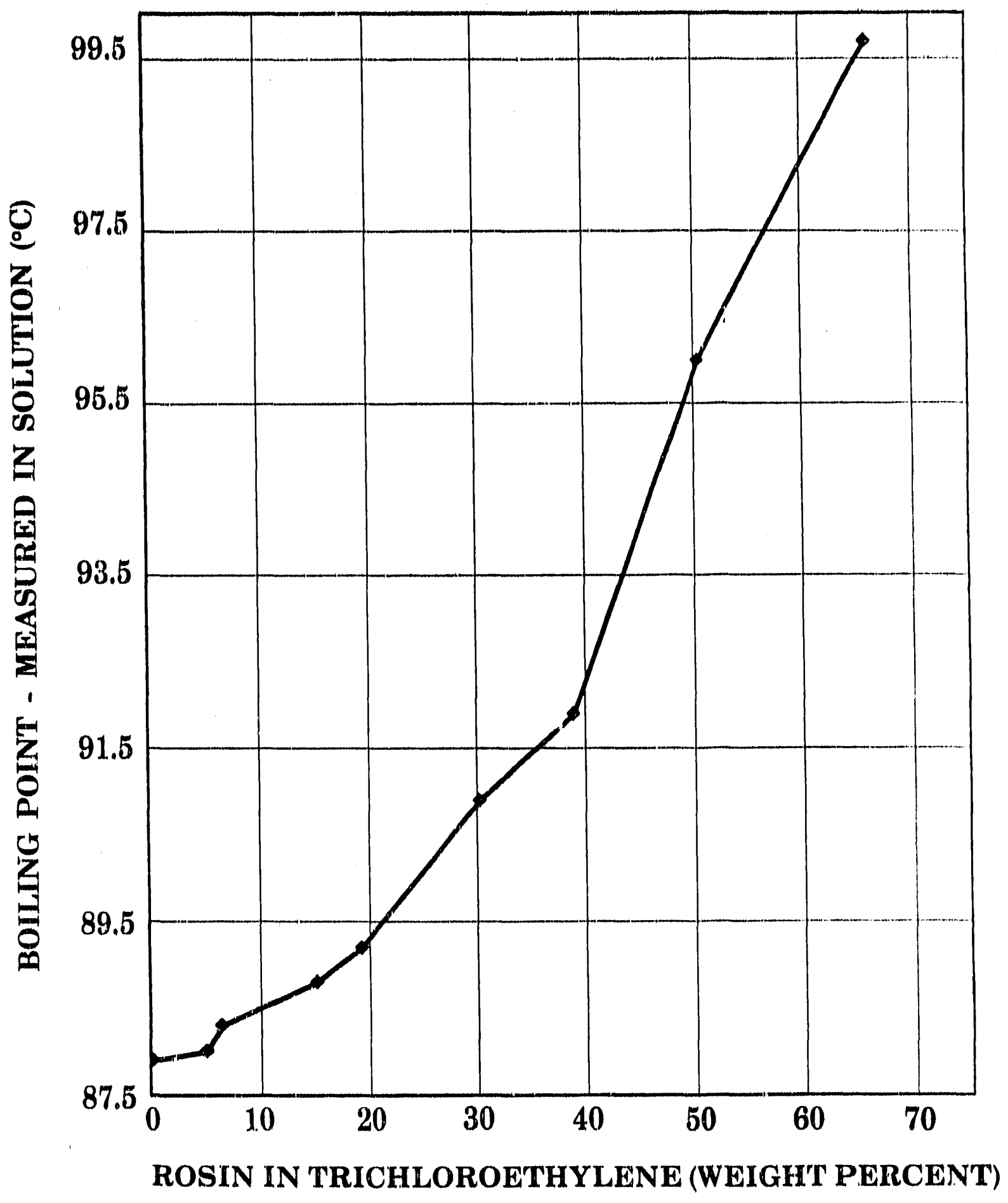

Figure 12. Boiling Point Versus Rosin Contamination Levels for Trichloroethylene 


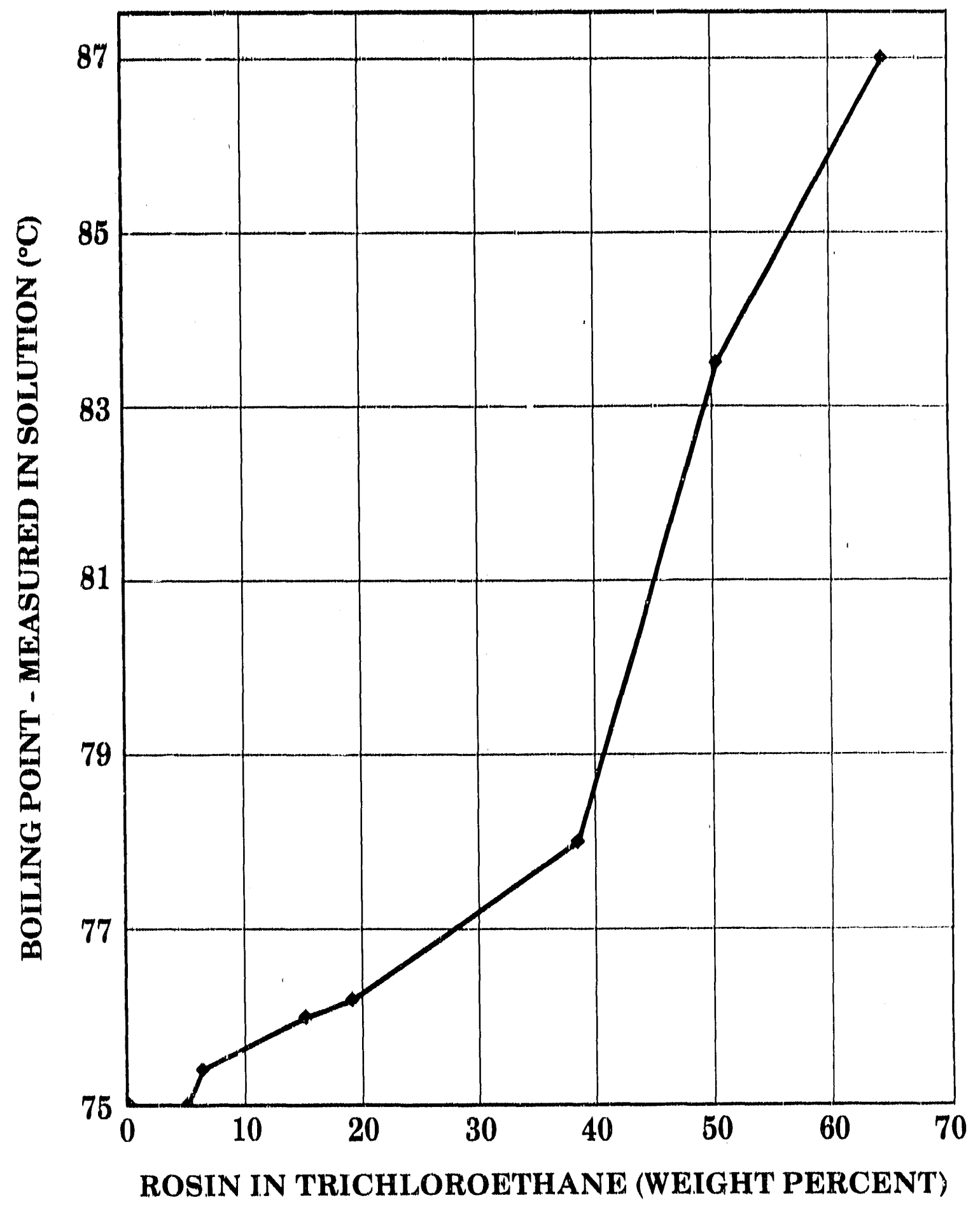

Figure 13. Boiling Point Versus Rosin Contamination Levels for 1,1,1-Trichloroethane 
where $Z$ is 0.044 for TCE and 0.043 for TCA.' Based on these equations, one would expect daily pressure variations to cause a \pm 0.3 to $0.6^{\circ} \mathrm{C}$ varlation in the boliling point. The bolling point data in the Appendices have been corrected for atmospheric pressure change and normalized to $760 \mathrm{~mm} \mathrm{H}$.

\section{Nonvelatile Residue}

Laboratory experiments measured the amount of nonvolatile residue carried over in the distillation of various rosin contamination levels of TCE and TCA. The laboratory apparatus was arranged as illustrated in Figure 11. A 500-mL measure of contaminated solution was placed in the bolling flask, and another $50-\mathrm{mL}$ measure of as-received solvent was added to the flask. The solution was distilled at a slow rate (as recommended in ASTM D 1078) until $100 \mathrm{~mL}$ of solvent were collected. An additional $100 \mathrm{~mL}$ of as-received solvent were added and the process was repeated. Maintaining the total amount of solvent in the flask at $500 \pm 50 \mathrm{~mL}$ kept the percent by weight of contamination within about 10 percent of the original value. A total of $200 \mathrm{~mL}$, minimum, of distliled solvent was collected for nonvolatile residue carryover measurements.

The 200-mL or greater solutions were evaporated and weighed. The procedure followed was generally in conformance with

ASTM D 2109-85, "Nonvolatile Matter in Halogenated Organic

Solvents and Their Mixtures," except for the quantity of solution used. The amounts carried over in the laboratory distillation process were very small and always within technical grade specifications (see Table 9 and Figure 14). The as-received TCE and I'CA had nonvolatile contents of 0.0138 and 0.00178 percent by weight, respectively; these values are above the specification limits as given in Table 2 .

Contaminated solvents were also collected from sumps of vapor degreasers and waste collection cans from spray booths at KCD. These solvents were contaminated from 0.3 to 14 percent, by weight, with various unknown oils, rosins, and other substances. A solution volume of $500 \mathrm{~mL}$ was placed in the boiling flask, and $250 \mathrm{~mL}$ of solvent were distilled for nonvolatile residue measurements. Distiliing $250 \mathrm{~mL}$ of solution, without adding solution, increased the final contamination level to approximately twice the initial value. The results of the nonvolatile weight measurements are given in Table 10 and illustrated in Figure 15. The carryover of nonvolatile residue in each case was less than 0.001 percent by welght. The distillation process adequately separates the solvent from the contamination. 
Table 9. Nonvolatile Carryover During Distillation of Contaminated Trichloroethylene and 1,1,1-Trichloroethane

\begin{tabular}{|c|c|c|c|c|c|}
\hline \multirow[b]{2}{*}{$\begin{array}{l}\text { Rosin } \\
\text { Contamination } \\
\text { Level In Distilled } \\
\text { Solution (percent by } \\
\text { welght) }\end{array}$} & \multicolumn{2}{|l|}{ TCE } & \multicolumn{2}{|l|}{ TCA } & \multirow[b]{2}{*}{$\begin{array}{l}\text { Rosin } \\
\text { Source }\end{array}$} \\
\hline & $\begin{array}{l}\text { Nonvolatile } \\
\text { Residue } \\
\text { (percent } \\
\text { by welght) }\end{array}$ & $\begin{array}{l}\text { Evaporated } \\
\text { Solution } \\
\text { size } \\
\text { (grams) }\end{array}$ & $\begin{array}{l}\text { Nonvolatile } \\
\text { Residue } \\
\text { (percent } \\
\text { by wolght) }\end{array}$ & $\begin{array}{l}\text { Elaporated } \\
\text { Solution } \\
\text { S1ze } \\
\text { (grams) }\end{array}$ & \\
\hline As-Recelved & 0.0138 & 038.73 & 0.00177 & 242.08 & nono \\
\hline As-Recelved DIsttlled & 0.00004 & 287.66 & 0.00001 & 127.60 & none \\
\hline 5 & 0.00004 & 286.75 & 0.00008 & 259.22 & A \\
\hline 15 & 0.00014 & 286.50 & 0.00012 & 260.96 & A \\
\hline 30 & 0.00052 & 286.73 & 0.00042 & 259.94 & A \\
\hline 50 & 0.00052 & 286.20 & 0.00023 & 257.95 & A \\
\hline
\end{tabular}

\section{Vapor Pressure}

The quantity of solvent in the air is limited by the maximum amount of solvent that can remain in a vapor form at the air temperature. The maximum amount of solvent vapor in air is determined by the ideal gas law and the vapor pressure of the gas at that temperature. The ideal gas law applied to partial pressures is

$P=\frac{n R T(k)}{v}$,

where $P$ is partial pressure caused by the gas, $n$ is the number of moles of the gas sample, $R$ is the universal gas constant, $T(k)$ is the temperature in kelvins, and $V$ is volume. The solvent in weight per volume, $D$, is given by

$$
\begin{aligned}
D & =\frac{m n}{V} \\
& =\frac{m P(T)}{[R T]},
\end{aligned}
$$

where $m$ is the mole weight of the solvent and $P(T)$ is the vapor pressure as a function of the temperature. $P(T)$ has been experimentally determined and can be given in graph form or by Antoine's equation. 


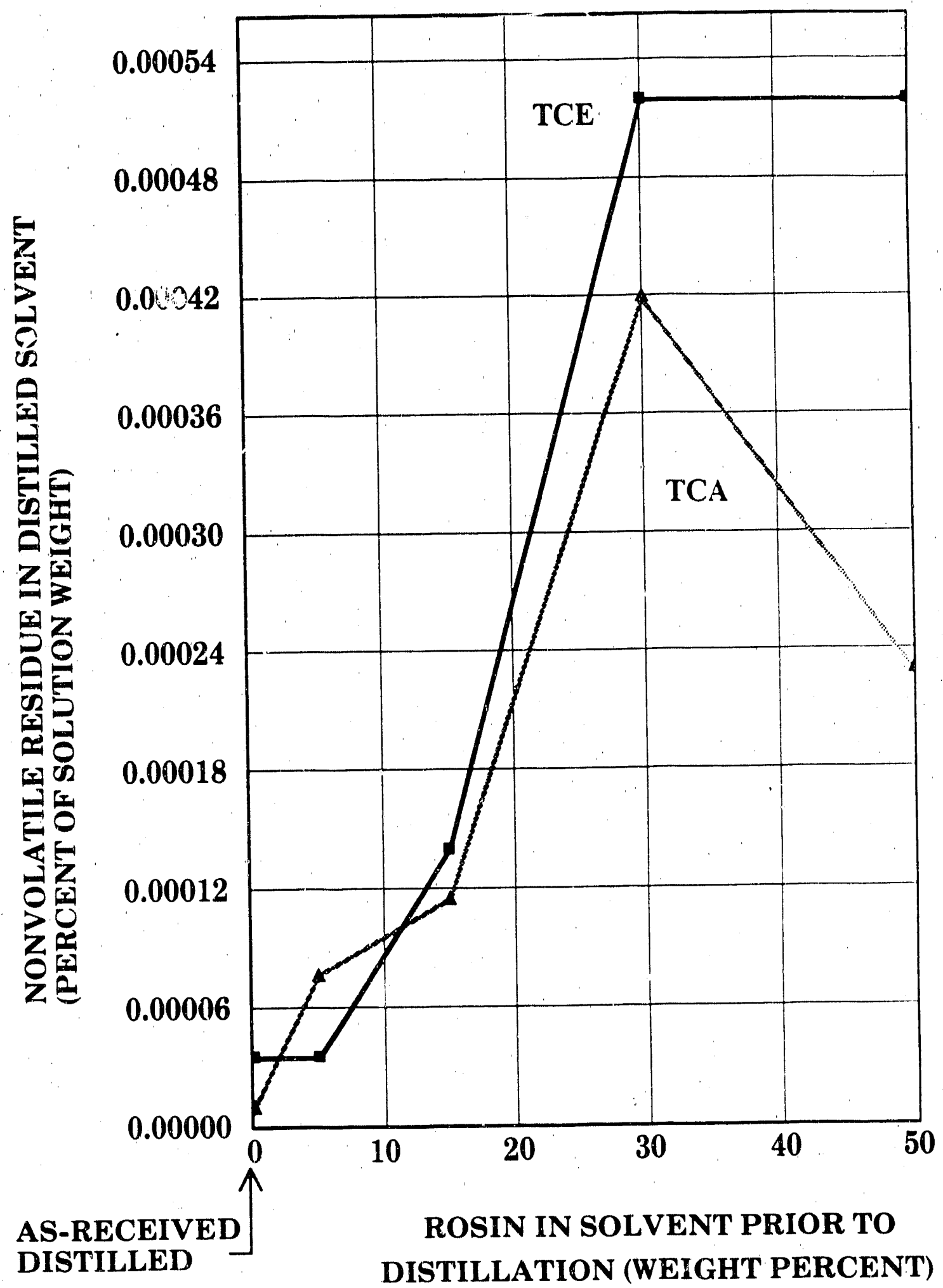

Figure 14. Nonvolatile kesidue Carried Over in the Distillation Process of Technical Grade Trichloroethylene and $1,1,1-\operatorname{Tr}$ ichloroethane 
Table 10. Nonvolatile Carryover During Distillation of

Contaminated Solutions From Various Manufacturing Departments Compared With Vendor Chemicals

\begin{tabular}{|c|c|c|c|c|c|c|}
\hline \multirow{2}{*}{$\begin{array}{l}\text { Source and } \\
\text { Date of } \\
\text { Contaminated } \\
\text { Solutton }\end{array}$} & \multirow[b]{2}{*}{ Solvent } & \multirow{2}{*}{$\begin{array}{l}\text { Nonvolatíle } \\
\text { Residue } \\
\text { (percent } \\
\text { by welght). }\end{array}$} & \multirow{2}{*}{$\begin{array}{l}\text { Evaporated } \\
\text { Solution } \\
\text { Stzo } \\
\text { (grams) }\end{array}$} & \multicolumn{2}{|c|}{$\begin{array}{l}\text { Predistllled } \\
\text { Contamtnation } \\
\text { Source } \\
\text { Level } \\
\text { (percent } \\
\text { by weight) }\end{array}$} & \multirow{2}{*}{$\begin{array}{l}\text { Equipment } \\
\text { Description }\end{array}$} \\
\hline & & & & Inttlal & Final & \\
\hline Sump, Distilled & $\begin{array}{l}\text { Prelete } \\
\text { (TCA) }\end{array}$ & 0.00045 & 112.18 & 1.0 & 2.1 & Vapor Degreaser \\
\hline $\begin{array}{c}\text { Can, D1st1lled } \\
10-27-88\end{array}$ & TCE & 0.00028 & 359.47 & 0.32 & 0.63 & Spray Booth \\
\hline $\begin{array}{c}\text { Can, Distilled } \\
10-31-88\end{array}$ & TCE & 0.00012 & 341.43 & 0.41 & 0.81 & $\begin{array}{l}\text { Spray Booth } \\
\text { Control }\end{array}$ \\
\hline $\begin{array}{l}\text { Sump, D1stf11 led } \\
11-5-88\end{array}$ & TCA & $<0.00001$ & 326.74 & 0.15 & 0.30 & Vapor Degreaser \\
\hline $\begin{array}{c}\text { Can, Distilled } \\
10-27-88\end{array}$ & TCE & $<0.00001$ & 323.40 & 3.6 & 7.2 & Spray Booth \\
\hline Sump, Distilled & TCE & $<0.00001$ & 338.35 & 0.09 & 0.19 & Vapor Degreaser \\
\hline $\begin{array}{l}\text { Wand } \\
10-27-88\end{array}$ & TCE & 0.00096 & 349.26 & --- & --- & \\
\hline Sump, Distilled & TCE & 0.00014 & 352.82 & 0.5 & 1.0 & Vapor Degreaser \\
\hline $\begin{array}{l}\text { Wand } \\
\qquad 10-31-88\end{array}$ & TCE & 0.00018 & 374.75 & 0.5 & 1.0 & Vapor Degreaser \\
\hline \multicolumn{7}{|c|}{ As-Recetved Solvents } \\
\hline \multicolumn{7}{|c|}{ Technitcal Grade TCE, 5-gallon can } \\
\hline $\begin{array}{l}\text { As-Recelved } \\
\text { As-Recefved }\end{array}$ & stilled & $\begin{array}{l}0.00138 \\
0.00004\end{array}$ & $\begin{array}{l}338.73 \\
287.66\end{array}$ & & & \\
\hline \multicolumn{7}{|c|}{ Technical Grade TCA, 1-gallon glass jar } \\
\hline As-Received & & 0.00178 & 242.08 & & & \\
\hline As-Recelved & stilled & $<0.00001$ & 127.60 & & & \\
\hline $\begin{array}{c}\text { Prelete, 5-gallo } \\
\text { As-Recelved } \\
\text { As-Recelved }\end{array}$ & stilled & $\begin{array}{l}0.00128 \\
0.00129\end{array}$ & $\begin{array}{l}202.40 \\
124.38\end{array}$ & & & \\
\hline
\end{tabular}




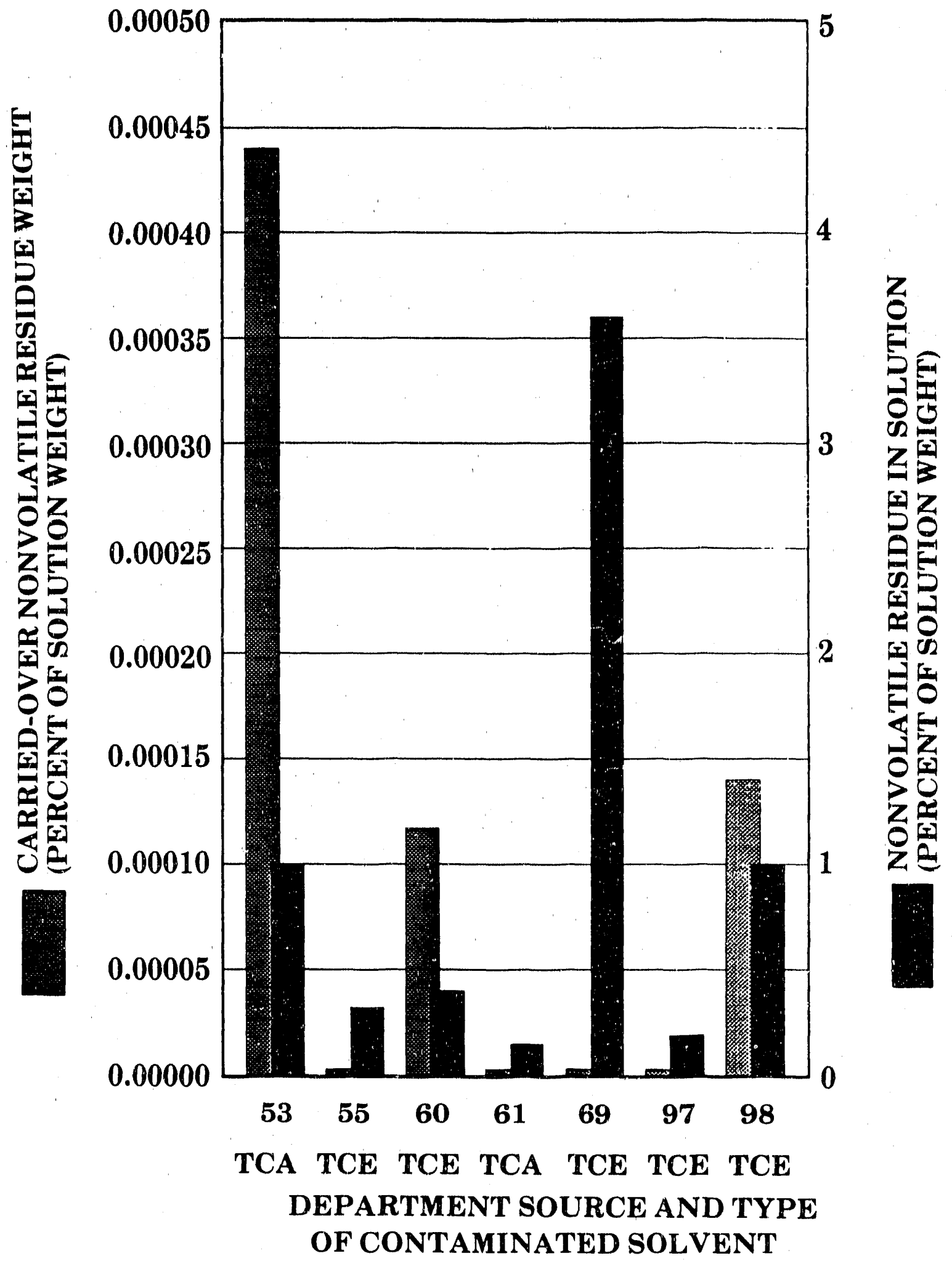

Fiqure 15. Nonvolatile Residue Carried Over in the Distillation Process of Contaminated Solvent From Various Departments 
Antoine's equation is

$\log 10[P(T)]=A-\frac{B}{[C+T(C)]}$,

where $A, B$, and $C$ are the Antoine constants for the solvent, $T(C)$ is the temperature in degrees Celsius, and $P(T)$ is pressure in millimeters of mercury. The Antoine constants for TCE and TCA are given in Table 11. To avoid the confusion of temperature being in both kelvins and Celsius, the substitution of $T(C)=$ $T(k)-273.3$ will be used. So we have

$\log 10[P(T)]=A-\frac{B}{[C+T(k)-273.31]}$.

The amount of solvent per volume as a function of temperature is then

$$
D=\frac{m 10}{R T(k)}, \text {. }
$$

where $\mathrm{m}(\mathrm{TCE}) \overline{\overline{3}} 0.291281 \mathrm{~b} / \mathrm{mol}, \mathrm{m}(\mathrm{TCA})=0.29348 \mathrm{lb} / \mathrm{mol}$, $R=2.2024 \mathrm{ft}^{3} \cdot \mathrm{mmHg} / \mathrm{mol} \cdot \mathrm{K}$, and $\mathrm{D}$ is in $\mathrm{lb} / \mathrm{ft}^{3}$. The results of calculations showing how the solvent vapor density varies with the temperature are given in Table 12 .

\section{Eire Safety}

The solvents TCE and TCA have no flash point or fire point as determined by standard tests. However, these solvents do have flammable limits in air and have a flammable range when high concentrations are mixed in air (see Table l) and exposed to a high-energy source. At $100^{\circ} \mathrm{C}$ the flammable limits in air of TCE increase to the 52-percent concentration level.1 " For this reason, only electrical equipment approved for use in hazardous locations is recommended for use in closed tanks, in areas where high vapor concentrations may occur because of a spill or other mishap, or in other locations where high concentrations of solvent vapor may accumulate. ${ }^{\text {s }}$

Lab experiments performed show that TCE and TCA will continue to burn as long as they are exposed to an open flame. TCE and TCA give off chlorine and other toxic gases when burning. The presence of rosin did not appear to increase the fire hazard of these solvents. A simple experiment exposing 30- and 50-percent solutions to open flame produced reactions similar to those of 
Table 11. Antoine Constants for Trichloroethylene and $1,1,1-T r i c h l o r o e t h a n e$

\begin{tabular}{lcc}
\hline Constant & Trichloroethylene* & $1,1,1-$ Trichloroethane** \\
\hline A & 7.11886 & 6.92654 \\
B & 1367.05 & 1215.94 \\
C & 235.809 & 226.503 \\
\hline *Applies from -86 to $86^{\circ} \mathrm{C}$. & \\
**Applies from -30 to $74^{\circ} \mathrm{C}$. & \\
\hline
\end{tabular}

uncontaminated solutions; one would expect this from the distillation experiments that show very little rosin goes into vapor. At very high (greater than 90-percent) rosin concentrations, the rosin can be ignited and will continue to burn with the smali amount of solvent present.

\section{Health Safety}

Health and safety data of fluorinated, chlorinated, and a few other solvents are given in Table 13.14 s other general. properties of TCE and TCA were given in Table 1. " It is apparent from Table 13 that if one can smell the solvent, there is too much in the air. OSHA has proposed a reduction in the threshold limit value-time weighted average (TLV-TWA) values for some of these solvents, and further reductions could make using them more difficult and less desirable." "

A white paper issued by the Halogenated Solvents Industry Alliance (HSIA) brought out recent $f$ indings that laboratory rats metabolize solvents in a different manner than humans, and, therefore, the conclusions of the toxicology studies implicating TCE and TCA are invalid.1\%1\% Independent of these findings, the solvents' known toxicity and the hazardous waste produced from cleaning with them requires that improvements be made in their use. Restrictions on these solvents by government agencies are not likely to be removed. For these reasons, a vapor-containing cleaning system is needed that will minimize atmospheri= emissions and exposure of personnel to solvent.

\section{ACCOMPL I SHMENTS}

The physical properties of contaminated trichloroethylene and 1,1,1-trichloroethane were characterized. The specific gravity, volume change, dielectric constant, dissipation factor, boiling point, and nonvolatile residue carryover during aistillation were 
Table 12. Solvent Density and PPM Level for Various Temperatures of Air

\begin{tabular}{|c|c|c|c|c|c|}
\hline \multicolumn{2}{|c|}{ Temperature } & \multicolumn{2}{|c|}{$\begin{array}{l}\text { Sulvent Vapor Density } \\
\left(1 \mathrm{~b} / \mathrm{ft}^{3}\right) *\end{array}$} & \multicolumn{2}{|c|}{ Solvent Leve1** } \\
\hline$\cdot \mathrm{C}$ & $\cdot F$ & TCE & TCA & TCE (\%) & $\operatorname{TCA}(\%)$ \\
\hline $\begin{array}{r}37.7 \\
32.2 \\
26.7 \\
10.0 \\
6.1\end{array}$ & $\begin{array}{r}100 \\
90 \\
80 \\
50 \\
43\end{array}$ & $\begin{array}{l}0.056 \\
0.045 \\
0.036 \\
0.017 \\
0.014\end{array}$ & $\begin{array}{l}0.090 \\
0.073 \\
0.059 \\
0.029 \\
0.024\end{array}$ & $\begin{array}{l}22 \\
18 \\
14 \\
6.7 \\
5.5\end{array}$ & $\begin{array}{l}39 \\
32 \\
26 \\
1.3 \\
10\end{array}$ \\
\hline $\begin{array}{r}0 \\
-10 \\
-20 \\
-30 \\
-40\end{array}$ & $\begin{array}{r}32 \\
14 \\
-4 \\
-22 \\
-40\end{array}$ & $\begin{array}{l}0.010 \\
0.0058 \\
0.0032 \\
0.0016 \\
0.00078\end{array}$ & $\begin{array}{l}0.018 \\
0.010 \\
0.0057 \\
0.0030 \\
0.0021\end{array}$ & $\begin{array}{l}3.9 \\
2.3 \\
1.25 \\
0.62 \\
0.31\end{array}$ & $\begin{array}{l}7.8 \\
4.3 \\
2.5 \\
1.3 \\
0.91 \\
(9100 \mathrm{ppm})\end{array}$ \\
\hline $\begin{array}{l}-50 \\
-60 \\
-70 \\
-80 \\
-86\end{array}$ & $\begin{array}{r}-58 \\
-76 \\
-94 \\
-112 \\
-123\end{array}$ & $\begin{array}{l}0.00034 \\
0.00014 \\
0.000049 \\
0.000015 \\
0.000007\end{array}$ & $\begin{array}{l}-- \\
-- \\
-- \\
--\end{array}$ & $\begin{array}{r}1300 \mathrm{ppm} \\
550 \mathrm{ppm} \\
193 \mathrm{ppm} \\
59 \mathrm{ppm} \\
28 \mathrm{ppm}\end{array}$ & $\begin{array}{l}- \\
-- \\
-- \\
-- \\
--\end{array}$ \\
\hline
\end{tabular}

*Calculated using Antoine's constants from Table 11.

**After removal of condensed solvent and returning to standard temperature and pressure.

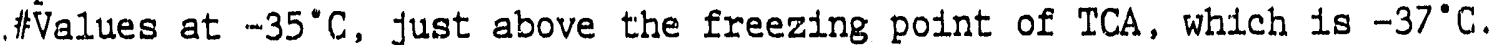

measured for various contamination levels of rosin in trichloroethylene and 1,1,1-trichloroethane. Solvent stabilizers and the vapor pressure of solvents were also examined. The effects of oil contamination on the boiling point were also examined.

The data obtained in this effort supported the design of the new vapor-containing cleaning system that will meet the demands of new environmental and health restrictions and maintain the high level of cleaning needed on electronic assemblies. These data eliminated the unknowns in the area of contamination carryover and physical property changes that could be monitored to indicate contamination level.

FUTURE WORK

Two practical applications to environmental waste are suggested below. No future work in characterization of contaminated solvents is planned as part of this project at the present time. 
Table 13. Health and Safety Data for Solvents

Solvent Odor*

\begin{tabular}{|c|c|c|c|}
\hline Solvent & $\begin{array}{l}\text { Odor } \\
\text { Threshold }\end{array}$ & $\begin{array}{l}\text { S11ght, } \\
\text { Not Unpleasant }\end{array}$ & $\begin{array}{l}\text { Strong, } \\
\text { Unpleasant }\end{array}$ \\
\hline $\begin{array}{l}\text { Trichloroethy lene } \\
\text { 1,1,1-Tr1ch1oroetharle } \\
\text { (Methy 1 Ch1oroform) }\end{array}$ & $100-50$ & $\begin{array}{l}100-400 \\
350-500\end{array}$ & $\begin{array}{r}>1000 \\
>900\end{array}$ \\
\hline $\begin{array}{l}\text { Perchloroethylene } \\
\text { Methylene Chlorlde }\end{array}$ & $\begin{array}{c}5-70 \\
150-600\end{array}$ & $\begin{array}{l}100-200 \\
250-1000\end{array}$ & $\begin{array}{r}>280 \\
>1000\end{array}$ \\
\hline \multicolumn{4}{|l|}{ OSHA Exposure Limits* } \\
\hline Solvent & $\begin{array}{l}\text { 8-Hour** } \\
\text { T1me-We1ghted } \\
\text { Average }\end{array}$ & $\begin{array}{l}\text { Acceptable } \\
\text { Celling } \\
\text { Concentration }\end{array}$ & $\begin{array}{l}\text { Maxlmum } \\
\text { Acceptable } \\
\text { Peak }\end{array}$ \\
\hline Trichloroethylene & $50 \quad(25) * \star *$ & 200 & $\begin{array}{l}300 \text { for } 5 \mathrm{~min} \\
\text { in any } 2 \mathrm{~h}\end{array}$ \\
\hline 1,1,1-Tr1ch1oroethane & 350 & $-m$ & 450 for $15 \mathrm{~m} 1 \mathrm{n}$ \\
\hline Perchloroethylene & 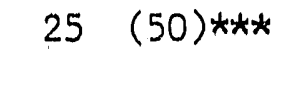 & 200 & $\begin{array}{c}300 \text { for } 5 \mathrm{~min} \\
\text { In any } 3 \mathrm{~h}\end{array}$ \\
\hline Methylene Chlorlde & 500 & 1000 & $\begin{aligned} 2000 \text { for } 5 \mathrm{~min} \\
\text { In any } 2 \mathrm{~h}\end{aligned}$ \\
\hline $\begin{array}{l}\text { Methylethylketone (MEK) } \\
\text { Isopropy1 Alcohol } \\
\text { Geneso1v DFX } \\
\text { Geneso1v DM } \\
\text { Acetone }\end{array}$ & $\begin{array}{l}200 \\
400 \\
480 \\
600 \\
750\end{array}$ & $\begin{array}{c}-\infty \\
-- \\
-\infty\end{array}$ & $\begin{array}{c}-- \\
-\infty \\
-\infty\end{array}$ \\
\hline
\end{tabular}

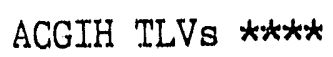

TLV*

Time-Welghted Short-Term (15 min)

Solvent

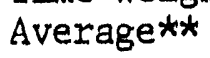
Exposure LImit非

Trichloroethylene

1,1,1-Trichloroethane

(Methy1 Ch1oroform)

Perchloroethylene

Methylene Chlorlde

Methylethylketone

(MEK)

Isopropy1 Alcohol

Genesolv DFX

50

350

200

450

Geneso1v DM

Acetone

$\begin{array}{rc}50 & 200 \\ 50 & -- \\ 200 & 300 \\ 400 & 500 \\ 480 & \\ 140 & \\ 750 & 1000\end{array}$


Table 13 Continued. Health and Safety Data for Solvents

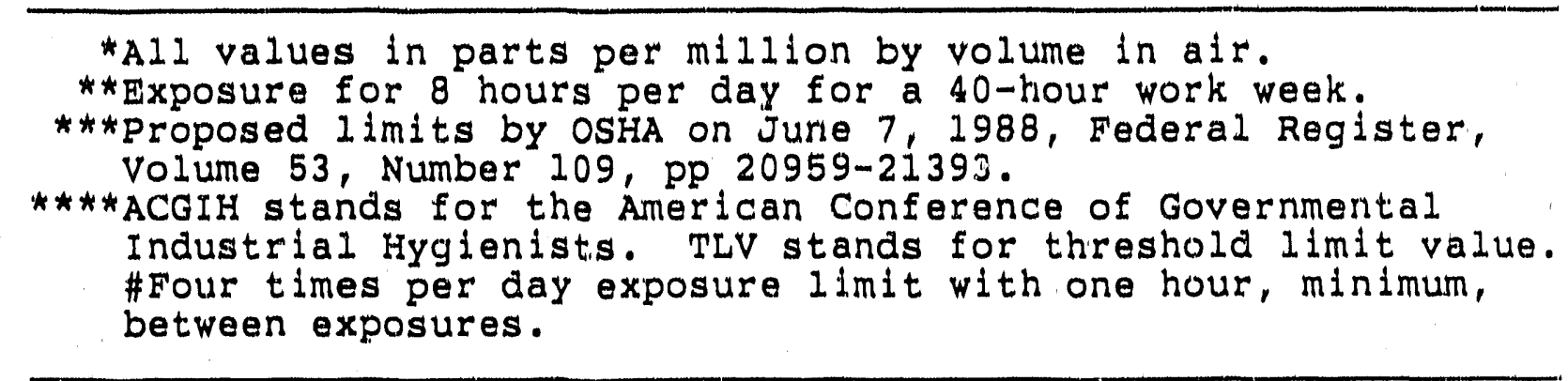

Laboratory analysis of solvents contaminated with olis is an important effort that should be completed.

Solvent recovery must start with accurately identifying the solvent. If cross-contamination of solvents occurs in a recycling batch, all the solvent could be lost and the stili damaged. Measurements of the dielectric constant and dissipation factor of TCE and TCA contaminated with rosin indicate that these properties may be used as a fast and inexpensive indicator of which solvent is in a waste container (see Figures 5 and 6). To a limited degree, the amount of contamination in the solvent may be estimated by measuring the dielectric constant and dissipation factor, Efforts should be dedicated toward using this method for solvent recovery process control.

High weight percent contaminated solvent waste is not recoverable at and above the 90-percent level because of the need to drain the waste from the still. Recycling high weight percent contaminated solvent waste may require an alternate recycling method from what is typically used. Recycling solvent waste is a distillation process that normally does not take the sump to diyness; the residue, still a liquid, is drained and disposed of as hazardous waste.

Over 90-percent of the solvent could be recovernd and the residue could be disposed of as nonhazardous waste (assuming the contamination is rosin) if a temperature-controlled heat source heated the residue until it was completely dry. The waste could be boiled dry in a thin disposable iner, removed, and disposed of. This recovery approach, if 95-percent efficient, could reduce the solvent waste to 0.05 times the weight of the contaminant. 


\section{REFERENCES}

'R. J. Cicerone, "Changes in Stratospheric Ozone." Science, Volume 237, July 3, 1987, pp 35-42.

"Anonymous, "Ozone Depletion at the Poles: The Hole Story Emerges." Bhysias Loday, July 1988, pp 17-21.

"R. A. Kerr, "Has Stratospheric Ozone Started to Disappear?" Science, Volume 237, July 10, 1987, pp 131-2.

"M. Crawford, "EPA to Cut U.S. CFC Production to protect Ozone in Stratosphere." Science, December 11, 1987, p 1505.

"Nations agree on plan to preserve ozone." from the New York Times, printed in the Kansas City Times, september 17, 1987, p A-3.

"EPA urges fast action to curb loss of ozone." The Washington Post, Reprinted in the Kansas City Times, Tuesday, September 27 , $1.988, \mathrm{p} \mathrm{A}-3$.

${ }^{7} R$. J. K. Wassink, Soldering in Electrontese Scotland: Electrochemical publications Limited, 1984, pp 151-153.

'R. C. Weast, editor, Handbook of Chemistry and Physics, 58 th Edition. Cleveland, OH: The Chemical Rubber Company, 1977-1978, pp C-81, C-440, and $D-180$.

J. A. Riddick and $W$. B. Bunger, "Organic solvents, Physical Properties and Methods of Purification" in Techniques cif erganic Solvents, Volume II. Wiley-Interscience Pub., 1970.

${ }^{\circ} \mathrm{E}$. U. Concon and H. Odishaw, editors, Handboek of Physics, Second Edition, McGraw Hill publishers, 1978, pp 4-103.

${ }^{2}$ C. E. Mortimer, Chamistry, A Cenceptual Approach, Thited Edition. D. Van Nostrand Co. Pub., 1975.

$12 \mathrm{~J}$. A. McIntyre and R. A. MCDonald, "Concentration of oil in the Vapor Zone of Vapor Degreasers." Rlating, June 1973.

${ }^{2} \mathrm{H}$. H. Manko, Solders and Soldering Second Edition, 1979, pp 36-37.

1 'Solvent Data Sheets for TCE and 1,1,1-TCA. PPG Industries, Inc. Pittsburg, FA.

1 "Specially Chloxinated Selyents Product Stewardshin Manual -Safety, Health, Environmental Aspects, Bulk Handling, 1988/1989 Edition, Dow Chemical Company. 
'Federal Reglster, Volume 53, Number 109, June 7, 1988, pp 0959-21393.

1"White paper on Trichloroethylene. Washington, D.C.: Halogenated Solvents Industry Alliance, November 1986.

1"White Paper on 1,1,1-Trichloroethane. Washington, D.C.: Halogenated Solvents Industry Alliance, June 1987. 
Appendix A

ELECTRICAL PROPERTY MEASUREMENTS OF

AS-RECEIVED AND ROSIN-CONTAMINATED

TR I CHLOROETHYLENE AND 1,1,1-TRICHLOROETHANE 
MATERIALS AND PROCEDURE

This work was accomplished during september ard october 1988.

\section{SOLVENTS AND ROSIN}

The trichloroethylene (TCE) used in ald the laboratory

experiments was from one 5-galion can of technical grade solvent. The trichloroethane (TCA) used in all the laboratory experiments was from one lot of technical grade solvent supplied in I-galion glass containers.

The rosin used in the experiments was taken from two solder fluxes which meet MIL-F-14256 specification as types $R$ and RMA. The rosin solvent carrier (alcohoil) in the flux was removed by elevating the flux temperature to 80 to $90^{\circ} \mathrm{C}$ for 16 to 48 hours $\left(90^{\circ} \mathrm{C}\right.$ is well below the bolling point of the flux and rosin).

\section{DIELECTRIC CONSTANT}

The dielectric constant of contaminated solutions was measured using a guarded-ring parallel-plate capacitor and making capacitance measurements. Capacitance measurements were made using a capacitance test cell and an automatic capacitance bridge. The test cell had a micrometer adjustment with 0.001-1nch markings for the parallel plate spacing and had a guard ring to eliminate fringe effects. The paraliel plate was 2.0 inches in diameter with a 0.2 -inch wide circumferential guard ring. The capacitance bridge was accurate to \pm 1 percent for the capacitance values measured and all measurements were made at room temperature. Capacitance measurements were made at $10 \mathrm{kHz}, 100 \mathrm{kHz}$, and $1 \mathrm{MHz}$, with a few measurements at $1 \mathrm{kHz}$. Capacitance measurements were made at spacings of $0.050,0.100,0.150,0.200$, and 0.250 inch between the paralle. plates. The dielectric constant was calculated by using the equation

$\mathrm{K}=\frac{\mathrm{C} e}{\mathrm{Ca}}$,

where $C e$ is capacitance of the test cell filled with the solution and $\mathrm{Ca}$ is the capacitance of the test cell filled only with ajx.

\section{DISSIPATION FACTOR}

Dissipation factor is a measure of the power loss when a material is used as a dielectric in a capacitor. The dissipation factor is also called the loss tangent and is defined as the ratio of the real impedance divided by the complex impedance of the dielectric. The dissipation factor was measured using the same 
equipment and procedure as was used for measuring the dielectric constant (Tables $A-1, A-2$, and $A-3$ ). The dissipation factor measurements at $1 \mathrm{MHz}$ were not very consistent. Values in parenthesis (Table $A-1$ ) were from measurements taken at a later date. Stable readings occurred in the 10- to $100-\mathrm{kHz}$ frequency range. 
Table A-1. Dissipation Factor and Capacitance Measurements of As-Recelved TCE and TCE Contaminated With ROsin

\begin{tabular}{|c|c|c|c|c|c|c|c|c|}
\hline \multirow{2}{*}{$\begin{array}{l}\text { Gap } \\
\text { Spac1ng } \\
\text { (Inch) }\end{array}$} & \multicolumn{4}{|c|}{ Capac1tance (pF) } & \multicolumn{4}{|c|}{ Dissipation Factor } \\
\hline & $1 \mathrm{kHz}$ & $10 \mathrm{kHz}$ & $100 \mathrm{kHiz}$ & $1 \mathrm{MHz}$ & $1 \mathrm{kHz}$ & $10 \mathrm{kHz}$ & $100 \mathrm{kHz}$ & $1 \mathrm{MHZ}$ \\
\hline \multicolumn{9}{|c|}{ Solution: } \\
\hline $\begin{array}{l}0.050 \\
0.100 \\
0.150 \\
0.200 \\
0.250\end{array}$ & $\begin{array}{r}21.56 \\
10.95 \\
7.34 \\
5.50 \\
4.39\end{array}$ & $\begin{array}{l}21.58 \\
10.970 \\
7.351 \\
5.518 \\
4.41 .0\end{array}$ & $\begin{array}{l}21.55 \\
10.966 \\
7.344 \\
5.511 \\
4.403\end{array}$ & $\begin{array}{r}21.72 \\
11.049 \\
7.399 \\
5.551 \\
4.435\end{array}$ & $\begin{array}{l}0 \\
0 \\
0 \\
0 \\
0\end{array}$ & $\begin{array}{l}0.0005 \\
0 \\
0.0001 \\
0.0002 \\
0.0002\end{array}$ & $\begin{array}{l}0.0001 \\
0.0003 \\
0.0006 \\
0.0008 \\
0.0012\end{array}$ & $\begin{array}{l}0.0003 \\
0 \\
0 \\
0 \\
0\end{array}$ \\
\hline
\end{tabular}

Solution: As-Recelved Technlcal Grade TCE (Measured 10-11-88)

\begin{tabular}{lllllllll}
\hline 0.050 & 74.86 & 74.86 & 74.86 & 76.05 & 0.0062 & 0.0008 & 0.0003 & 0.0016 \\
0.100 & 38.02 & 38.03 & 38.02 & 38.44 & 0.0062 & 0.0010 & 0.0010 & 0.0015 \\
0.150 & 25.44 & 25.47 & 25.45 & 25.70 & 0.0061 & 0.0010 & 0.0003 & 0.0016 \\
0.200 & 19.09 & 19.12 & 19.10 & 19.26 & 0.0060 & 0.0012 & 0.0005 & 0.0027 \\
0.250 & 15.25 & 15.280 & 15.276 & 15.434 & 0.0060 & 0.0007 & 0.0018 & -
\end{tabular}

Ave. Dlelectrlc Constant $3.468 \quad 3.476$

Solution: As-Recelved Technlcal Grade TCE (Measured 11-5-88)

\begin{tabular}{lllllllll}
\hline 0.050 & 75.33 & 75.36 & 75.34 & 76.52 & 0.0062 & 0.0007 & 0.0003 & 0.0006 \\
0.100 & 38.27 & 38.29 & 38.28 & 38.70 & 0.0061 & 0.0009 & 0.0002 & 0.0004 \\
0.150 & 25.63 & 25.64 & 25.63 & 25.87 & 0.0061 & 0.0012 & 0.0003 & 0.0003 \\
0.200 & 19.24 & 19.25 & 1.9 .25 & 19.42 & 0.0060 & 0.0012 & 0.0002 & 0.0005 \\
0.250 & 15.37 & 15.404 & 15.499 & 15.555 & 0.0058 & 0.0005 & 0.0002 & 0.0000
\end{tabular}

Ave. Dielectric Constant $3.495 \quad 3.501$

Solut1on: As-Recelved--In storage bottle for 25 davs (Measured 11-5-88)

\begin{tabular}{lllllllll}
\hline 0.050 & 75.16 & 75.18 & 75.16 & 76.33 & 0.0162 & 0.0018 & 0.0004 & 0.0020 \\
0.100 & 38.17 & 38.19 & 38.17 & 38.57 & 0.0170 & 0.0020 & 0.0002 & 0.0008 \\
0.150 & 25.59 & 25.61 & 25.59 & 25.83 & 0.0175 & 0.0022 & 0.0004 & 0.0009 \\
0.200 & 19.22 & 19.25 & 19.23 & 19.40 & 0.0170 & 0.0023 & 0.0004 & 0.0009 \\
0.250 & 15.35 & 15.390 & 15.385 & 15.537 & 0.0166 & 0.0016 & 0.0004 & 0.0003
\end{tabular}

Ave. Dlelectrlc Constant $3.488 \quad 3.495$ 
Table A-1 Continued. Dissipation Factor and Capacitance Measurements of As-Received TCE and TCE Contaminated With Rosin

\begin{tabular}{|c|c|c|c|c|c|c|c|c|}
\hline \multirow{2}{*}{$\begin{array}{l}\text { Gap } \\
\text { Spacing } \\
\text { (inch) }\end{array}$} & \multicolumn{4}{|c|}{ Capacitance (pF) } & \multicolumn{4}{|c|}{ Dissipation Factor } \\
\hline & $1 \mathrm{kHz}$ & $10 \mathrm{kHz}$ & $100 \mathrm{kHz}$ & $1 \mathrm{MHz}$ & $1 \mathrm{kHz}$ & $10 \mathrm{kHz}$ & $100 \mathrm{kHz}$ & $1 \mathrm{MHz}$ \\
\hline \multicolumn{9}{|c|}{ Solution: } \\
\hline $\begin{array}{l}0.050 \\
0.100 \\
0.150 \\
0.200 \\
0.250\end{array}$ & $\begin{array}{l}74.69 \\
37.95 \\
25.46 \\
19.12 \\
15.27\end{array}$ & $\begin{array}{l}74.70 \\
37.98 \\
25.46 \\
19.14 \\
15.306\end{array}$ & $\begin{array}{l}74.69 \\
37.96 \\
25.46 \\
19.12 \\
15.300\end{array}$ & $\begin{array}{l}75.84 \\
38.37 \\
25.68 \\
19.28 \\
15.447\end{array}$ & $\begin{array}{l}0.0161 \\
0.0161 \\
0.0160 \\
0.0160 \\
0.0160\end{array}$ & $\begin{array}{l}0.0018 \\
0.0018 \\
0.0020 \\
0.0023 \\
0.0016\end{array}$ & $\begin{array}{l}0.0003 \\
0.0002 \\
0.0004 \\
0.0003 \\
0.0003\end{array}$ & $\begin{array}{l}0.0006 \\
0.0004 \\
0.0004 \\
0.0003 \\
0.0000\end{array}$ \\
\hline Ave. $\mathrm{D} 1$ & electri & Coisstar & 3.468 & 3.475 & & & & \\
\hline
\end{tabular}

Solution: 0.1-Percent Rosin frow Flux A (Measured 11-5-88)

\begin{tabular}{lllllllll}
\hline 0.050 & 74.69 & 74.73 & 74.71 & 75.85 & 0.0241 & 0.0025 & 0.0004 & 0.0006 \\
0.100 & 37.99 & 38.01 & 37.98 & 38.40 & 0.0240 & 0.0028 & 0.0003 & 0.0005 \\
0.150 & 25.44 & 24.47 & 25.45 & 25.69 & 0.0241 & 0.0028 & 0.0004 & 0.0004 \\
0.200 & 19.13 & 19.14 & 19.12 & 19.29 & 0.0240 & 0.0030 & 0.0005 & 0.0005 \\
0.250 & 15.28 & 15.312 & 15.307 & 15.454 & 0.0240 & 0.0024 & 0.0004 & 0.0001
\end{tabular}

Ave. Dielectric Constant $3.469 \quad 3.477$

Solution: 0.5-Percent Rosin from Flux A (Measured 11-5-88)

\begin{tabular}{lllllllll}
\hline 0.050 & 74.82 & 74.84 & 74.82 & 75.97 & - & - & - & - \\
0.100 & 38.04 & 38.06 & 38.04 & 38.45 & 0.0657 & 0.0070 & 0.0007 & 0.0005 \\
0.150 & 25.48 & 25.50 & 25.48 & 25.72 & 0.0656 & 0.0070 & 0.0009 & 0.0005 \\
0.200 & 19.13 & 19.16 & 19.14 & 19.31 & 0.0656 & 0.0072 & 0.0008 & 0.0006 \\
0.250 & 15.29 & 15.323 & 15.319 & 15.466 & 0.0656 & 0.0064 & 0.0008 & 0.0000
\end{tabular}

Ave. Dielectric Constant $3.473 \quad 3.481$

Solution: 1.0-Percent Rosin from Flux A (Measured 11-5-88)

\begin{tabular}{lllllllll}
\hline 0.050 & 74.77 & 74.79 & 74.77 & 75.93 & 0.1061 & 0.0108 & 0.0010 & 0.0006 \\
0.100 & 38.07 & 38.08 & 38.07 & 38.49 & 0.1060 & 0.0109 & 0.0013 & 0.0005 \\
0.150 & 25.48 & 25.51 & 25.49 & 25.73 & 0.1059 & 0.0110 & 0.0011 & 0.0005 \\
0.200 & 19.16 & 19.17 & 19.14 & 19.32 & 0.1056 & 0.0112 & 0.0012 & 0.0006 \\
0.250 & 15.30 & 15.333 & 15.329 & 15.476 & 0.1057 & 0.0105 & 0.0012 & 0.0000
\end{tabular}

Ave. Dielectric Constant $3.474 \quad 3.482$ 
Table A-1 Continued. Dissipation Factor and Capacitance

Measurements of As-Received TCE and TCE Contaminated With Rosin

\begin{tabular}{llllll}
\hline $\begin{array}{l}\text { Gap } \\
\text { Spacing } \\
\text { (Inch) }\end{array}$ & Capacitance (pF) & \multicolumn{3}{l}{ Dissipation Factor } \\
\cline { 2 - 3 } & $1 \mathrm{kHz} \quad 10 \mathrm{kHz}$ & $100 \mathrm{kHz} \quad 1 \mathrm{MHz}$ & $1 \mathrm{kHz} \quad 10 \mathrm{kHz} \quad 100 \mathrm{kHz} \quad 1 \mathrm{MHz}$ \\
\hline
\end{tabular}

Solution: 3.0-Pexcent Rosin from F1ux A (Measured 11-5-88)

\begin{tabular}{lllllllll}
\hline 0.050 & 75.16 & 75.17 & 75.15 & 76.32 & 0.2419 & 0.0244 & 0.0025 & 0.0009 \\
0.100 & 38.17 & 38.19 & 38.17 & 38.58 & 0.2419 & 0.0246 & 0.0024 & 0.0007 \\
0.150 & 25.57 & 25.59 & 25.57 & 25.81 & 0.2419 & 0.0246 & 0.0025 & 0.0007 \\
0.200 & 19.20 & 19.22 & 19.21 & $1 . .38$ & 0.2418 & 0.0250 & 0.0026 & 0.0007 \\
0.250 & 15.35 & 15.376 & 15.373 & 15.525 & 0.2417 & 0.0241 & 0.0026 & 0.0001
\end{tabular}

Ave. Dielectric Constant $3.486 \quad 3.493$

Solution: 5-Percent Rosin from Flux A (Measured 10-11-88)

\begin{tabular}{lllllllll}
\hline 0.050 & 75.47 & 75.47 & 75.45 & 76.65 & 0.3628 & 0.0365 & 0.0039 & 0.0020 \\
0.100 & 38.32 & 38.33 & 38.33 & 38.75 & 0.3628 & 0.0367 & 0.0037 & 0.0016 \\
0.150 & 25.65 & 25.66 & 25.63 & 25.89 & 0.3627 & 0.0367 & 0.0039 & 0.0016 \\
0.200 & 19.26 & 19.26 & 19.25 & 19.43 & 0.3629 & 0.0370 & 0.0039 & 0.0017 \\
0.250 & 15.39 & 15.41 & 15.41 & 15.58 & 0.3632 & 0.0363 & 0.0038 & 0.0011
\end{tabular}

Ave. Dielectric Constant $3.500 \quad 3.505$

Solution: 10-Percent Rosin from Flux A (Measured 10-11-88)*

\begin{tabular}{lllllllll}
\hline 0.050 & 76.15 & 76.17 & 76.15 & 77.42 & 0.5488 & 0.0552 & 0.0056 & $0.0026(14)$ \\
0.100 & 38.66 & 38.67 & 38.67 & 39.08 & 0.5487 & 0.0555 & 0.0059 & $0.0029(13)$ \\
0.150 & 25.89 & 25.90 & 25.88 & 26.11 & 0.5485 & 0.0555 & 0.0059 & $0.0041(14)$ \\
0.200 & 19.44 & 19.45 & 19.42 & 19.61 & 0.5486 & 0.0556 & 0.0058 & $0.0019(13)$ \\
0.250 & 15.52 & 15.54 & 15.55 & 15.72 & 0.5490 & 0.0549 & 0.0058 & $0.0018(08)$
\end{tabular}

Ave. Dielectric Constant $3.529 \quad 3.614$

Solution: 15-Percent Rosin from Flux A (Measured 10-11-88)*

\begin{tabular}{lllllllll}
\hline 0.050 & - & 76.67 & 76.65 & 77.94 & - & 0.1010 & 0.0105 & $0.0049(23)$ \\
0.100 & - & 38.89 & 38.85 & 39.39 & -- & 0.1012 & 0.0103 & $0.0038(22)$ \\
0.150 & - & 26.04 & 26.02 & 26.30 & - & 0.1014 & 0.0103 & $0.0030(20)$ \\
0.200 & - & 19.55 & 19.53 & 19.70 & - & 0.1016 & 0.0104 & $0.0033(18)$ \\
0.250 & - & 15.61 & 15.62 & 15.79 & - & 0.1008 & 0.0105 & $0.0019(22)$
\end{tabular}

Ave. Dielectric Constant $3.548 \quad 3.555$ 
Table A-1 Continued. Dissipation Factor and Capacitance

Measurements of As-Received TCE and TCE Contaminated With Rosin

\begin{tabular}{llllll}
\hline $\begin{array}{l}\text { Gap } \\
\text { Spacing } \\
\text { (1nch) }\end{array}$ & Capac1tance (pF) & \multicolumn{3}{l}{ Dissipation Factor } \\
\hline
\end{tabular}

Solution: 20-Percent Rosin from Flux A (Measured 10-11-88)*

\begin{tabular}{lllllllll}
\hline 0.050 & - & 77.52 & 77.49 & 78.81 & - & 0.0801 & 0.0084 & $0.0043(23)$ \\
0.100 & - & 39.36 & 39.34 & 39.77 & - & 0.0802 & 0.0082 & $0.0032(23)$ \\
0.150 & - & 26.36 & 26.35 & 26.66 & -- & 0.0804 & 0.0086 & $0.0074(23)$ \\
0.200 & - & 19.80 & 19.78 & 19.96 & -- & 0.0804 & 0.0083 & $0.0032(19)$ \\
0.250 & - & 15.82 & 15.83 & 15.97 & -- & 0.0797 & 0.0088 & $0.0083(21)$
\end{tabular}

Ave. Dielectric Constant $3.593 \quad 3.600$

Solution: 25-Percent Rosin from Flux B (Measured 10-11-88)*

\begin{tabular}{lllllllll}
\hline 0.050 & - & 77.99 & 77.96 & 79.29 & - & 0.1020 & 0.0105 & $0.0033(26)$ \\
0.100 & - & 39.59 & 39.56 & 40.03 & - & 0.1023 & 0.0106 & $0.0037(27)$ \\
0.150 & - & 26.51 & 26.49 & 26.73 & -- & 0.1026 & 0.0108 & $0.0050(26)$ \\
0.200 & - & 19.92 & 19.90 & 20.08 & - & 0.1029 & 0.0105 & $0.0033(23)$ \\
0.250 & - & 15.91 & 15.93 & 16.04 & - & 0.1034 & 0.0107 & $0.0028(30)$
\end{tabular}

Ave. Dielectric Constant $3.613 \quad 3.618$

Solution: 30-Percent Rosin from F1ux B (Measured 10-11-88)*

\begin{tabular}{lllllllll}
\hline 0.050 & - & 78.29 & 78.27 & 79.59 & - & 0.0515 & 0.0056 & $0.0045(31)$ \\
0.100 & - & 39.71 & 39.69 & 40.12 & - & 0.0514 & 0.0054 & $0.0039(31)$ \\
0.150 & - & 26.61 & 26.58 & 26.84 & - & 0.0514 & 0.0053 & $0.0024(31)$ \\
0.200 & - & 19.98 & 19.97 & 20.14 & - & 0.0515 & 0.0053 & $0.0022(30)$ \\
0.250 & - & 15.96 & 15.97 & 16.08 & -- & 0.0516 & 0.0053 & $0.0027(30)$
\end{tabular}

Ave. Dielectric Constant $3.623 \quad 3.628$

Solution: 30-Percent Rosin from F1ux B (Measured 10-11-88)*

\begin{tabular}{lllllllll}
\hline 0.050 & - & 77.27 & 77.25 & 77.56 & - & 0.0481 & 0.0051 & $0.0045(43)$ \\
0.100 & - & 39.23 & 39.21 & 39.64 & - & 0.0486 & 0.0051 & $0.0028(40)$ \\
0.150 & - & 26.28 & 26.26 & 26.50 & - & 0.0489 & 0.0053 & $0.0052(33)$ \\
0.200 & - & 19.74 & 19.71 & 19.90 & - & 0.0490 & 0.0052 & $0.0032(32)$ \\
0.250 & - & 15.78 & 15.78 & 15.95 & - & 0.0485 & 0.0052 & 0.0022
\end{tabular}

Ave. Dielectric Constant $3.581 \quad 3.588$ 
Table A-1 Continued. Dissipation Factor and Capacitance Measurements of As-Received TCE and TCE Contaminated with Rosin

\begin{tabular}{|c|c|c|c|c|c|c|c|c|}
\hline \multirow{2}{*}{$\begin{array}{l}\text { Gap } \\
\text { Spacing } \\
\text { (Inch) }\end{array}$} & \multicolumn{4}{|c|}{ Capac1tance (pF) } & \multicolumn{4}{|c|}{ Disslpation Factor } \\
\hline & $1 \mathrm{kHz}$ & $10 \mathrm{kHz}$ & $100 \mathrm{kHz}$ & $1 \mathrm{MHz}$ & $1 \mathrm{kHz}$ & $10 \mathrm{kHz}$ & $100 \mathrm{kHz}$ & $1 \mathrm{MHz}$ \\
\hline \multicolumn{9}{|c|}{ Solution: 40 -Percent Rosin from F1ux B (Measured 10-11-88) } \\
\hline $\begin{array}{l}0.050 \\
0.100 \\
0.150 \\
0.200 \\
0.250\end{array}$ & $\begin{array}{l}78.33 \\
39.86 \\
26.72 \\
20.09 \\
16.08\end{array}$ & $\begin{array}{l}78.34 \\
39.86 \\
26.72 \\
20.10 \\
16.07\end{array}$ & $\begin{array}{l}78.30 \\
39.80 \\
26.69 \\
20.06 \\
16.04\end{array}$ & $\begin{array}{l}79.51 \\
40.23 \\
26.89 \\
20.20 \\
16.16\end{array}$ & $\begin{array}{l}0.4955 \\
0.4956 \\
0.4854 \\
0.4949 \\
0.4945\end{array}$ & $\begin{array}{l}0.0501 \\
0.0503 \\
0.0505 \\
0.0506 \\
0.0507\end{array}$ & $\begin{array}{l}0.0057 \\
0.0057 \\
0.0059 \\
0.0059 \\
0.0060\end{array}$ & $\begin{array}{l}0.0041 \\
0.0044 \\
0.0037 \\
0.0037 \\
0.0045\end{array}$ \\
\hline Ave. $D i t$ & electr1 & Constan & 3.640 & 3.640 & & & & \\
\hline
\end{tabular}

Solution: 50--Percent Rosin from Flux A (Measured 10-11-88)

\begin{tabular}{lllllllll}
\hline 0.050 & 78.19 & 78.19 & 78.16 & 79.09 & 0.1270 & 0.0132 & 0.0037 & 0.0224 \\
0.100 & 39.68 & 39.69 & 39.66 & 39.92 & 0.1261 & 0.0131 & 0.0034 & 0.0179 \\
0.150 & 26.56 & 26.58 & 26.56 & 26.74 & 0.1254 & 0.0132 & 0.0035 & 0.0175 \\
0.200 & 19.95 & 19.97 & 19.95 & 20.06 & 0.1249 & 0.0133 & 0.0034 & 0.0170 \\
0.250 & 15.94 & 15.973 & 15.967 & 16.03 & 0.1244 & 0.0126 & 0.0038 & 0.0168
\end{tabular}

Ave. Dielectric Constant $3.613 \quad 3.614$

* Measurements in parentheses were taken at a later date. 
Table A-2. Dissipation Factor and Capacitance Measurements of As-Received TCA and TCA Contaminated With Rosin

\begin{tabular}{|c|c|c|c|c|c|c|c|c|}
\hline \multirow{2}{*}{$\begin{array}{l}\text { Gap } \\
\text { Spacing } \\
\text { (1nch) }\end{array}$} & \multicolumn{4}{|c|}{ Capac1tance $(\mathrm{pF})$} & \multicolumn{4}{|c|}{ Dissipation Factor } \\
\hline & $1 \mathrm{kHz}$ & $10 \mathrm{kHz}$ & $100 \mathrm{kHz}$ & $1 \mathrm{MHz}$ & $1 \mathrm{kHz}$ & $10 \mathrm{kHz}$ & $100 \mathrm{kHz}$ & $1 \mathrm{MHz}$ \\
\hline Solution: & \multicolumn{2}{|c|}{$\begin{array}{l}\text { Atr (Capacitance } \\
11-5-88 \text { ) }\end{array}$} & meast & $10-11$ & & Actos. & tor $m$ & \\
\hline $\begin{array}{l}0.050 \\
0.100 \\
0.150 \\
0.200 \\
0.250\end{array}$ & $\begin{array}{r}21.56 \\
10.95 \\
7.34 \\
5.50 \\
4.39\end{array}$ & $\begin{array}{r}21.58 \\
10.970 \\
7.351 \\
5.518 \\
4.410\end{array}$ & $\begin{array}{l}21.55 \\
10.966 \\
7.344 \\
5.511 \\
4.403\end{array}$ & $\begin{array}{r}21.72 \\
11.049 \\
7.399 \\
5.551 \\
4.435\end{array}$ & $\begin{array}{l}0 \\
0 \\
0 \\
0 \\
0\end{array}$ & $\begin{array}{l}0.0005 \\
0 \\
0.0001 \\
0.0002 \\
0.0002\end{array}$ & $\begin{array}{l}0.0001 \\
0.0003 \\
0.0006 \\
0.0008 \\
0.0012\end{array}$ & $\begin{array}{l}0.0003 \\
0 \\
0 \\
0 \\
0\end{array}$ \\
\hline
\end{tabular}

So1ution: As-Recelved Technical Grade TCA (Measured 10-11-88)

\begin{tabular}{lrrrrrrrr}
\hline 0.050 & - & 155.20 & 155.17 & 158.40 & - & 0.0970 & 0.0118 & 0.0197 \\
0.100 & - & 78.75 & 78.74 & 80.25 & -- & 0.1141 & 0.0117 & 0.0040 \\
0.150 & - & 52.74 & 52.72 & 53.59 & -- & 0.1176 & 0.0123 & 0.0068 \\
0.200 & - & 39.57 & 39.54 & 40.10 & -- & 0.1194 & 0.0121 & 0.0028 \\
0.250 & - & 31.60 & 31.58 & 32.02 & -- & 0.1202 & 0.0121 & 0.0022
\end{tabular}

Ave. Dielectric Constant $\quad 7.184 \quad 7.237$

Solution: As-Recelved Technical Grade TCA (Measured 11-5-88)

\begin{tabular}{lrrrrrrrr}
\hline 0.050 & -- & 155.86 & 155.83 & 160.17 & - & 0.0912 & 0.0091 & 0.0019 \\
0.100 & -- & 79.15 & 79.12 & 80.56 & - & 0.0964 & 0.0096 & 0.0012 \\
0.150 & - & 52.99 & 52.97 & 53.77 & -- & 0.0989 & 0.0098 & 0.0015 \\
0.200 & -- & 39.78 & 39.78 & 40.33 & -- & 0.0989 & 0.0098 & 0.0016 \\
0.250 & -- & 31.77 & 31.76 & 32.18 & -- & 0.0994 & 0.0099 & 0.0015
\end{tabular}

Ave. Dielectric Constant $7.220 \quad 7.270$

Solution: 0.05-Percent Rosin from Flux A (Measured 11-5-88)

\begin{tabular}{lrrrrrrrr}
\hline 0.050 & - & 155.55 & 155.52 & 159.74 & - & 0.1202 & 0.0120 & 0.0021 \\
0.100 & - & 79.11 & 79.08 & 80.52 & - & 0.1223 & 0.0122 & 0.0015 \\
0.150 & - & 52.95 & 52.93 & 53.72 & - & 0.1206 & 0.0122 & 0.0018 \\
0.200 & - & 39.74 & 39.73 & 40.28 & - & 0.1209 & 0.0122 & 0.0018 \\
0.250 & - & 31.75 & 31.72 & 32.15 & - & 0.1215 & 0.0121 & 0.0015
\end{tabular}

Ave. Dielectrt.c Constant $7.213 \quad 7.263$ 
Table A-2 Continued. Dissipation Factor and Capacitance Measurements of As-Received TCA and TCA Contaminated with Rosin

\begin{tabular}{|c|c|c|c|c|c|c|}
\hline \multirow{2}{*}{$\begin{array}{l}\text { Gap } \\
\text { Spacing } \\
\text { (Inch) }\end{array}$} & \multicolumn{2}{|l|}{ Capac1tance $(\mathrm{pF})$} & \multicolumn{4}{|c|}{ D1sstpation Factor } \\
\hline & $10 \mathrm{kHz}$ & $100 \mathrm{kHz}$ & $1 \mathrm{kHz}$ & $10 \mathrm{kHz}$ & $100 \mathrm{kHz}$ & $1 \mathrm{MHz}$ \\
\hline
\end{tabular}

Solution: 0.1-Percent. Rosin from F.1ux A (Measured 11-5-88)

\begin{tabular}{lrrrrrrrr}
\hline 0.050 & - & 155.80 & 155.79 & 160.02 & - & 0.1249 & 0.0125 & 0.0022 \\
0.100 & - & 79.16 & 79.10 & 80.55 & - & 0.1283 & 0.0128 & 0.0015 \\
0.150 & -- & 52.97 & 52.95 & 53.75 & - & 0.1261 & 0.0127 & 0.0019 \\
0.200 & -- & 39.78 & 39.75 & 40.32 & -- & 0.1261 & 0.0126 & 0.0020 \\
0.250 & - & 31.76 & 31.76 & 32.18 & -- & 0.1267 & 0.0127 & 0.0017 \\
Ave. Dielectric Constant & 7.218 & 7.269 & & & & & \\
\hline
\end{tabular}

Solution: 0.5-Percent Rosin from Flux A (Measured 11-5--88)

\begin{tabular}{lrrrrrrrr}
\hline 0.050 & - & 155.25 & 155.23 & 159.39 & $-\cdots$ & 0.2146 & 0.0215 & 0.0032 \\
0.100 & - & 78.94 & 78.89 & 80.36 & -- & 0.2158 & 0.0217 & 0.0028 \\
0.150 & -- & 52.79 & 52.76 & 53.55 & $-\ldots$ & 0.2118 & 0.0213 & 0.0028 \\
0.200 & -- & 39.64 & 39.63 & 40.17 & -- & 0.2098 & 0.0212 & 0.0028 \\
0.250 & - & 31.65 & 31.64 & 32.05 & -- & 0.2096 & 0.0211 & 0.0026 \\
Ave. Dielectr1c Constant & 7.195 & 7.243 & & & & \\
\hline
\end{tabular}

Solution: 1-Percent Rosin from F'lux. A (Measured 11-5-88)

\begin{tabular}{llrrrrrrr}
\hline 0.050 & - & 154.87 & 155.84 & 159.06 & - & 0.3023 & 0.0303 & 0.0041 \\
0.100 & - & 78.54 & 78.51 & 80.03 & - & 0.3000 & 0.0301 & 0.0039 \\
0.150 & -- & 52.59 & 52.58 & 53.41 & -- & 0.2992 & 0.0301 & 0.0040 \\
0.200 & -- & 39.48 & 39.46 & 40.00 & - & 0.2986 & 0.0300 & 0.0035 \\
0.250 & - & 31.55 & 31.52 & 31.93 & -- & 0.2982 & 0.0301 & 0.0043
\end{tabular}

Ave. Dielectric Constant $7.168 \quad 7.203$

Solution: 3-Percent Rosin from Flux A (Measured 11-5-88)

\begin{tabular}{rrrrrrrrr}
\hline 0.050 & - & 154.49 & 152.44 & 156.53 & - & 0.5682 & 0.0570 & 0.0072 \\
0.100 & - & 77.33 & 77.30 & 78.72 & - & 0.5667 & 0.0569 & 0.0067 \\
0.150 & - & 51.79 & 51.75 & 52.58 & - & 0.5661 & 0.0570 & 0.0069 \\
0.200 & - & 38.88 & 38.86 & 39.43 & - & 0.5658 & 0.0568 & 0.0067 \\
0.250 & - & 31.03 & 31.03 & 31.47 & - & 0.5662 & 0.0569 & 0.0066
\end{tabular}

Ave. Dielectric Constant $\quad 7.056 \quad 7.108$ 
Table A-2 Continued. Dissipation Factor and Capacitance Measurements of As-Received TCA and TCA Contaminated with Rosin

\begin{tabular}{|c|c|c|c|c|c|c|c|c|}
\hline \multirow{2}{*}{$\begin{array}{l}\text { Gap } \\
\text { Spacing } \\
\text { (Inch) }\end{array}$} & \multicolumn{4}{|c|}{ Capac1tance (pF) } & \multicolumn{4}{|c|}{ Dissipation Factor } \\
\hline & $1 \mathrm{kHz}$ & $10 \mathrm{kHz}$ & $100 \mathrm{kHz}$ & $1 \mathrm{MHz}$ & $1 \cdot \mathrm{kHz}$ & $10 \mathrm{kHz}$ & $100 \mathrm{kHz}$ & $1 \mathrm{MHz}$ \\
\hline
\end{tabular}

Solution: 5-Percent Rosin from Flux A (Measured 10-11-88)

\begin{tabular}{lrrrrrrrr}
\hline 0.050 & - & 148.79 & 148.76 & 152.79 & - & 0.7006 & 0.0703 & 0.0095 \\
0.100 & - & 75.54 & 75.52 & 76.87 & - & 0.6991 & 0.0694 & 0.0069 \\
0.150 & - & 50.62 & 50.58 & 51.34 & - & 0.6977 & 0.0685 & 0.0055 \\
0.200 & - & 38.00 & 37.97 & 38.50 & - & 0.6970 & 0.0677 & 0.0040 \\
0.250 & - & 30.36 & 30.31 & 30.74 & - & 0.6964 & 0.0673 & 0.0034
\end{tabular}

Ave. Dielectric Constant: $6.894 \quad 6.940$

Solution: 10-Percent Rosin from Flux A (Measured 10-11-88)

\begin{tabular}{lrrrrrrrr}
\hline 0.050 & - & 144.02 & 143.95 & 147.75 & $-\cdots$ & 0.6921 & 0.0670 & 0.0042 \\
0.100 & - & 73.16 & 73.12 & 74.41 & - & 0.6919 & 0.0676 & 0.0056 \\
0.150 & - & 48.99 & 48.94 & 49.67 & $-\cdots$ & 0.6924 & 0.0681 & 0.0063 \\
0.200 & - & 36.79 & 36.75 & 37.25 & $\cdots$ & 0.6936 & 0.0698 & 0.0081 \\
0.250 & - & 29.37 & 29.34 & 29.74 & $\cdots$ & 0.6949 & 0.0698 & 0.0094
\end{tabular}

Ave. Dielectric Constant $\quad 6.673 \quad 6.716$

Solution: 15-Percent Rosin from Flux A (Measured 10-11-88)

\begin{tabular}{llrrrrrrr}
\hline 0.050 & - & 138.47 & 138.33 & 141.84 & - & 0.6714 & 0.0677 & 0.0093 \\
0.100 & - & 70.44 & 70.33 & 71.53 & - & 0.6704 & 0.0667 & 0.0072 \\
0.150 & - & 47.18 & 47.09 & 47.77 & - & 0.6696 & 0.0657 & 0.0056 \\
0.200 & - & 35.40 & 35.35 & 35.81 & - & 0.6694 & 0.0654 & 0.0060 \\
0.250 & - & 28.32 & 28.26 & 28.62 & -- & 0.6687 & 0.0650 & 0.0061
\end{tabular}

Ave. Dielectric Constant $6.421 \quad 6.459$

Solution: 20-Percent Rosin from Flux A (Measured 10-11-88)

\begin{tabular}{lrrrrrrrr}
\hline 0.050 & - & 137.40 & 137.29 & 140.74 & - & 0.7617 & 0.0766 & 0.0095 \\
0.100 & - & 69.56 & 69.50 & 70.65 & - & 0.7609 & 0.0757 & 0.0075 \\
0.150 & - & 46.65 & 46.60 & 47.25 & - & 0.7602 & 0.0749 & 0.0064 \\
0.200 & - & 35.04 & 34.97 & 35.43 & $\cdots$ & 0.7598 & 0.0744 & 0.0050 \\
0.250 & - & 28.01 & 27.97 & 28.30 & $\cdots$ & 0.7596 & 0.0739 & 0.0044
\end{tabular}

Ave. Dielectric Constant $\quad 6.356 \quad 6.386$ 
Table A-2 Continued. Dissipation Factor and Capacitance

Measurements of As-Received TCA and TCA Contaminated with Rosin

\begin{tabular}{lllllll}
\hline $\begin{array}{l}\text { Gap } \\
\begin{array}{l}\text { Spacing } \\
\text { Inch) }\end{array}\end{array}$ & \multicolumn{3}{l}{ Capac1tance (pF) } & \multicolumn{3}{l}{ Dissipation Factor } \\
\hline
\end{tabular}

Solution: 25-Percent Rosin from Flux B (Measured 10-11-88)

\begin{tabular}{lllrrrrrr}
\hline 0.050 & - & 130.89 & 130.89 & 133.82 & - & 0.6218 & 0.0633 & 0.0143 \\
0.100 & - & 66.31 & 66.20 & 67.26 & - & 0.6216 & 0.0624 & 0.0122 \\
0.150 & - & 44.4744 & 44.38 & 44.98 & - & 0.6211 & 0.0618 & 0.0099 \\
0.200 & - & 33.38 & 33.31 & 33.74 & - & 0.6214 & 0.0612 & 0.0082 \\
0.250 & - & 26.70 & 26.65 & 26.97 & - & 0.6214 & 0.0601 & 0.0036
\end{tabular}

Ave. Dielectric Constant $\quad 6.056 \quad 6.082$

Solution: 30-Percent Rosin from Flux B (Measured 10-11-88)

\begin{tabular}{lrrrrrrrr}
\hline 0.050 & - & 126.12 & 125.98 & 128.95 & - & 0.3725 & 0.0376 & 0.0073 \\
0.100 & - & 64.15 & 64.08 & 65.09 & - & 0.3710 & 0.0365 & 0.0041 \\
0.150 & - & 42.99 & 42.94 & 43.51 & - & 0.3703 & 0.0357 & 0.0031 \\
0.200 & - & 32.26 & 32.22 & 32.60 & - & 0.3702 & 0.0353 & 0.0022 \\
0.250 & - & 25.79 & 25.75 & 26.05 & - & 0.3701 & 0.0350 & 0.0015
\end{tabular}

Ave. Dlelectrlc Constant $\quad 5.851 \quad 5.880$

Solution: 30-Percent Rosin from Flux A (Measured 10-11-88)

\begin{tabular}{lrrrrrrrr}
\hline 0.050 & - & 124.64 & 124.50 & 127.43 & - & 0.3705 & 0.0373 & 0.0066 \\
0.100 & - & 63.31 & 63.23 & 64.21 & - & 0.3698 & 0.0361 & 0.0043 \\
0.1 .50 & - & 42.43 & 42.36 & 42.92 & - & 0.3700 & 0.0353 & 0.0031 \\
0.200 & - & 31.84 & 31.78 & 32.16 & - & 0.3710 & 0.0351 & 0.0022 \\
0.250 & - & 25.43 & 25.38 & 25.70 & - & 0.3730 & 0.0347 & 0.0009
\end{tabular}

Ave. Dielectric Constant $\quad 5.774 \quad 5.800$

Solution: 40-Percent Rosin from Flux B (Measured 11-5-88)

\begin{tabular}{lrrrrrrrr}
\hline 0.050 & - & 119.29 & 119.13 & 121.68 & - & 0.2224 & 0.0241 & 0.0187 \\
0.100 & - & 60.66 & 60.58 & 61.04 & - & 0.2233 & 0.0304 & 0.0710 \\
0.150 & - & 40.64 & 40.57 & 40.82 & - & 0.2232 & 0.0298 & 0.0720 \\
0.200 & - & 30.52 & 30.46 & 30.56 & - & 0.2235 & 0.0315 & 0.0725 \\
0.250 & - & 24.40 & 24.35 & 24.51 & - & 0.2236 & 0.0279 & 0.0580
\end{tabular}

Ave. Dielectric Constant. $\quad 5.533 \quad 5.518$ 
Table A-2 Continued. Dissipation Factor and Capacitance Measurements of As-Received TCA and TCA Contaminated with Rosin

\begin{tabular}{|c|c|c|c|c|c|c|c|c|}
\hline \multirow{2}{*}{$\begin{array}{l}\text { Gap } \\
\text { Spac1ng } \\
\text { (1nch) }\end{array}$} & \multicolumn{4}{|c|}{ Capac1tance $(\mathrm{pF})$} & \multicolumn{4}{|c|}{ Dissipation Factor } \\
\hline & $1 \mathrm{kHz}$ & $10 \mathrm{kHz}$ & $100 \mathrm{kHz}$ & $1 \mathrm{MHz}$ & $1 \mathrm{kHz}$ & $10 \mathrm{kHz}$ & $100 \mathrm{kHz}$ & $1 \mathrm{MḦ̈z}$ \\
\hline \multicolumn{9}{|c|}{ Solution: 50-Percent Rosin from Flux A (Measured 11-5-88) } \\
\hline $\begin{array}{l}0.050 \\
0.100 \\
0.150 \\
0.200 \\
0.250\end{array}$ & $\begin{array}{r}102.50 \\
52.02 \\
34.84 \\
26.15 \\
20.88\end{array}$ & $\begin{array}{r}102.50 \\
52.04 \\
34.84 \\
26.16 \\
20.90\end{array}$ & $\begin{array}{r}102.20 \\
51.88 \\
34.73 \\
26.06 \\
20.82\end{array}$ & $\begin{array}{r}102.12 \\
51.53 \\
34.43 \\
25.85 \\
20.64\end{array}$ & $\begin{array}{l}0.0777 \\
0.0785 \\
0.0782 \\
0.0780 \\
0.0780\end{array}$ & $\begin{array}{l}0.0089 \\
0.0090 \\
0.0091 \\
0.0093 \\
0.0094\end{array}$ & $\begin{array}{l}0.0084 \\
0.0083 \\
0.0083 \\
0.0083 \\
0.0083\end{array}$ & $\begin{array}{l}0.0284 \\
0.0264 \\
0.0260 \\
0.0265 \\
0.0270\end{array}$ \\
\hline \multicolumn{3}{|c|}{ Ave. Dlelectric Constant } & 4.743 & 4.657 & & & & \\
\hline
\end{tabular}


Table A-3. Dissipation Factor and Capacitance Measurements of Solutions With Unknown Contamination Type

\begin{tabular}{|c|c|c|c|c|c|c|c|c|}
\hline \multirow{2}{*}{$\begin{array}{l}\text { Gap } \\
\text { Spac1ng } \\
\text { (1nch) }\end{array}$} & \multicolumn{4}{|c|}{ Capac1tance ( $\mathrm{pF}$ ) } & \multicolumn{4}{|c|}{ DLssipation Factor } \\
\hline & $1 \mathrm{kHz}$ & $10 \mathrm{kHz}$ & $100 \mathrm{kHz}$ & $1 \mathrm{MHz}$ & $1 \mathrm{kHz}$ & $10 \mathrm{kHz}$ & $100 \mathrm{kHz}$ & $1 \mathrm{MHz}$ \\
\hline \multicolumn{5}{|c|}{$\begin{array}{l}\text { Solution Source: Spray Booth } \\
\text { Suspected Major Contamination: Rosin } \\
\text { Nonvolatile Contamination: } 0.32 \% \text { by Welght }\end{array}$} & \multicolumn{4}{|c|}{$\begin{array}{l}\text { Solvent: TCE } \\
\text { Sample collected on 10-27-88 } \\
\text { Measured on 11-5-88 }\end{array}$} \\
\hline $\begin{array}{l}0.050 \\
0.100 \\
0.150 \\
0.200 \\
0.250\end{array}$ & $\begin{array}{c}-- \\
-\infty \\
-- \\
--\end{array}$ & $\begin{array}{l}73.68 \\
37.45 \\
25.10 \\
18.86 \\
15.062\end{array}$ & $\begin{array}{l}73.64 \\
37.42 \\
25.07 \\
18.83 \\
15.069\end{array}$ & $\begin{array}{l}74.76 \\
37.81 \\
25.30 \\
19.00 \\
15.218\end{array}$ & $\begin{array}{c}-\cdots \\
-\cdots \\
-\cdots \\
-\infty\end{array}$ & $\begin{array}{l}0.1340 \\
0.1357 \\
0.1368 \\
0.1373 \\
0.1368\end{array}$ & $\begin{array}{l}0.0134 \\
0.0136 \\
0.0139 \\
0.0140 \\
0.0139\end{array}$ & $\begin{array}{l}0.0018 \\
0.0018 \\
0.0017 \\
0.0018 \\
0.0012\end{array}$ \\
\hline
\end{tabular}

Ave. Dlelectric Constant $3.418 \quad 3.428$

Solution Source: Vapor Degreaser

Suspected Major Contamination: 011

Nonvolatile Contanination: $0.15 \%$ by Wedght Meag
Solvent: TCA

Sample collected on $11-5-88$
Measured on $11-5-88$

\begin{tabular}{rrrrrrrrr}
\hline 0.050 & - & 141.53 & 141.14 & 144.67 & - & 0.5430 & 0.0550 & 0.0062 \\
0.100 & - & 71.89 & 71.73 & 72.99 & - & 0.5436 & 0.0549 & 0.0061 \\
0.150 & - & 48.12 & 48.01 & 48.73 & - & 0.5409 & 0.0547 & 0.0064 \\
0.200 & - & 36.13 & 36.04 & 36.55 & $-\cdots$ & 0.5375 & 0.0544 & 0.0061 \\
0.250 & - & 28.84 & 28.79 & 29.14 & $-\cdots$ & 0.5362 & 0.0540 & 0.0052
\end{tabular}

Ave. Dielectric Constant $6.549 \quad 6.602$

Solution Source: Spray Booth

Suspected Major Contamination: Rosin

Nonvolatile Contamination: $3.6 \%$ by Welght

Note: There was a large amount of alcohol floating on the TCE in the waste contalner.

\begin{tabular}{lllllllll}
\hline 0.050 & - & - & 77.66 & 78.85 & - & - & 0.0941 & 0.0107 \\
0.100 & - & - & 39.43 & 39.87 & - & - & 0.0943 & 0.0109 \\
0.150 & - & - & 26.41 & 26.68 & $-\cdots$ & - & 0.0944 & 0.0111 \\
0.200 & - & - & 19.82 & 20.00 & $\cdots$ & $\cdots$ & 0.0944 & 0.0104 \\
0.250 & $\cdots$ & $-\cdots$ & 15.857 & 15.98 & $\cdots$ & $-\cdots$ & 0.0943 & 0.0107
\end{tabular}

Ave. Dlelectric Constant. $3.418 \quad 3.428$ 
Table A-3 Continued. Dissipation Factor and Capacitance Measurements of Solutions With Unknown Contamination Type

\begin{tabular}{|c|c|c|c|c|c|c|c|c|}
\hline \multirow{2}{*}{$\begin{array}{l}\text { Gap } \\
\text { Spacing } \\
\text { (Inch) }\end{array}$} & \multicolumn{4}{|c|}{ Capacitance (pF) } & \multicolumn{4}{|c|}{ DLsaLpation Factor } \\
\hline & $1 \mathrm{kHz}$ & $10 \mathrm{kHz}$ & $100 \mathrm{kHz}$ & $1 \mathrm{MHZz}$ & $1 \mathrm{kHHz}$ & $10 \mathrm{kHz}$ & $100 \mathrm{kHz}$ & $1 \mathrm{MHz}$ \\
\hline \multicolumn{5}{|c|}{$\begin{array}{l}\text { Solution Source: Vapor Degreaser } \\
\text { Suspected Major Contamination: 0.1s } \\
\text { Nonvolatile Contamination: } 0.1 \% \text { by Welght }\end{array}$} & \multicolumn{4}{|c|}{$\begin{array}{l}\text { Solvent: TCA } \\
\text { Samp.le collected on 10-27-88 } \\
\text { Measured on } 11-5-88\end{array}$} \\
\hline $\begin{array}{l}0.050 \\
0.100 \\
0.150 \\
0.200 \\
0.250\end{array}$ & $\begin{array}{l}74.18 \\
37.70 \\
25.25 \\
18.97 \\
15.15\end{array}$ & $\begin{array}{l}74.21 \\
37.72 \\
25.28 \\
18.98 \\
15.184\end{array}$ & $\begin{array}{l}74.19 \\
37.71 \\
25.27 \\
18.97 \\
15.180\end{array}$ & $\begin{array}{l}75.36 \\
38.14 \\
25.51 \\
19.14 \\
15.336\end{array}$ & $\begin{array}{l}0.0686 \\
0.0684 \\
0.0682 \\
0.0682 \\
0.0680\end{array}$ & $\begin{array}{l}0.0070 \\
0.0072 \\
0.0073 \\
0.0074 \\
0.0068\end{array}$ & $\begin{array}{l}0.0007 \\
0.0009 \\
0.0009 \\
0.0008 \\
0.0010\end{array}$ & $\begin{array}{l}0.0006 \\
0.0005 \\
0.0004 \\
0.0005 \\
0.0000\end{array}$ \\
\hline Ave. $D 1$ & electric & Constant & 6.5485 & 6.602 & & & & \\
\hline \multicolumn{5}{|c|}{$\begin{array}{l}\text { Solution Source: Vapor Degreager } \\
\text { Suspected Major Contamination: } 18 \\
\text { Nonvolatile Contamination: } 0.5 \% \text { by Welght }\end{array}$} & \multicolumn{4}{|c|}{$\begin{array}{l}\text { Solvent: TCE } \\
\text { Sample collected on } 10-30-88 \\
\text { Measured on } 11-5-88\end{array}$} \\
\hline $\begin{array}{l}0.050 \\
0.100 \\
0.150 \\
0.200 \\
0.250\end{array}$ & $\begin{array}{l}73.39 \\
37.34 \\
24.98 \\
18.76 \\
15.00\end{array}$ & $\begin{array}{l}73.43 \\
37.36 \\
25.00 \\
18.78 \\
15.027\end{array}$ & $\begin{array}{l}73.41 \\
37.34 \\
24.99 \\
18.76 \\
15.025\end{array}$ & $\begin{array}{l}74.53 \\
37.75 \\
25.23 \\
18.93 \\
15.175\end{array}$ & $\begin{array}{l}0.1796 \\
0.1791 \\
0.1786 \\
0.1784 \\
0.1783\end{array}$ & $\begin{array}{l}0.0182 \\
0.0183 \\
0.0183 \\
0.0185 \\
0.0178\end{array}$ & $\begin{array}{l}0.0019 \\
0.0020 \\
0.0020 \\
0.0020 \\
0.0021\end{array}$ & $\begin{array}{l}0.0008 \\
0.0008 \\
0.0006 \\
0.0006 \\
0.0001\end{array}$ \\
\hline Ave. Dite & electrlo & Constant & 3.406 & 3.418 & & & & \\
\hline
\end{tabular}


Append $1 \times$ B

BOILING POINT MEASUREMENTS

OF AS-RECEIVED AND ROSIN-

CONTAMINATED TRI CHLOROETHYLENE

AND $1,1,1-T R I$ CHLOROETHANE 
MATERIALIS AND PROCEDURE

This work was accomplitshed during september and October 1988, with supplemental laboratory tests in January 1989.

\section{SOLVENTS AND ROSIN}

The trichloroethylene (TCE) used in all the laboratory experiments was from one 5 -galion can of technical grade solvent. The trichloroethane (TCA) used in ald the laboratory experiments was from one lot of technical grade solvent supplied in l-gallon glass containers.

The rosin used as contamination in the experiments was taken from two solder fluxes which meet MIL-F-14256 specification as types $R$ and RMA. The rosin solvent carrier (alcohol) in the flux was removed by elevating the flux temperature to 80 to $90^{\circ} \mathrm{C}$ for 16 to 48 hours $\left(90^{\circ} \mathrm{C}\right.$ is well below the boiling point of the flux and $\operatorname{rosin)}$.

\section{BOILING POINT MEASUREMENTS}

For the purposes of this report, the boiling point is either the measured temperature of the vapor zone as stated in ASTM D 1078-86, "Distillation Range of Volatile organic Liquids," or the measured temperature in the vapor zone or in the solution for some other described laboratory setup.

Initially, boiling point temperature measurements were made of the as-received and rosin-contaminated solvents according to ASTM D 1078. ASTM D 1078 requires that the mercury measuring

thermometer be placed only in th. $a$ vapor zone above the boiling solution and not in the solution. Measurements of the boliling point of as-recelved TCE and TCit according to ASTM D 1078 were made and are found in Tables B-I and B-2. The ASTM D 1078 method gave inconsistent results for rosin-contaminated solutions. The ASTM D 1078 procedure is designed for measuring the distiliation range of volatile organic liquids, that is, pure chemicals, and has severe limitations if applied to contaminated solutions. To measure the boiling point of contaminated solutions, the temperature probe must be in the solution, not above it as is the common laboratory practice for pure chemicals.

A modified ASTM method was used to measure the boiling points of the contaminated solutions and is shown as Figure il in the main body of this report. As the solution is distilled, the contamination level of the solution increases. The contamination level at any polnt can be calculated from the known amount of rosin in solution, the initial amount of solvent in the flask, and the amount of solvent distilled. The following equation was used to calculate the contamination percent by weight. 
$W \%=\frac{W r}{(V t s-V d s) s g+W r}=\frac{1}{\left[(V t s-1.5-V d s) \frac{s g}{W r}\right]+1}$,

where wr is the rosin weight, vts is the total volume of the initial amount of pure solvent, vas is the amount of distilled solvent, $1.5 \mathrm{~mL}$ of solvent is estimated to be condensed on the surfaces of the glass ware, and $\mathrm{Sg}$ is the specific gravity of the pure solvent. Vds and $\mathrm{Sg}$ are measured values. Wr and $\mathrm{Vts}$ can be calculated by knowing the specific gravity of a solution as some weight percent ( $W \%$ ) of rosin contamination by the following equation. The total volume of contaminated solvent is $250 \mathrm{~mL}$ in this example.

$W_{t}=[250 \mathrm{~mL}] \mathrm{Sg}(5 \%)$,

$=356.13 \mathrm{~g}$;

Wr $=0.05 \mathrm{Wt}$,

$=17.806 \mathrm{~g} ;$ and

$V t s=\frac{W t-W r}{S g(O q)}$,

$=233.0 \mathrm{~mL}$.

The temperature was measured with a thermocouple in the solution as the solvent was being distilied. The thermocouple was $120 \mathrm{~mm}$ lower than the mercury thermometer and at about the $50-\mathrm{mI}$ of solution level. The data in all the tables (B-1 through B-8) have been corrected to $760 \mathrm{~min} \mathrm{Hg}$ pressure. In Tables B-4 through $B-7$, the boiling point temperature change caused by contamination was calculated by substracting the boiling point of as-received solvent from the bolling point of contaminated solvent for the same amount of distilied solvent. 
Table B-1. Boiling Point Measurements of As-Received and Rosin-Contaminated TCE According to ASTM D 1078 (100-mL Sollition)

Solution Bolling Point $\left({ }^{\circ} \mathrm{C}\right)$

\begin{tabular}{|c|c|c|c|c|c|c|c|c|c|}
\hline \multirow{2}{*}{$\begin{array}{l}\text { Amount } \\
\text { Dist1lled } \\
\text { (mI) }\end{array}$} & \multicolumn{2}{|c|}{ As-Recelved TCE } & \multicolumn{7}{|c|}{ Rosin in TCE (percent by weight) } \\
\hline & Test 1 & Test 2 & $\begin{array}{l}5 \# \\
A^{*}\end{array}$ & $\begin{array}{l}10^{*} \\
A^{\star}\end{array}$ & $\begin{array}{l}15 \\
A^{*}\end{array}$ & $\begin{array}{l}20 \\
B *\end{array}$ & $\begin{array}{l}25 \\
B *\end{array}$ & $\begin{array}{l}30 \\
\mathrm{~B} *\end{array}$ & $\begin{array}{l}30 \text { 非 } \\
\mathrm{A}^{*}\end{array}$ \\
\hline $\begin{array}{l}\text { First Drop } \\
5 \\
10 \\
20 \\
30\end{array}$ & $\begin{array}{l}86.6 \\
86.8 \\
86.8 \\
86.9 \\
86.9\end{array}$ & $\begin{array}{l}86.4 \\
86.7 \\
86.8 \\
86.8 \\
86.9\end{array}$ & $\begin{array}{l}85.6 \\
86.3 \\
86.4 \\
86.7 \\
86.8\end{array}$ & $\begin{array}{l}84.7 \\
86.1 \\
86.4 \\
86.5 \\
86.8\end{array}$ & $\begin{array}{l}84.0 \\
85.6 \\
86.0 \\
86.3 \\
86.6\end{array}$ & $\begin{array}{l}84.5 \\
85.6 \\
86.0 \\
86.4 \\
86.6\end{array}$ & $\begin{array}{l}84.2 \\
85.6 \\
86.1 \\
86.4 \\
86.6\end{array}$ & $\begin{array}{l}84.5 \\
85.5 \\
86.0 \\
86.3 \\
86.5\end{array}$ & $\begin{array}{l}81.5 \\
84.5 \\
84.9 \\
86.1 \\
86.6\end{array}$ \\
\hline $\begin{array}{l}40 \\
50 \\
60 \\
70 \\
80\end{array}$ & $\begin{array}{l}86.9 \\
87.0 \\
87.1 \\
87.1 \\
87.1\end{array}$ & $\begin{array}{l}86.9 \\
86.9 \\
86.9 \\
87.0 \\
87.0\end{array}$ & $\begin{array}{l}86.9 \\
86.9 \\
87.0 \\
87.0 \\
87.1\end{array}$ & $\begin{array}{l}86.8 \\
86.9 \\
87.0 \\
87.2 \\
87.6\end{array}$ & $\begin{array}{l}86.8 \\
87.0 \\
37.0 \\
87.4 \\
-\end{array}$ & $\begin{array}{l}86.6 \\
86.8 \\
87.2 \\
92.3 \\
-\end{array}$ & $\begin{array}{l}87.1 \\
87.2 \\
94.0 \\
96.0 \\
-\end{array}$ & $\begin{array}{l}87.7 \\
92.5 \\
95.5 \\
-- \\
--\end{array}$ & $\begin{array}{l}87.0 \\
87.9 \\
89.6 \\
-- \\
--\end{array}$ \\
\hline $\begin{array}{l}90 \\
95 \\
\text { Dry }\end{array}$ & $\begin{array}{l}87.2 \\
87.6 \\
87.6\end{array}$ & $\begin{array}{l}87.1 \\
87.2 \\
87.4\end{array}$ & $\begin{array}{l}87.9 \\
90.8 \\
--\end{array}$ & $\begin{array}{l}90.0 \\
--\end{array}$ & $\begin{array}{l}- \\
--\end{array}$ & $\overline{-}$ & $\overline{--}$ & $\begin{array}{l}-- \\
--\end{array}$ & $\begin{array}{l}-- \\
-- \\
--\end{array}$ \\
\hline $\begin{array}{l}\text { Solvent } \\
\text { Recovered } \\
\text { (mL) }\end{array}$ & 98.5 & 98.5 & & & & & & & \\
\hline
\end{tabular}

\#Average of two measurements.

*Indicates rosin source, types $A$ and $B$ solder flux. 
Table B-2. Boiling Foint Measurements of As-Received and Rosin-Contaminated TCA According to ASTM D 1078 (100-mL Solution)

Solution Bolling Point $\left({ }^{\circ} \mathrm{C}\right)$

\begin{tabular}{|c|c|c|c|c|c|c|c|c|c|}
\hline \multirow{2}{*}{$\begin{array}{l}\text { Amount } \\
\text { Distilied } \\
\text { (mL) }\end{array}$} & \multicolumn{2}{|c|}{ As-Recelved TCA } & \multicolumn{7}{|c|}{ Rosin in TCA (percent by weight) } \\
\hline & Test 1 & Test 2 & $\begin{array}{l}5 \# \\
A^{*}\end{array}$ & $\begin{array}{l}10 \# \\
A^{*}\end{array}$ & $\begin{array}{l}15 \\
A^{*}\end{array}$ & $\begin{array}{l}20 \\
A^{*}\end{array}$ & $\begin{array}{l}25 \\
B *\end{array}$ & $\begin{array}{l}30 \\
\mathrm{~B} *\end{array}$ & $\begin{array}{l}30 \text { 非 } \\
A^{*}\end{array}$ \\
\hline $\begin{array}{l}\text { First Drop } \\
5 \\
10 \\
20 \\
30\end{array}$ & $\begin{array}{l}73.5 \\
73.8 \\
73.8 \\
74.0 \\
74.0\end{array}$ & $\begin{array}{l}73.5 \\
73.8 \\
73.9 \\
74.0 \\
74.0\end{array}$ & $\begin{array}{l}72.9 \\
73.4 \\
73.7 \\
73.9 \\
74.0\end{array}$ & $\begin{array}{l}72.2 \\
73.3 \\
73.7 \\
73.8 \\
74.0\end{array}$ & $\begin{array}{l}72.1 \\
73.1 \\
73.3 \\
73.6 \\
73.8\end{array}$ & $\begin{array}{l}72.8 \\
73.4 \\
73.6 \\
73.9 \\
74.0\end{array}$ & $\begin{array}{l}84.2 \\
75.6 \\
76.1 \\
76.4 \\
76.6\end{array}$ & $\begin{array}{l}84.2 \\
75.5 \\
76.0 \\
76.4 \\
76.6\end{array}$ & $\begin{array}{l}71.4 \\
72.5 \\
72.9 \\
73.2 \\
73.5\end{array}$ \\
\hline $\begin{array}{l}40 \\
50 \\
60 \\
70 \\
80\end{array}$ & $\begin{array}{l}74.1 \\
74.2 \\
74.3 \\
74.5 \\
74.7\end{array}$ & $\begin{array}{l}74.1 \\
74.2 \\
74.3 \\
74.4 \\
74.6\end{array}$ & $\begin{array}{l}74.1 \\
74.2 \\
74.3 \\
74.5 \\
74.8\end{array}$ & $\begin{array}{l}74.1 \\
74.2 \\
74.4 \\
74.7 \\
75.6\end{array}$ & $\begin{array}{l}74.0 \\
74.1 \\
74.4 \\
75.1 \\
80.0\end{array}$ & $\begin{array}{l}74.2 \\
74.4 \\
74.8 \\
76.6 \\
-\end{array}$ & $\begin{array}{l}77.1 \\
77.2 \\
94.0 \\
96.0 \\
-\end{array}$ & $\begin{array}{l}77.7 \\
91.5 \\
93.9 \\
-- \\
--\end{array}$ & $\begin{array}{l}74.1 \\
75.3 \\
83.7 \\
-- \\
--\end{array}$ \\
\hline $\begin{array}{l}90 \\
95 \\
\text { Dry }\end{array}$ & $\begin{array}{l}75.3 \\
78.5 \\
98.5\end{array}$ & $\begin{array}{l}75.2 \\
76.1 \\
78.8\end{array}$ & $\begin{array}{l}77.0 \\
-- \\
--\end{array}$ & $\overline{-}$ & $\begin{array}{l}-- \\
--\end{array}$ & - & $\overline{-}$ & - & $\begin{array}{l}-- \\
-- \\
--\end{array}$ \\
\hline $\begin{array}{l}\text { Solvent } \\
\text { Recovered } \\
\text { (mL) }\end{array}$ & 98.5 & 98.5 & & & & & & & \\
\hline
\end{tabular}

\#Average of two measurements.

*Indicates rosin source, Types A and B solder flux. 
Table B-3. Boiling Point Measurements of As-Received TCE and TCA Using $250 \mathrm{~mL}$ of Solution

\begin{tabular}{|c|c|c|}
\hline \multirow{2}{*}{$\begin{array}{l}\text { Amount } \\
\text { Distilled } \\
(m L)\end{array}$} & \multicolumn{2}{|c|}{ Boiling Point $\left({ }^{\circ} \mathrm{C}\right)$} \\
\hline & $\begin{array}{l}\text { TCE } \\
\text { In Vapor }\end{array}$ & $\begin{array}{l}\text { TCA } \\
\text { In Vapor }\end{array}$ \\
\hline $\begin{array}{l}\text { First Drop } \\
5 \\
10 \\
15 \\
20\end{array}$ & $\begin{array}{l}85.7 \\
86.6 \\
86.7 \\
86.7 \\
86.8\end{array}$ & \begin{tabular}{l}
73.6 \\
\hdashline--9 \\
73.9 \\
73.9 \\
73.9
\end{tabular} \\
\hline $\begin{array}{l}25 \\
30 \\
35 \\
40 \\
45\end{array}$ & $\begin{array}{l}86.8 \\
86.8 \\
86.8 \\
86.8 \\
86.8\end{array}$ & $\begin{array}{l}74.0 \\
74.0 \\
74.0 \\
74.0 \\
74.0\end{array}$ \\
\hline $\begin{array}{l}50 \\
55 \\
60 \\
65 \\
70\end{array}$ & $\begin{array}{l}86.8 \\
86.8 \\
86.8 \\
86.8 \\
86.9\end{array}$ & $\begin{array}{l}74.1 \\
74.1 \\
74.1 \\
74.1 \\
74.1\end{array}$ \\
\hline $\begin{array}{l}75 \\
80 \\
85 \\
90 \\
95\end{array}$ & $\begin{array}{l}86.9 \\
86.9 \\
86.9 \\
86.9 \\
86.9\end{array}$ & $\begin{array}{l}74.1 \\
74.1 \\
74.1 \\
74.1 \\
74.1\end{array}$ \\
\hline $\begin{array}{l}100 \\
105 \\
110 \\
115 \\
120\end{array}$ & $\begin{array}{l}86.9 \\
86.9 \\
86.9 \\
86.9 \\
86.9\end{array}$ & $\begin{array}{l}74.1 \\
74.2 \\
74.2 \\
74.2 \\
74.2\end{array}$ \\
\hline $\begin{array}{l}125 \\
130 \\
135 \\
140 \\
145\end{array}$ & $\begin{array}{l}86.9 \\
87.0 \\
87.0 \\
87.0 \\
87.0\end{array}$ & $\begin{array}{l}74.2 \\
74.2 \\
74.2 \\
74.2 \\
74.2\end{array}$ \\
\hline $\begin{array}{l}150 \\
155 \\
160 \\
165 \\
170\end{array}$ & $\begin{array}{l}87.0 \\
87.0 \\
87.0 \\
87.0 \\
87.0\end{array}$ & $\begin{array}{l}74.3 \\
74.3 \\
74.4 \\
74.4 \\
74.4\end{array}$ \\
\hline
\end{tabular}


Table B-3 Continued. Boiling Point Measurements of As-Received TCE and TCA Using $250 \mathrm{~mL}$ of Solution

\begin{tabular}{lll}
\hline & \multicolumn{2}{l}{ Boiling Point $\left({ }^{\circ} \mathrm{C}\right)$} \\
\cline { 2 - 3 } $\begin{array}{ll}\text { Amount } \\
\text { Distilied }\end{array}$ & TCE & TCA \\
\hline 175 & 87.0 & In Vapor \\
180 & 87.0 & 74.5 \\
185 & 87.0 & 74.5 \\
190 & 87.1 & 74.5 \\
195 & 87.1 & 74.6 \\
200 & 87.1 & 74.6 \\
210 & 87.1 & 74.6 \\
220 & 87.1 & 74.8 \\
230 & 87.1 & 75.0 \\
240 & 87.2 & 75.3 \\
245 & 87.3 & 76.3 \\
\hline Dry Point & 87.6 &.--- \\
Solvent Recovered & 247 & 79.1 \\
(mL) & & 247 \\
\hline
\end{tabular}


Table B-4. Boiling Point Measurements of As-Received and Rosin-Contaminated TCE With the Thermometer in the Vapor zone (250-mL Solution)

\begin{tabular}{|c|c|c|c|c|c|c|}
\hline \multirow{2}{*}{$\begin{array}{l}\text { Amount } \\
\text { Dist111ed (mL) }\end{array}$} & \multirow{2}{*}{$\begin{array}{l}\text { Temp. in } \\
\text { As-Recelved } \\
\text { Solvent ( (C) }\end{array}$} & \multicolumn{2}{|c|}{$\begin{array}{l}\text { Temp. In } \\
\text { Contaminated } \\
\text { Solvent ( (C) }\end{array}$} & \multicolumn{2}{|c|}{$\begin{array}{l}\text { Temp. Change } \\
\text { Caused by } \\
\text { Contamination ( }(C)\end{array}$} & \multirow{2}{*}{$\begin{array}{l}\text { Contamination } \\
\text { Level (percent } \\
\text { by welght) }\end{array}$} \\
\hline & & $A^{\star}$ & $B^{\star}$ & $A^{*}$ & $B^{*}$ & \\
\hline Flrst Drop & 85.7 & 85.8 & 85.6 & 0.1 & -0.1 & 5.00 \\
\hline 5 & 86.6 & 86.3 & 86.3 & -0.3 & -0.3 & 5.14 \\
\hline 10 & 86.7 & 86.3 & 86.5 & -0.4 & -0.2 & 5.25 \\
\hline 15 & 86.7 & 86.4 & 86.5 & -0.3 & .0 .2 & 5.36 \\
\hline 20 & 86.8 & 86.5 & 86.6 & -0.3 & -0.2 & 5.48 \\
\hline 25 & 86.8 & 86.5 & 86.6 & -0.3 & -0.2 & 5.61 \\
\hline 30 & 86.8 & 86.5 & 86.6 & -0.3 & -0.2 & 5.74 \\
\hline 35 & 86.8 & 86.6 & 86.7 & -0.2 & -0.1 & 5.87 \\
\hline 40 & 86.8 & 86.6 & 86.7 & -0.2 & -0.1 & 6.00 \\
\hline 45 & 86.8 & 86.7 & 86.7 & -0.1 & -0.1 & 6.17 \\
\hline 50 & 86.8 & 86.7 & 86.7 & -0.1 & -0.1 & 6.35 \\
\hline 55 & 86.8 & 86.7 & 86.7 & -0.1 & .0 .1 & 6.50 \\
\hline 60 & 86.8 & 86.8 & 86.7 & 0.0 & -0.1 & 6.67 \\
\hline 65 & 86.8 & 86.8 & 86.7 & 0.0 & -0.1 & 6.86 \\
\hline 70 & 86.9 & 86.8 & 86.8 & -0.1 & -0.1 & 7.06 \\
\hline 75 & 86.9 & 86.8 & 86.8 & -0.1 & -0.1 & 7.29 \\
\hline 80 & 86.9 & 86.8 & 86.8 & -0.1 & -0.1 & 7.49 \\
\hline 85 & 86.9 & 86.9 & 86.8 & 0.0 & -0.1 & 7.72 \\
\hline 90 & 86.9 & 86.9 & 86.8 & 0.0 & -0.1 & 7.98 \\
\hline 95 & 86.9 & 86.9 & 86.8 & 0.0 & -0.1 & 8.24 \\
\hline 100 & 86.9 & 86.9 & 86.8 & 0.0 & -0.1 & 8.53 \\
\hline 105 & 86.9 & 86.9 & 86.9 & 0.0 & 0.0 & 8.84 \\
\hline 110 & 86.9 & 86.9 & 86.9 & 0.0 & 0.0 & 9.17 \\
\hline 115 & 86.9 & 86.9 & 86.9 & 0.0 & 0.0 & 9.52 \\
\hline 120 & 86.9 & 86.9 & 86.9 & 0.0 & 0.0 & 9.91 \\
\hline 125 & 86.9 & 86.9 & 86.9 & 0.0 & 0.0 & 10.33 \\
\hline 130 & 87.0 & 86.9 & 86.9 & -0.1 & -0.1 & 10.78 \\
\hline 135 & 87.0 & 86.9 & 86.9 & -0.1 & -0.1 & 11.28 \\
\hline 140 & 87.0 & 86.9 & 86.9 & -0.1 & -0.1 & 11.82 \\
\hline 145 & 87.0 & 87.0 & 86.9 & 0.0 & -0.1 & 12.42 \\
\hline 150 & 87.0 & 87.0 & 86.9 & 0.0 & -0.1 & 13.08 \\
\hline 155 & 87.0 & 87.0 & 86.9 & 0.0 & -0.1 & 13.82 \\
\hline 160 & 87.0 & 87.0 & 86.9 & 0.0 & -0.1 & 14.64 \\
\hline 165 & 87.0 & 87.0 & 86.9 & 0.0 & -0.1 & 15.57 \\
\hline 170 & 87.0 & 87.0 & 86.9 & 0.0 & -0.1 & 16.63 \\
\hline
\end{tabular}


Table B-4 Continued. Boiling Point Measurements of

As-Received and Rosin-Contaminated TCE With the Thermometer in the Vapor Zone

(250-mL Solution)

\begin{tabular}{|c|c|c|c|c|c|c|}
\hline \multirow{2}{*}{$\begin{array}{l}\text { Amount } \\
\text { Dist1lled (mL) }\end{array}$} & \multirow{2}{*}{$\begin{array}{l}\text { Temp. In } \\
\text { As-Recel ved } \\
\text { Solvent ( (C) }\end{array}$} & \multicolumn{2}{|c|}{$\begin{array}{l}\text { Temp. 1n } \\
\text { Contaminated } \\
\text { Solvent ( }(C)\end{array}$} & \multicolumn{2}{|c|}{$\begin{array}{l}\text { Temp. Change } \\
\text { Caused by } \\
\text { Contamination ( (C) }\end{array}$} & \multirow{2}{*}{$\begin{array}{l}\text { Contamination } \\
\text { Level (Percent } \\
\text { by Weight) }\end{array}$} \\
\hline & & $A^{\star}$ & $B^{*}$ & $A^{*}$ & $B^{\star}$ & \\
\hline 175 & 87.0 & 87.0 & 87.0 & 0.0 & 0.0 & 17.83 \\
\hline 180 & 87.0 & 87.1 & 87.0 & 0.1 & 0.0 & 19.23 \\
\hline 185 & 87.0 & 87.1 & 87.0 & 0.1 & 0.0 & 20.87 \\
\hline 190 & 87.1 & 87.1 & 87.0 & 0.0 & 0.0 & 22.81 \\
\hline 195 & 87.1 & 87.1 & 87.0 & 0.0 & 0.0 & 25.15 \\
\hline 200 & 87.1 & 87.1 & 87.0 & 0.0 & 0.0 & 28.02 \\
\hline 205 & 87.1 & --- & --- & $-\cdots$ & $\cdots$ & $-\cdots$ \\
\hline 210 & 87.1 & 87.1 & 87.1 & 0.0 & 0.0 & 36.32 \\
\hline 215 & 87.2 & --- & --- & $\cdots$ & --- & --- \\
\hline 220 & 87.3 & 87.3 & 87.3 & --- & $-\cdots$ & 51.60 \\
\hline 225 & $\cdots$ & $\cdots$ & 87.5 & $\cdots$ & $\cdots$ & 65.36 \\
\hline 228 & -.- & 87.5 & $\cdots$ & $-\cdots$ & $\cdots$ & 77.80 \\
\hline 230 & 87.6 & $\cdots$ & 87.9 & $\cdots$ & -- & 89.10 \\
\hline
\end{tabular}

* $A$ and $B$ denotes the flux from which the rosin was obtained. 
Table B-5. Boiling Point Measurements of As-Received and Rosin-Contaminated TCE With the Thermometer in the Solution (250-mL Solution)

\begin{tabular}{|c|c|c|c|c|c|c|}
\hline \multirow{2}{*}{$\begin{array}{l}\text { Amount } \\
\text { D1st111ed (mL) }\end{array}$} & \multirow{2}{*}{$\begin{array}{l}\text { Temp. in } \\
\text { As-Recelved } \\
\text { Solvent ( }(C)\end{array}$} & \multicolumn{2}{|c|}{$\begin{array}{l}\text { Temp. In } \\
\text { Contaminated } \\
\text { Solvent ( }(C)\end{array}$} & \multicolumn{2}{|c|}{$\begin{array}{l}\text { Temp. Change } \\
\text { Caused by } \\
\text { Contamination ( (C) }\end{array}$} & \multirow{2}{*}{$\begin{array}{l}\text { Contamination } \\
\text { level (percent } \\
\text { by welght) }\end{array}$} \\
\hline & & $A^{\star}$ & $B^{\star}$ & $A^{\star}$ & $B^{\star}$ & \\
\hline F1rst Drop & 87.6 & 87.8 & 87.9 & 0.2 & 0.3 & 5.00 \\
\hline 5 & 87.8 & 87.9 & 88.0 & 0.1 & 0.2 & 5.14 \\
\hline 10 & 87.9 & 88.1 & 88.4 & 0.2 & 0.2 & 5.25 \\
\hline 15 & 87.8 & 88.2 & 88.4 & 0.4 & 0.6 & 5.36 \\
\hline 20 & 87.9 & 88.2 & 88.6 & 0.3 & 0.7 & 5.48 \\
\hline 25 & 87.9 & 88.2 & 88.6 & 0.3 & 0.7 & 5.61 \\
\hline 30 & 87.9 & 88.3 & 88.6 & 0.4 & 0.7 & 5.74 \\
\hline 35 & 88.0 & 88.4 & 88.6 & 0.4 & 0.6 & 5.87 \\
\hline 40 & 88.0 & 88.4 & 88.6 & 0.4 & 0.6 & 6.02 \\
\hline 45 & 88.0 & 88.5 & 88.7 & 0.5 & 0.7 & 6.17 \\
\hline 50 & 88.0 & 88.5 & 88.7 & 0.5 & 0.7 & 6.35 \\
\hline 55 & 88.0 & 88.5 & 88.7 & 0.5 & 0.7 & 6.50 \\
\hline 60 & 88.0 & 88.5 & 88.8 & 0.5 & 0.8 & 6.67 \\
\hline 65 & 88.0 & 88.6 & 88.9 & 0.6 & 0.9 & 6.86 \\
\hline 70 & 88.0 & 88.8 & 88.9 & 0.8 & 0.9 & 7.06 \\
\hline 75 & 88.0 & 88.8 & 88.9 & 0.8 & 0.9 & 7.29 \\
\hline 80 & 88.0 & 88.8 & 89.0 & 0.8 & 1.0 & 7.49 \\
\hline 85 & 88.0 & 88.8 & 89.0 & 0.8 & 1.0 & 7.72 \\
\hline 90 & 88.1 & 89.0 & 89.0 & 0.9 & 0.9 & 7.98 \\
\hline 95 & 88.2 & 89.0 & 89.1 & 0.8 & 0.9 & 8.24 \\
\hline 100 & 88.1 & 89.1 & 89.1 & 1.0 & 1.0 & 8.53 \\
\hline 105 & 88.2 & 89.1 & 89.1 & 1.1 & 0.9 & 8.84 \\
\hline 110 & 88.0 & 89.2 & 89.2 & 1.2 & 1.2 & 9.17 \\
\hline 115 & 88.1 & 89.1 & 89.4 & 1.0 & 1.3 & 9.52 \\
\hline 120 & 88.0 & 89.2 & 89.3 & 1.2 & 1.3 & 9.91 \\
\hline 125 & 88.1 & 89.2 & 89.5 & 1.1 & 1.4 & 10.33 \\
\hline 130 & 88.0 & 89.3 & 89.5 & 1.3 & 1.5 & 10.78 \\
\hline 135 & 88.0 & 89.4 & 89.4 & $1 \ldots 4$ & 1.4 & 11.28 \\
\hline
\end{tabular}

*A and $B$ denotes the flux from which the rosin was obtalned. 
Table B-6. Boiling Point Measurements of As-Received and Rosin-Contaminated TCA with the Thermometer in the Vapor Zone (250-mL Solution)

\begin{tabular}{|c|c|c|c|c|c|c|}
\hline \multirow{2}{*}{$\begin{array}{l}\text { Amount } \\
\text { Distllled (mL) }\end{array}$} & \multirow{2}{*}{$\begin{array}{l}\text { Temp. In } \\
\text { As-Recelved } \\
\text { Solvent (IC) }\end{array}$} & \multicolumn{2}{|c|}{$\begin{array}{l}\text { Temp, in } \\
\text { Contaminated } \\
\text { Solvent (IC) }\end{array}$} & \multicolumn{2}{|c|}{$\begin{array}{l}\text { T'emp. Change } \\
\text { Caused by } \\
\text { Contamination ( }(C)\end{array}$} & \multirow{2}{*}{$\begin{array}{l}\text { Contamtration } \\
\text { Level (percent } \\
\text { by weight) }\end{array}$} \\
\hline & & $A^{\star}$ & $B^{*}$ & $A^{*}$ & $B^{\star}$ & \\
\hline FIrst Drop & 73.6 & 73.1 & 73.3 & -0.5 & -0.3 & 5.0 \\
\hline 5 &.-- & 73.4 & 73.6 & 0.0 & $-\cdots$ & 5.14 \\
\hline 10 & 73.9 & 73.7 & 73.8 & -0.2 & -0.1 & 5.24 \\
\hline 15 & 73.9 & 73.8 & 73.9 & -0.1 & 0.0 & 5.36 \\
\hline 20 & 73.9 & 73.8 & 73.9 & -0.1 & 0.0 & 5.48 \\
\hline 25 & 74.0 & 73.8 & 74.0 & -0.2 & 0.0 & 5.60 \\
\hline 30 & 74.0 & 73.9 & 74.0 & -0.1 & 0.0 & 5.73 \\
\hline 35 & 74.0 & 73.9 & 74.1 & -0.1 & 0.1 & 5.87 \\
\hline 40 & 74.0 & 74.0 & 74.1 & 0.0 & 0.1 & 6.01 \\
\hline 45 & 74.0 & 74.0 & 74.1 & 0.0 & 0.1 & 6.16 \\
\hline 50 & 74.1 & 74.0 & 74.1 & -0.1 & 0.0 & 6.32 \\
\hline 55 & 74.1 & 74.0 & 74.1 & -0.1 & 0.0 & 6.48 \\
\hline 60 & 74.1 & 74.1 & 74.1 & 0.0 & 0.0 & 6.66 \\
\hline 65 & 74.1 & 74.1 & 74.1 & 0.0 & 0.0 & 6.84 \\
\hline 70 & 74.1 & 74.1 & 74.1 & 0.0 & 0.0 & 7.04 \\
\hline 75 & 74.1 & 74.1 & 74.1 & 0.0 & 0.0 & 7.24 \\
\hline 80 & 74.1 & 74.1 & 74.2 & 0.0 & 0.1 & 7.46 \\
\hline 85 & 74.1 & 74.1 & 74.2 & 0.0 & 0.1 & 7.69 \\
\hline 90 & 74.1 & 74.1 & 74.2 & 0.0 & 0.1 & 7.94 \\
\hline 95 & 74.1 & 74.2 & 74.2 & 0.1 & 0.1 & 8.21 \\
\hline 100 & 74.1 & 74.2 & 74.2 & 0.1 & 0.1 & 8.49 \\
\hline 105 & 74.2 & 74.2 & 74.2 & 0.0 & 0.0 & 8.79 \\
\hline 110 & 74.2 & 74.2 & 74.3 & 0.0 & 0.1 & 9.11 \\
\hline 115 & 74.2 & 74.2 & 74.3 & 0.0 & 0.1 & 9.46 \\
\hline 120 & 74.2 & 74.3 & 74.3 & 0.1 & 0.1 & 9.84 \\
\hline 125 & 74.2 & 74.3 & 74.3 & 0.1 & 0.1 & 10.25 \\
\hline 130 & 74.2 & 74.3 & 74.3 & 0.1 & 0.1 & 10.69 \\
\hline 135 & 74.2 & 74.3 & 74.3 & 0.1 & 0.1 & 11.18 \\
\hline 140 & 74.2 & 74.4 & 74.3 & 0.2 & 0.1 & 11.71 \\
\hline 145 & 74.2 & 74.4 & 74.4 & 0.2 & 0.2 & 12.29 \\
\hline 150 & 74.3 & 74.4 & 74.4 & 0.1 & 0.1 & 12.93 \\
\hline 155 & 74.3 & 74.5 & 74.4 & 0.2 & 0.1 & 13.65 \\
\hline 160 & 74.4 & 74.5 & 74.5 & 0.1 & 0.1 & 14.44 \\
\hline 165 & 74.4 & 74.5 & 74.5 & 0.1 & 0.1 & 15.34 \\
\hline 170 & 74.4 & 74.6 & 74.6 & 0.2 & 0.2 & 16.36 \\
\hline
\end{tabular}


Table B-6 Continued. Boiling Point Measurements of

As-Recelved and Rosin-Contaminated TCA With the Thermometer in the Vapor zone

(250-mL solution)

\begin{tabular}{|c|c|c|c|c|c|c|}
\hline \multirow{2}{*}{$\begin{array}{l}\text { Amount } \\
\text { Dist1llad (ml.) }\end{array}$} & \multirow{2}{*}{$\begin{array}{l}\text { Temp. In } \\
\text { As-Recelved } \\
\text { Solvent ([C) }\end{array}$} & \multicolumn{2}{|c|}{$\begin{array}{l}\text { Temp. In } \\
\text { Contaminated } \\
\text { solvent ( (C) }\end{array}$} & \multicolumn{2}{|c|}{$\begin{array}{l}\text { Temp. Change } \\
\text { Caused by } \\
\text { contamtnation (IC) }\end{array}$} & \multirow{2}{*}{$\begin{array}{l}\text { Contaminlation } \\
\text { Level (percent } \\
\text { by weight) }\end{array}$} \\
\hline & & $A^{*}$ & $B^{\star}$ & $A^{\star}$ & B* & \\
\hline 175 & 74.5 & 74.6 & 74.6 & 0.1 & 0.1 & 17.52 \\
\hline 180 & 74.5 & 74.7 & 74.6 & 0.2 & 0.1 & 18.85 \\
\hline 185 & 74.5 & 74.7 & 74.6 & 0.2 & 0.1 & 20.41 \\
\hline 190 & 74.6 & 74.8 & 74.7 & 0.2 & 0.1 & 22.25 \\
\hline 195 & 74.6 & 74.8 & 74.7 & 0.2 & 0.1 & 24.45 \\
\hline 200 & 74.6 & 74.9 & 74.9 & 0.3 & 0.3 & 27.14 \\
\hline 210 & 74.8 & 75.2 & 75.2 & 0.4 & 0.4 & 34.78 \\
\hline 220 & 75.0 & 75.8 & 76.0 & 0.8 & 1.0 & 48.41 \\
\hline 228 & $-\cdots$ & 77.1 & $\cdots$ & 1.8 & $\cdots$ & 70.53 \\
\hline 230 & 75.3 & $\cdots$ & 78.4 & -.. & 3.1 & 79.63 \\
\hline 240 & 76.3 & $\ldots$ & $\cdots$ & $\cdots$ &.-- & $\cdots$ \\
\hline 247 (Dry Polnt) & 79.1 & $\cdots$ & -- & $\cdots$ & $\cdots$ & $\cdots$ \\
\hline
\end{tabular}

${ }^{*} A_{1}$ and $B$ denote the flux from which the rosin was obtained. 
Table B-7. Boiling Point Measurements of As-Received and Rosin-Contaminated TCA With the Thermometer in the Solution (250-mL Solution)

\begin{tabular}{|c|c|c|c|c|c|c|}
\hline \multirow{2}{*}{$\begin{array}{l}\text { Amount } \\
\text { Dist11led (mL) }\end{array}$} & \multirow{2}{*}{$\begin{array}{l}\text { Temp. In } \\
\text { As } \sim \text { Recutved } \\
\text { Solvent ([C) }\end{array}$} & \multicolumn{2}{|c|}{$\begin{array}{l}\text { Tomp. in } \\
\text { Contaminated } \\
\text { Solvent ( }(C)\end{array}$} & \multicolumn{2}{|c|}{$\begin{array}{l}\text { Temp, Change } \\
\text { Caused by } \\
\text { Contamtnation (lC) }\end{array}$} & \multirow{2}{*}{$\begin{array}{l}\text { Contamination } \\
\text { Level (Percent } \\
\text { by Welght) }\end{array}$} \\
\hline & & $A^{*}$ & $B^{\star}$ & $A^{*}$ & $B *$ & \\
\hline F1rst Drop & 74.6 & 74.6 & 74.6 & 0.0 & 0.0 & 5.0 \\
\hline 5 & 74.6 & 74.8 & 74.9 & 0.2 & 0.3 & 5.1 \\
\hline 10 & 74.8 & 75.0 & 75.0 & 0.2 & 0.2 & 5.2 \\
\hline 15 & 74.8 & 75.1 & 75.2 & 0.3 & 0.4 & 5.3 \\
\hline 20 & 74.8 & 75.2 & 75.3 & 0.4 & 0.5 & 5.4 \\
\hline 25 & 75.0 & 75.1 & 75.4 & 0.1 & 0.4 & 5.6 \\
\hline 30 & 74.9 & 75.3 & 75.3 & 0.4 & 0.4 & 5.7 \\
\hline 35 & 74.9 & 75.3 & 75.4 & 0.4 & 0.5 & 5.8 \\
\hline 40 & 74.9 & 75.3 & 75.5 & 0.4 & 0.6 & 6.0 \\
\hline 45 & 74.9 & 75.4 & 75.5 & 0.5 & 0.6 & 6.1 \\
\hline 50 & 74.9 & 75.4 & 75.5 & 0.5 & 0.6 & 6.3 \\
\hline 55 & 75.1 & 75.5 & 75.5 & 0.4 & 0.4 & 6.4 \\
\hline 60 & 75.1 & 75.5 & 75.6 & 0.4 & 0.5 & 6.6 \\
\hline 65 & 75.1 & 75.5 & 75.7 & 0.4 & 0.6 & 6.8 \\
\hline 70 & 75.0 & 75.4 & 75.7 & 0.4 & 0.7 & 7.0 \\
\hline 75 & 75.1 & 75.6 & 75.8 & 0.5 & 0.7 & 7.2 \\
\hline 80 & 75.1 & 75.6 & 75.8 & 0.5 & 0.7 & 7.4 \\
\hline 85 & 75.2 & 75.7 & 75.9 & 0.5 & 0.7 & 7.6 \\
\hline 90 & 75.1 & 75.7 & 76.0 & 0.6 & 0.8 & 7.9 \\
\hline 95 & 75.2 & 75.8 & 76.0 & 0.6 & 0.8 & 8.1 \\
\hline 100 & 75.2 & 75.8 & 76.1 & 0.6 & 0.9 & 8.4 \\
\hline 105 & 75.2 & 75.9 & 76.1 & 0.7 & 0.9 & 8.7 \\
\hline 110 & 75.2 & 76.0 & 76.1 & 0.8 & 0.9 & 9.0 \\
\hline 115 & 75.3 & 76.1 & 76.2 & 0.8 & 0.9 & 9.4 \\
\hline 120 & 75.4 & 76.1 & 76.2 & 0.7 & 0.8 & 9.7 \\
\hline 125 & 75.3 & 76.2 & 76.4 & 0.9 & 1.1 & 10.1 \\
\hline 130 & 75.3 & 76.3 & 76.4 & 1.0 & 1.1 & 10.6 \\
\hline 135 & 75.4 & 76.3 & 76.5 & 0.9 & 1.1 & 11.0 \\
\hline 140 & 75.4 & 76.3 & 76.5 & 0.9 & 1.1 & 11.5 \\
\hline
\end{tabular}

* $A$ and $B$ denote the flux from which the rosin was ontalned. 
Table B-8. Bolling Point Measurements of Solventis with

Unknown Contamination From Various Manufacturing Departments

\begin{tabular}{|c|c|c|c|c|c|c|}
\hline \multirow{3}{*}{$\begin{array}{l}\text { Amount } \\
\text { Distilied } \\
(m L)\end{array}$} & \multicolumn{6}{|c|}{$\begin{array}{l}\text { Solution Bolling Point* }\left({ }^{\circ} \mathrm{C}\right) \text { Related to Solvent } \\
\text { Manufacturing Department Source }\end{array}$} \\
\hline & \multicolumn{2}{|c|}{ Timer Assembly } & \multicolumn{2}{|c|}{ Multiwire Cables } & \multicolumn{2}{|c|}{ Wlectronic Assembly } \\
\hline & $\mathbf{s}$ & $V$ & $\mathbf{S}$ & V & $\mathbf{S}$ & $\mathrm{V}$ \\
\hline $\begin{array}{l}\text { First Drop } \\
10 \\
20 \\
30 \\
40\end{array}$ & $\begin{array}{l}76.9 \\
77.9 \\
78.0 \\
78.0 \\
78.1\end{array}$ & $\begin{array}{l}74.8 \\
76.5 \\
76.7 \\
76.7 \\
76.7\end{array}$ & $\begin{array}{l}87.7 \\
87.8 \\
87.7 \\
87.8 \\
87.9\end{array}$ & $\begin{array}{l}86.5 \\
87.0 \\
87.1 \\
87.1 \\
87.2\end{array}$ & $\begin{array}{l}76.4 \\
.78 .8 \\
80.5 \\
81.7 \\
82.3\end{array}$ & $\begin{array}{l}69.3 \\
75.1 \\
77.2 \\
80.1 \\
80.9\end{array}$ \\
\hline $\begin{array}{l}50 \\
60 \\
70 \\
80 \\
90\end{array}$ & $\begin{array}{l}78.1 \\
78.2 \\
78.3 \\
78.5 \\
78.6\end{array}$ & $\begin{array}{l}76.7 \\
76.9 \\
77.0 \\
76.9 \\
76.8\end{array}$ & $\begin{array}{l}87.9 \\
87.8 \\
87.8 \\
87.9 \\
87.9\end{array}$ & $\begin{array}{l}87.2 \\
87.2 \\
87.2 \\
87.2 \\
87.2\end{array}$ & $\begin{array}{l}82.8 \\
83.0 \\
83.4 \\
83.7 \\
83.9\end{array}$ & $\begin{array}{l}81.0 \\
81.8 \\
82.2 \\
82.4 \\
82.7\end{array}$ \\
\hline $\begin{array}{l}100 \\
110 \\
120 \\
130 \\
140\end{array}$ & $\begin{array}{l}78.7 \\
78.6 \\
78.8 \\
79.0 \\
79.1\end{array}$ & $\begin{array}{l}76.8 \\
77.0 \\
77.1 \\
77.0 \\
77.1\end{array}$ & $\begin{array}{l}87.9 \\
87.9 \\
87.9 \\
87.9 \\
87.9\end{array}$ & $\begin{array}{l}87.2 \\
87.2 \\
87.2 \\
87.2 \\
87.2\end{array}$ & $\begin{array}{l}84.3 \\
84.4 \\
84.8 \\
85.1 \\
85.4\end{array}$ & $\begin{array}{l}83.1 \\
83.4 \\
83.5 \\
84.1 \\
84.3\end{array}$ \\
\hline $\begin{array}{l}150 \\
160 \\
170 \\
180 \\
190\end{array}$ & $\begin{array}{l}79.2 \\
79.3 \\
79.6 \\
79.7 \\
79.8\end{array}$ & $\begin{array}{l}77.1 \\
77.1 \\
77.3 \\
77.3 \\
77.5\end{array}$ & $\begin{array}{l}87.9 \\
87.9 \\
88.0 \\
87.9 \\
87.9\end{array}$ & $\begin{array}{l}87.2 \\
87.2 \\
87.2 \\
87.2 \\
87.2\end{array}$ & $\begin{array}{l}85.6 \\
85.9 \\
86.1 \\
86.3 \\
86.6\end{array}$ & $\begin{array}{l}84.5 \\
84.8 \\
85.1 \\
85.2 \\
85.5\end{array}$ \\
\hline $\begin{array}{l}200 \\
210 \\
220 \\
230 \\
240\end{array}$ & $\begin{array}{l}80.0 \\
80.1 \\
80.4 \\
80.6 \\
80.8\end{array}$ & $\begin{array}{l}77.6 \\
77.6 \\
77.8 \\
77.9 \\
77.8\end{array}$ & $\begin{array}{l}87.9 \\
87.9 \\
87.9 \\
87.9 \\
87.9\end{array}$ & $\begin{array}{l}87.2 \\
87.2 \\
87.2 \\
87.2 \\
87.2\end{array}$ & $\begin{array}{l}86.7 \\
86.8 \\
87.1 \\
87.2 \\
87.3\end{array}$ & $\begin{array}{l}85.7 \\
86.0 \\
86.1 \\
86.2 \\
86.4\end{array}$ \\
\hline $\begin{array}{l}250 \\
\text { Nonvolatile** } \\
\text { ( } 8 \text { by Weight) }\end{array}$ & $\begin{array}{r}81.2 \\
2.1\end{array}$ & $\begin{array}{r}78.2 \\
\text { to } 4.2\end{array}$ & $\begin{array}{r}87.9 \\
0.32\end{array}$ & $\begin{array}{ll} & 87.2 \\
\text { t.o } \quad 0.65\end{array}$ & $\begin{array}{r}87.4 \\
0.41\end{array}$ & to 86.5 \\
\hline \multicolumn{7}{|c|}{$\begin{array}{l}\text { Key: } \\
\text { S denotes temperature measured in the solution, and } V \text { denc } \\
\text { temperature measured in the vapor zone. } \\
\text { * } 250 \mathrm{~mL} \text { of solvent were distilled from } 500 \mathrm{~mL} \text { in a } 1000-n \\
\text { flask. } \\
\text { \#\# Measurements of a sample taken in December } 1988 \text {. } \\
\text { * The two values are the initial and final concentrations } \\
\text { nonvolatile residue in the bolitng flask. }\end{array}$} \\
\hline
\end{tabular}


Table B-8 Continued. Bolling Point Measurements of Solvents With Unknown Contamination From Varlous Manufacturing Departments

\begin{tabular}{|c|c|c|c|c|c|c|}
\hline \multirow{3}{*}{$\begin{array}{l}\text { Amount } \\
\text { Disti11ed } \\
(m L)\end{array}$} & \multicolumn{6}{|c|}{$\begin{array}{l}\text { Solution Bolling Polnt* }\left({ }^{\circ} \mathrm{C}\right) \text { Related to Solvent } \\
\text { Manufacturing Department. Source }\end{array}$} \\
\hline & \multicolumn{2}{|c|}{ PWB Fabrication } & \multicolumn{2}{|c|}{$\begin{array}{l}\text { Electrical } \\
\text { Assembly }\end{array}$} & \multicolumn{2}{|c|}{$\begin{array}{l}\text { Plating and } \\
\text { Chem MIII }\end{array}$} \\
\hline & $\mathbf{S}$ & V & $\mathbf{s}$ & $\mathrm{V}$ & $\mathbf{S}$ & V \\
\hline $\begin{array}{l}\text { First Drop } \\
10 \\
20 \\
30 \\
40\end{array}$ & $\begin{array}{l}76.2 \\
76.3 \\
76.4 \\
76.5\end{array}$ & $\begin{array}{l}74.9 \\
75.6 \\
75.8 \\
75.8 \\
--\end{array}$ & $\begin{array}{l}86.7 \\
87.2 \\
87.4 \\
87.7 \\
87.8\end{array}$ & $\begin{array}{l}84.6 \\
85.7 \\
86.2 \\
86.5 \\
86.6\end{array}$ & $\begin{array}{l}87.9 \\
88.1 \\
88.1 \\
88.1 \\
88.1\end{array}$ & $\begin{array}{l}87.0 \\
87.2 \\
87.2 \\
87.3 \\
87.3\end{array}$ \\
\hline $\begin{array}{l}50 \\
60 \\
70 \\
80 \\
90\end{array}$ & $\begin{array}{l}-\overline{76} \\
76.6 \\
-\overline{76.6}\end{array}$ & $\begin{array}{l}75.9 \\
76.0 \\
7 \overline{76.1}\end{array}$ & $\begin{array}{l}87.9 \\
88.1 \\
88.1 \\
88.2 \\
88.2\end{array}$ & $\begin{array}{l}86.7 \\
86.9 \\
87.0 \\
87.0 \\
87.1\end{array}$ & $\begin{array}{l}88.1 \\
88.1 \\
88.1 \\
88.1 \\
88.1\end{array}$ & $\begin{array}{l}87.3 \\
87.3 \\
87.3 \\
87.3 \\
87.3\end{array}$ \\
\hline $\begin{array}{l}100 \\
110 \\
120 \\
130 \\
140\end{array}$ & $\begin{array}{l}-- \\
76.7 \\
-- \\
--\end{array}$ & $\begin{array}{l}m-1 \\
-16.1 \\
-- \\
--\end{array}$ & $\begin{array}{l}88.3 \\
88.4 \\
88.4 \\
88.4 \\
88.5\end{array}$ & $\begin{array}{l}87.1 \\
87.1 \\
87.1 \\
87.1 \\
87.2\end{array}$ & $\begin{array}{l}88.1 \\
88.1 \\
88.1 \\
88.1 \\
88.1\end{array}$ & $\begin{array}{l}87.3 \\
87.3 \\
87.3 \\
87.3 \\
87.3\end{array}$ \\
\hline $\begin{array}{l}150 \\
160 \\
170 \\
180 \\
190\end{array}$ & $\begin{array}{l}76.8 \\
77.0 \\
-77.0 \\
77.1\end{array}$ & $\begin{array}{l}76.2 \\
76.3 \\
-76.3 \\
76.3\end{array}$ & $\begin{array}{l}88.5 \\
88.5 \\
88.6 \\
88.6 \\
88.6\end{array}$ & $\begin{array}{l}87.2 \\
87.2 \\
87.2 \\
87.2 \\
87.2\end{array}$ & $\begin{array}{l}88.1 \\
88.1 \\
88.1 \\
88.1 \\
88.2\end{array}$ & $\begin{array}{l}87.3 \\
87.3 \\
87.3 \\
87.3 \\
87.4\end{array}$ \\
\hline $\begin{array}{l}200 \\
210 \\
220 \\
230 \\
240\end{array}$ & $\begin{array}{l}-7 \\
77.2 \\
77.3 \\
77.4 \\
77.5\end{array}$ & $\begin{array}{l}7 \overline{76} .5 \\
76.5 \\
76.5 \\
76.7\end{array}$ & $\begin{array}{l}88.8 \\
88.8 \\
89.0 \\
88.8 \\
89.0\end{array}$ & $\begin{array}{l}87.2 \\
87.2 \\
87.2 \\
87.2 \\
87.2\end{array}$ & $\begin{array}{l}88.1 \\
88.2 \\
88.2 \\
88.2 \\
88.2\end{array}$ & $\begin{array}{l}87.4 \\
87.4 \\
87.4 \\
87.4 \\
87.4\end{array}$ \\
\hline $\begin{array}{l}250 \\
\text { Nonvolatile* } \\
(q \text { by Weight) }\end{array}$ & $\begin{array}{l}77.5 \\
0.15\end{array}$ & to $\quad 0.30$ & $\begin{array}{r}89.1 \\
3.6\end{array}$ & $\begin{array}{r}87.2 \\
\text { to } 7.2\end{array}$ & $\begin{array}{r}88.2 \\
0.09\end{array}$ & to 87.4 \\
\hline \multicolumn{7}{|c|}{$\begin{array}{l}\text { Key: } \\
\mathbf{s} \text { denotes temperature measured in the solution, and } v \text { denote } \\
\text { temperature measured in the vapor zone. } \\
\text { * } 250 \text { mL of solvent were distilied from } 500 \mathrm{~mL} \text { in a } 1000 \mathrm{~mL} \\
\text { flask. } \\
\text { \# Measurements of a sample taken in October } 1986 \text {. } \\
\text { * The two values are the initial and final concentrations of } \\
\text { nonvolatile residue in the boiling flask. }\end{array}$} \\
\hline
\end{tabular}


Table B-8 Continued. Boling point Measurements of Solvents With Unknown Contamination From Varlous Manufacturing Departments

\begin{tabular}{|c|c|c|c|c|c|c|}
\hline \multirow{3}{*}{$\begin{array}{l}\text { Amount } \\
\text { Distilied } \\
(m L)\end{array}$} & \multicolumn{6}{|c|}{$\begin{array}{l}\text { Solution Bolling Point* }\left({ }^{\circ} \mathrm{C}\right) \text { Related to } \\
\text { Solvent Manufacturing Department Source }\end{array}$} \\
\hline & \multicolumn{3}{|c|}{ Heat Treating } & \multicolumn{3}{|c|}{ Heat Treating } \\
\hline & $\mathbf{S}$ & & V & $\mathbf{S}$ & & V \\
\hline $\begin{array}{l}\text { First Drop } \\
10 \\
20 \\
30 \\
40\end{array}$ & $\begin{array}{l}88.0 \\
88.1 \\
88.2 \\
88.3 \\
88.3\end{array}$ & & $\begin{array}{l}86.8 \\
87.0 \\
87.1 \\
87.1 \\
87.2\end{array}$ & $\begin{array}{l}88.5 \\
88.7 \\
88.8 \\
88.8 \\
88.7\end{array}$ & & $\begin{array}{l}86.9 \\
87.1 \\
87.2 \\
87.2 \\
87.2\end{array}$ \\
\hline $\begin{array}{l}50 \\
60 \\
70 \\
80 \\
90\end{array}$ & $\begin{array}{l}88.3 \\
88.4 \\
88.4 \\
88.4 \\
88.5\end{array}$ & & $\begin{array}{l}87.2 \\
87.2 \\
87.2 \\
87.2 \\
87.2\end{array}$ & $\begin{array}{l}88.8 \\
88.9 \\
88.9 \\
88.9 \\
89.0\end{array}$ & & $\begin{array}{l}87 \cdot 3 \\
87 \cdot 3 \\
87 \cdot 3 \\
87 \cdot 3 \\
87 \cdot 3\end{array}$ \\
\hline $\begin{array}{l}100 \\
110 \\
120 \\
130 \\
140\end{array}$ & $\begin{array}{l}88.5 \\
88.5 \\
88.6 \\
88.6 \\
88.6\end{array}$ & & $\begin{array}{l}87.2 \\
87.2 \\
87.2 \\
87.2 \\
87.2\end{array}$ & $\begin{array}{l}89.0 \\
88.9 \\
89.1 \\
89.1 \\
89.1\end{array}$ & & $\begin{array}{l}87.3 \\
87.3 \\
87.3 \\
87.3 \\
87.3\end{array}$ \\
\hline $\begin{array}{l}150 \\
160 \\
170 \\
180 \\
190\end{array}$ & $\begin{array}{l}88.6 \\
88.6 \\
88.6 \\
88.7 \\
88.8\end{array}$ & & $\begin{array}{l}87.2 \\
87.2 \\
87.2 \\
87.2 \\
87.2\end{array}$ & $\begin{array}{l}89.3 \\
89.3 \\
89.4 \\
89.4 \\
89.4\end{array}$ & & $\begin{array}{l}87 \cdot 3 \\
87 \cdot 3 \\
87 \cdot 3 \\
87 \cdot 3 \\
87.3\end{array}$ \\
\hline $\begin{array}{l}200 \\
210 \\
220 \\
230 \\
240\end{array}$ & $\begin{array}{l}88.8 \\
88.8 \\
88.9 \\
88.9 \\
89.0\end{array}$ & & $\begin{array}{l}87 \cdot 2 \\
87 \cdot 3 \\
87 \cdot 3 \\
87 \cdot 3 \\
87.3\end{array}$ & $\begin{array}{l}89.6 \\
89.5 \\
89.6 \\
89.7 \\
89.9\end{array}$ & & $\begin{array}{l}87 \cdot 3 \\
87 \cdot 3 \\
87.3 \\
87.3 \\
87.3\end{array}$ \\
\hline $\begin{array}{l}250 \\
\text { Nonvolatile** } \\
(q \text { by Weight) }\end{array}$ & $\begin{array}{r}89.0 \\
0.5\end{array}$ & to & $\begin{array}{r}87.3 \\
1.0\end{array}$ & $\begin{array}{r}89.9 \\
1.4\end{array}$ & to & $\begin{array}{r}87.3 \\
2.9\end{array}$ \\
\hline
\end{tabular}

Key:

$S$ denotes temperature measured in the solution, and $V$ denotes temperature measured in the vapor zone.

* $250 \mathrm{~mL}$ of solvent were distilled from $500 \mathrm{~mL}$ in a $1000-\mathrm{mL}$ flask.

\# Measurements of a sample taken in October 1988.

\#\# Measurements of a sample taken in December 1988.

$\star *$ The two values are the initial and final concentrations of norvolatile residue in the boliling flask. 

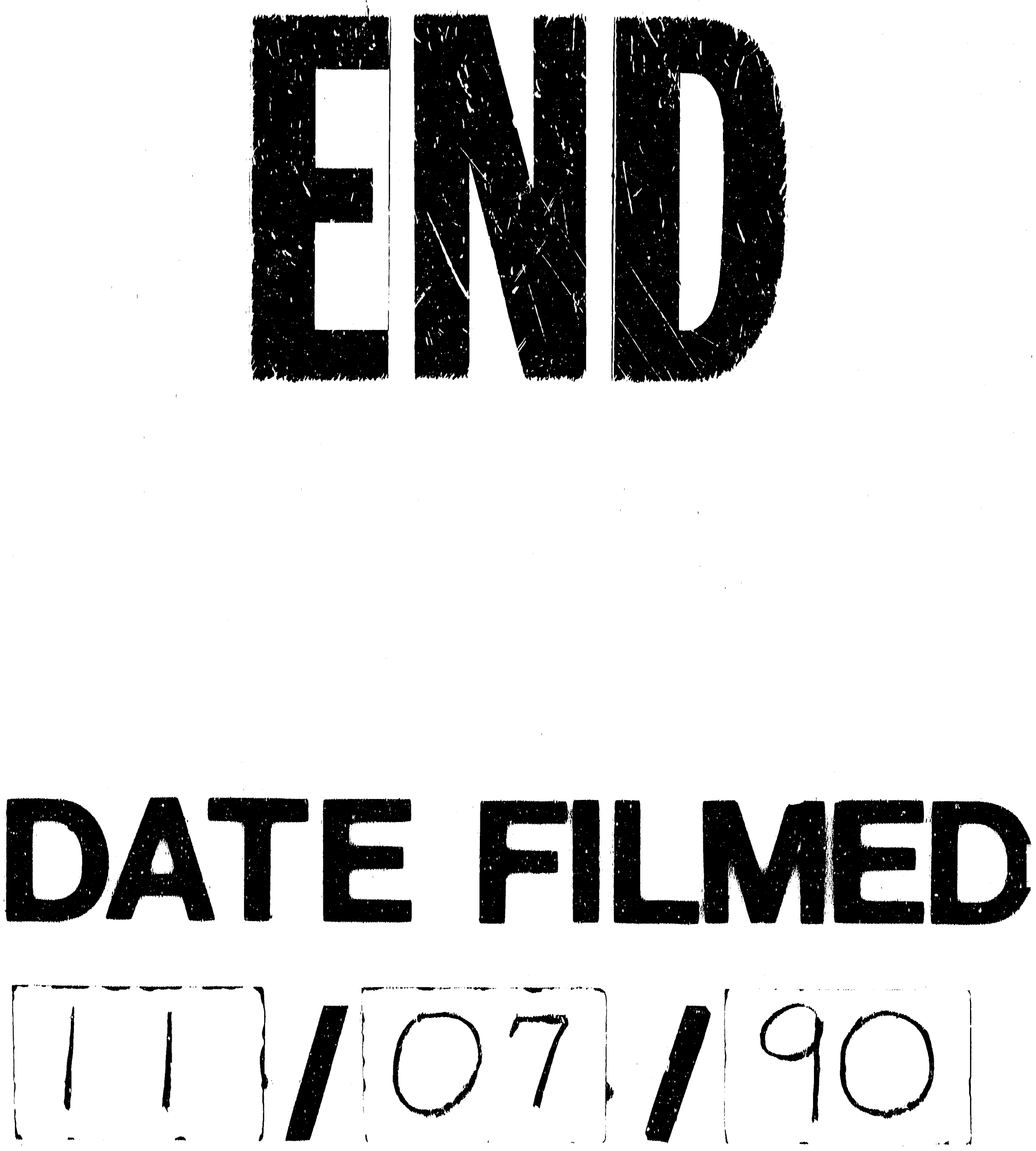